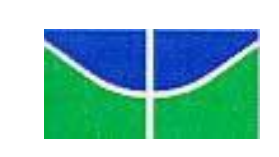

UNIVERSIDADE DE BRASÍLIA

FACULDADE DE DIREITO

DEBORAH B. CAIXETA

\title{
CONTRATOS ASSOCIATIVOS: CARACTERÍSTICAS E RELEVÂNCIA PARA O DIREITO CONCORRENCIAL DAS ESTRUTURAS
}

BRASÍLIA

2015 
UNIVERSIDADE DE BRASÍLIA

FACULDADE DE DIREITO

\title{
CONTRATOS ASSOCIATIVOS: CARACTERÍSTICAS E RELEVÂNCIA PARA O DIREITO CONCORRENCIAL DAS ESTRUTURAS
}

\author{
Autora: Deborah Batista Caixeta \\ Orientadora: Prof. Dr. Ana Frazão Vieira de Melo
}

Dissertação apresentada como requisito parcial à obtenção do grau de Mestre, no Programa de Pós-Graduação da Faculdade de Direito da Universidade de Brasília, linha de pesquisa “Globalização, Transformações do Direito e Ordem Econômica”.

Brasília, 05 de maio de 2015. 


\section{FOLHA DE APROVAÇÃ̃}

\section{DEBORAH BATISTA CAIXETA}

Contratos Associativos: características e relevância para o direito concorrencial das estruturas.

Dissertação apresentada como requisito parcial à obtenção do grau de Mestre, no Programa de Pós-Graduação da Faculdade de Direito da Universidade de Brasília, linha de pesquisa “Globalização, Transformações do Direito e Ordem Econômica”.

Brasília, 05 de maio de 2015.

\section{Banca Examinadora}

Prof.: Ana Frazão Vieira de Melo

(Orientadora-Presidente)

\begin{tabular}{c}
\hline $\begin{array}{c}\text { Prof.: Vinícius Marques de Carvalho } \\
\text { (Membro) }\end{array}$ \\
\hline Prof.: Marcio Iorio Aranha \\
(Membro) \\
\hline Prof.: Othon de Azevedo Lopes \\
(Suplente)
\end{tabular}


Aos meus amados pais, Alberto e Maria Helena, e irmã, Thaís, pelo inestimável apoio dado a minha formação pessoal e acadêmica e por terem me ensinado que nenhum sonho é grande o bastante que não possa ser alcançado. 


\section{AGRADECIMENTOS}

Aos meus pais, Alberto e Maria Helena, cúmplices e eternos amigos, agradeço pelo amor e pelo apoio dado a todos os meus projetos.

Primeiramente, devo enorme agradecimento a Professora e também chefe Ana Frazão que demonstrou generosidade e, sobretudo, paciência para compreender e orientar a confusão de ideias desta autora. 0 apoio e a orientação prestados foram inestimáveis e essências para a realização do presente trabalho.

Também agradeço às companheiras e amigas do CADE - Tati Britto e Ana Rafaela Medeiros - por terem criado um ambiente de trabalho extraordinário e, muitas vezes, por terem aliviado a minha carga de responsabilidades; uma ajuda sem a qual esta dissertação não poderia ter sido escrita.

À Hortênsia Medina não só pela amizade e companheirismos nos mais distintos ramos, agradeço também pela ajuda inestimável prestada durante o período de produção da dissertação.

Por fim, agradeço ao meu marido, Jose Andres, pelo constante estímulo e por todo suporte emocional dado no enfrentamento deste desafio. Sem dúvida, seu amor foi essencial para me dar força em continuar e não desistir diante de inúmeras pressões pelas quais passei durante esse período. 


\section{RESUMO}

O controle preventivo do antitruste procura impedir a formação de estruturas de mercado que podem alterar as relações de concorrência e favorecer a concentração ou a formação indevida de poder econômico. Duas são as formas de estruturação do poder econômico que estão sujeitas a este controle: as concentrações tradicionais e as "concentrações por cooperação". As concentrações por cooperação podem assumir distintas formas legais, sendo três delas de especial relevância para aplicação da Lei n. 12.529/2011: os consórcios, as joint ventures e os contratos associativos. O objeto do presente estudo centra-se na figura dos contratos associativos, procurando fixar um conteúdo típico dessa modalidade contratual principalmente numa lógica de compreensão geral de tipos de relações negociais - que possa servir de diretriz prática para a racionalização da aplicação do direito concorrencial aos casos concretos, principalmente no que toca aos critérios de notificação destes contratos e seu enquadramento nas hipóteses elencadas no artigo 90 da Lei n. 12.529/2011. Na busca da sua compreensão, economistas, principalmente aqueles ligados à Teoria da Organização Industrial, construíram importante instrumental de análise para assimilar a função que os contratos associativos assumem no atual cenário econômico. O ponto de partida da análise é, portanto, tentar compreender os contratos associativos, enquanto estruturas que correspondem à "terceira-via", a partir de suas diferenças com as formas extremas de organização da atividade empresarial: o mercado e a empresa. Para tanto, o primeiro capítulo procura delimitar o objeto de incidência do controle preventivo do antitruste. O segundo capítulo aborda uma dimensão do estudo compreendida na denominada economia industrial, que se mostra relevante para compreender a função que os contratos de cooperação interempresarial assumem no atual cenário econômico. As formas de "concentração por cooperação" serão estudadas no terceiro capítulo, procurando identificar o núcleo próprio dos contatos associativos, enquanto estruturas que correspondem à "terceira-via". Por fim, o último capítulo traz uma abordagem geral sobre a Resolução $\mathrm{n}^{\circ} 10$ de 2014, recentemente editada pelo CADE, que trata dos critérios de identificação e notificação dos contratos associativos ao controle preventivo. $\mathrm{O}$ intuito final do trabalho é poder contribuir para a compreensão e o aperfeiçoamento do controle preventivo que vem sendo conduzido pelo CADE no que diz respeito aos contratos associativos, principalmente em razão dos critérios fixados pela Resolução, que ainda estão longe de trazer parâmetros claros e objetivos que permitam a identificação desses contratos.

Palavras-chaves: Direito da Concorrência. Controle concorrencial das estruturas. Concentração por cooperação. Contratos associativos. CADE. 


\begin{abstract}
The preventive control of antitrust seeks to prevent the formation of market structures that can alter the competitive relationship and promote concentration or improper training of economic power. There are two ways of structuring the economic power that are subject to this control: the traditional concentrations and "concentrations by cooperation." Concentrations by cooperation can take different legal forms, three of them of particular relevance to the application of Brazilian Antitrust Law No. 12.529/2011: consortium, joint ventures and associative contracts. This study focuses on associative contracts, seeking to fix a typical content of this type of contract - especially in logic of general understanding of business types of relationships - that can serve as a practical guideline for streamlining the application of competition law. In this regard, economists, especially those related to the Theory of Industrial Organization, built important instrumental analysis to understand the function that associative contracts take in the current economic scenario. The analysis starting point is therefore try to understand associative contracts while structures that correspond to the "thirdway" between the extreme forms of business activity organization: the market and the firm. Thus, the first chapter seeks to define the object of incidence of antitrust preventive control. The second chapter covers a dimension of the study comprised the so-called industrial economies, which seem to be relevant for understanding the role that cooperation contracts take the current economic scenario. The forms of "concentration by cooperation" will be studied in the third chapter, trying to identify the very core of the associative contacts, while structures that consist on the "third-way" between the extreme forms of business activity organization: the market and the firm. Finally, the last chapter provides a general approach on Resolution No. 10 of 2014, recently published by CADE, which deals with the identification and notification criteria of associative contracts to structural control. The ultimate aim of the work is to contribute to the understanding and improvement of the preventive control that is being conducted by CADE with respect to associative contracts, mainly due to the criteria established by the Resolution, which are still far from bringing clear and objective parameters to identifying these contracts.
\end{abstract}

Key-words: Antitrut Law. Structural control of economic power. Concentration by cooperation. Associative contracts. CADE. 


\section{SUMÁRIO}

1. PARTICULARIDADES NA IDENTIFICAÇÃO DE OPERAÇõES EMPRESARIAIS SUJEITAS AO CONTROLE PREVENTIVO DO DIREITO CONCORRENCIAL......................... 5 1.1. A INDETERMINAÇÃo NORMATIVA DO CONTROLE PREVENTIVO A PARTIR DA EXPERIÊNCIA

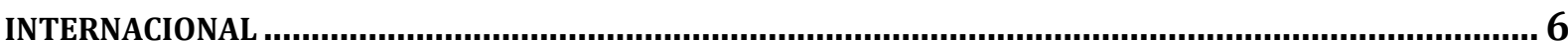

1.2. FUNDAMENTOS ECONÔMICOS DO CONTROLE PREVENTIVO ……............................................. 9

1.3. FUNDAMENTOS JURÍDICOS DO CONTROLE PREVENTIVO NO BRASIL ……..................................12

1.3.1. DO CONCEITO DE ATO DE CONCENTRAÇÃO ................................................................................16

1.3.2. O PAPEL DA AUTORIDADE ANTITRUSTE NA DELIMITAÇÃO DO OBJETO DO CONTROLE CONCORRENCIAL DAS ESTRUTURAS.

2. DESAFIOS CONTEMPORÂNEOS DO ANTITRUSTE - A “TERCEIRA VIA" ENTRE

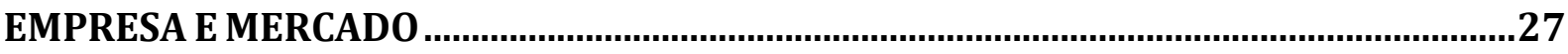

2.1. ConTRIBUIÇõES DA TEORIA DA ORGANIZAÇÃo EMPRESARIAL …..........................................27

2.2. UMA NOVA REALIDADE PARA O SISTEMA DE CONTROLE PREVENTIVO.......................................39

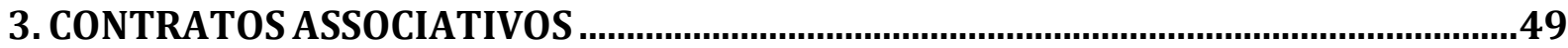

3.1. FORMAS DE "CONCENTRAÇÃO POR COOPERAÇÃO" .........................................................50

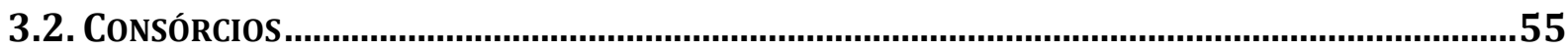

3.3. JOINT VENTURES SOCIETÁRIAS E CONTRATUAIS.................................................................56

3.4. UMA TENTATIVA DE DELIMITAÇÃo DO NÚCLEO PRÓPRIO DOS CONTRATOS ASSOCIATIVOS.........62

3.4.1. RELAÇÕES CONTRATUAIS E AS FORMAS DE ORGANIZAÇÃO DA ATIVIDADE EMPRESARIAL ......................62

3.4.2. CONTRATOS ASSOCIATIVOS PARA FINS DE APLICAÇÃO DA LEI N.12.529/11.......................................67

4. AS REGRAS DEFINIDAS PELO CADE PARA NOTIFICAÇÃO DE CONTRATOS

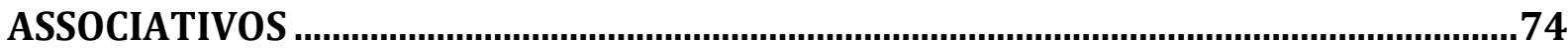

4.1. RESOLUÇÃo CADE № 10 DE 04 DE NOVEMBRO DE 2014 ……..........................................75

4.1.1. DO REQUISITO TEMPO.................................................................................................................77

4.1.2. OBJETO CONTRATUAL, DEFINIÇÃO DE MERCADO RELEVANTE E MARKET SHARE …………….............79

4.1.3. CLÁUSULA DE EXCLUSIVIDADE E COMPARTILHAMENTO DE RECEITAS E PREJUÍZOS .............................91

CONCLUSÃO

REFERÊNCIAS ...............................................................................................................104 


\section{INTRODUÇÃO}

O direito da concorrência tem como objeto o controle do poder econômico, o que pode ocorrer tanto pelo controle dos comportamentos, como pelo controle das estruturas.

O primeiro tem por intuito sancionar e regular o exercício abusivo do poder econômico já detido ou buscado ilegitimamente pelo agente por meio da conduta. Isso significa que a sua forma é "prioritariamente repressiva". Já o segundo tem por objeto impedir a formação, o aumento ou a consolidação de poder econômico, o que se dá de forma "prioritariamente preventiva". ${ }^{1}$

O controle preventivo, objeto do presente estudo, procura impedir a formação de estruturas de mercado que podem alterar as relações de concorrência e favorecer a concentração ou a formação indevida de poder econômico. Isso porque, como explicam as teorias microeconômicas sobre a racionalidade do agente, é alta a probabilidade de o poder econômico ser utilizado de forma abusiva por aquele que o detenha.

Ainda sobre esta perspectiva, duas são as formas de estruturação do poder econômico que estão sujeitas ao controle preventivo: as concentrações tradicionais e as concentrações por cooperação. Muitas críticas, no entanto, são endereçadas à sujeição dos acordos de cooperação ao controle preventivo, uma vez que, dentro dessa modalidade, é difícil traçar uma linha exata que distinga os atos ordinários empregados pelas empresas no curso normal do negócio, daqueles atos que de fato tem relevância para o direito da concorrência.

Analisando a realidade brasileira, referida controvérsia está atualmente presente na necessidade de notificação dos contratos associativos ao controle preventivo exercido pelo Conselho Administrativo de Defesa Econômica - CADE, conforme previsto no artigo 90 da Lei de Defesa da Concorrência brasileira - Lei n. 12.529/2011. A controvérsia existe especialmente porque não há uma definição clara no ordenamento jurídico do que seriam tais contratos e quais deles de fato possuem relevância concorrencial - um trabalho que recentemente coube ao CADE fazer por meio da edição da Resolução n. 10 de 2014. Tal conceituação, contudo, não foi acompanhada de maior reflexão sobre as especificidades dos

\footnotetext{
${ }^{1}$ Frazão (2015a, p. 8) utiliza o termo "prioritariamente”, buscando chamar atenção para a função dissuasória do controle de condutas.
} 
contratos associativos que deveriam torná-los objeto de controle preventivo do direito concorrencial. A presente pesquisa busca preencher tal lacuna.

O objetivo do presente estudo é, portanto, apresentar uma caracterização da figura dos contratos associativos, procurando fixar um conteúdo típico dessa modalidade contratual - principalmente numa lógica de compreensão geral de tipos de relações negociais - que possa servir de diretriz prática para a racionalização da aplicação do direito concorrencial aos casos concretos, principalmente no que toca aos critérios de notificação destes contratos e seu enquadramento nas hipóteses elencadas no artigo 90 da Lei n. 12.529/2011.

A pesquisa está organizada da seguinte forma. O primeiro capítulo procura delimitar o objeto de incidência do controle preventivo do antitruste. A Lei n. 12.529/2011 parece limitar o controle preventivo à existência de um ato de concentração, restringindo as hipóteses de notificação de operações quando delas decorram (i) fusão entre empresas; (ii) aquisição de participação societária ou controle por diversas formas; (iii) incorporação de empresas e (iv) celebração de contratos associativos, consórcios ou joint ventures. Nesta linha, o conceito de ato de concentração assume relevância na aplicação do dispositivo legal, o que torna necessária, portanto, a sua compreensão.

O primeiro capítulo procura ainda destacar algumas particularidades que marcam o controle preventivo de estruturas: i) a indeterminação conceitual de elementos normativos necessários para a implementação do controle preventivo; ii) a interdisciplinaridade entre direito e economia existente no direito da concorrência; e iii) o papel fundamental da autoridade antitruste na delimitação do objeto de incidência do controle preventivo por meio de metodologias e critérios que assegurem transparência, consistência e coerência na execução da lei. A partir dessas considerações, pretende-se mostrar que, independentemente da abertura conceitual das disposições legais, é preciso que o controle de estruturas seja seletivo e associado a preocupações concorrenciais relevantes, ainda mais porque o controle prévio instituído pela nova lei gera custos, tanto sob o ponto de vista das empresas quanto do ponto de vista da administração pública.

O segundo capítulo aborda uma dimensão do estudo compreendida na denominada economia industrial, que se mostra relevante na compreensão da visão estrutural do direito da concorrência - necessário à apreciação de estruturas de mercado nas quais se inserem as situações econômicas geradas pelos contratos associativos. 
O estudo do mercado e do comportamento dos agentes econômicos adquire importância nunca vista. Na busca da sua compreensão, os economistas, principalmente aqueles ligados à Teoria da Organização Industrial, construíram importante instrumental de análise para compreender a função que os contratos de cooperação interempresarial assumem no atual cenário econômico, servindo de suporte para a estruturação das relações de mercado, e, consequentemente, de incidência do direito concorrencial das estruturas.

As formas de "concentração por cooperação" serão estudadas no terceiro capítulo, procurando identificar o núcleo próprio dos contatos associativos. A primeira dificuldade relacionada ao assunto diz respeito à indefinição do que vem a ser um contrato associativo. Acordos de cooperação podem assumir distintas formas legais ${ }^{2}$, sendo três delas de especial relevância para aplicação da Lei n. 12.529/2011: os consórcios, as joint ventures e os contratos associativos. Desse modo, para se compreender o núcleo próprio dos contratos associativos, é importante traçar alguns aspectos distintivos em relação às demais formas de cooperação prevista no artigo 90, inciso IV da nova lei.

Apesar das dificuldades inerentes ao assunto, o ponto de partida da análise é tentar compreender os contratos associativos, enquanto estruturas que correspondem à "terceiravia", a partir de suas diferenças com as formas extremas de organização da atividade empresarial: o mercado - que se traduz nos contratos comutativos - e a empresa - que se traduz no poder hierárquico.

Por fim, o último capítulo traz uma abordagem geral sobre a Resolução $\mathrm{n}^{\circ} 10$ de 2014, recentemente editada pelo CADE, que trata dos critérios de identificação e notificação dos contratos associativos ao controle preventivo. O intuito nesse capítulo é demonstrar que a Resolução, além de não ser acompanhada de maior reflexão sobre as especificidades dos contratos associativos, está longe de trazer parâmetros claros e objetivos que permitem essa identificação. Isso significa que o CADE ainda tem um longo caminho na busca de métodos transparentes e adequados para a notificação de arranjos contratuais que envolvam estruturas cooperativas que fogem aos casos clássicos de concentração econômica.

O estudo procura definir o que são contratos associativos e em quais circunstâncias os referidos contratos podem ser identificados como objeto do controle concorrencial das estruturas. $\mathrm{O}$ intuito final do trabalho é poder contribuir para a compreensão

\footnotetext{
${ }^{2}$ Em sua obra Mariti e Smiley citam como exemplos de contratos cooperativos os consórcios licitantes e joint ventures. (1999, p. 279).
} 
e o aperfeiçoamento do controle preventivo que vem sendo conduzido pelo CADE desde a edição da Lei n. 12.529/2011, principalmente em razão da recente publicação da Resolução CADE $n^{\circ} 10$ de 2014, que trata dos critérios de notificação dos contratos associativos. 


\section{PARTICULARIDADES NA IDENTIFICAÇÃO DE OPERAÇÕES EMPRESARIAIS SUJEITAS AO CONTROLE PREVENTIVO DO DIREITO CONCORRENCIAL}

O presente capítulo dedica-se a examinar, a partir da experiência internacional, determinadas particularidades do direito da concorrência que vão repercutir na identificação de operações empresariais que serão objeto de controle preventivo da autoridade concorrencial.

Aqui serão analisados alguns aspectos distintivos do direito antitruste necessários para compreender o processo de construção de regras passíveis de implementação prática e determinantes para o processo de consolidação da jurisprudência no que toca a alguns aspectos do exercício do controle preventivo pela autoridade competente. Primeiramente, será examinado, a partir da experiência internacional, as características dos dispositivos legais que tratam do controle preventivo, normalmente marcados por indeterminação normativa e maleabilidade terminológica. A vagueza e a amplitude da técnica de redação empregada nos diplomas antitruste tornam extremamente difícil a delimitação apriorística de transações empresariais que deverão ser submetidas ao controle preventivo da autoridade, especialmente quando as operações envolvem atos que fogem à tradicional forma de estruturação do poder de mercado, as concentrações empresariais por meio de fusão ou aquisição de controle. Tal característica afeta os ideais de previsibilidade e de segurança jurídica tradicionalmente associados à intervenção estatal no livre exercício da atividade econômica.

Um segundo objeto de estudo desse capítulo é a influência histórica que a ciência econômica possui sobre o processo de tomada de decisão das autoridades competentes para aplicação das normas antitruste, que se faz notar tanto no direito antitruste norte-americano como no europeu.

A terceira parte do capítulo volta-se a examinar a experiência brasileira na implementação do controle preventivo, buscando fazer um cotejo entre os critérios estabelecidos pela antiga Lei n. 8.884/94 e as adaptações trazidas pela nova Lei n. $12.529 / 2011$.

O estudo procura demonstrar que uma característica central do direito antitruste preventivo é o amplo espaço decisório detido pelas autoridades públicas responsáveis pela sua implementação, a quem cabe a consolidação, pela via jurisprudencial e pela produção de 
normas infralegais, dos amplos e indeterminados comandos previstos nas legislações de defesa da concorrência.

Neste aspecto, procura-se destacar que, ainda que o processo decisório antitruste seja marcado por um ambiente de forte imprecisão, em razão da indisponibilidade de informações e da fragilidade do instrumento analítico empregado pelas autoridades em investigações concorrenciais, é preciso desenvolver uma política minimamente consistente de controle preventivo por parte do CADE, tema que será melhor desenvolvido no último capítulo desta dissertação.

\subsection{A INDETERMINAÇÃo NORMATIVA Do CONTROLE PREVENTIVO A PARTIR DA EXPERIÊNCIA INTERNACIONAL}

Uma das características mais marcantes na experiência internacional no controle de estruturas diz respeito à amplitude conceitual de expressões legais usadas na identificação das operações empresariais sujeitas ao controle estrutural. Não obstante, independentemente da maleabilidade terminológica que abre margem para inúmeras interpretações, uma coisa é certa: o sistema preventivo de controle de estruturas tem por objeto impedir a formação ou a concentração do poder econômico adquirido por meio de processos externos, isto é, que não ocorrem por meio do crescimento natural da empresa.

Nos Estados Unidos, por exemplo, as leis concorrenciais são notadamente curtas e imprecisas, como bem observa Herbert Hovenkamp (Hovenkamp 2008, p. 77). A Seção 7 do Clayton Act, com as emendas trazidas pelo Hart-Scott-Rodino (HSR) Act, fixa os critérios de notificação de operações empresariais e estabelece que estarão sujeitas ao reexame, por parte da Federal Trade Commission e do Departamento de Justiça, as transações empresariais que afetem o comércio nos Estados Unidos e que possam "reduzir substancialmente a concorrência”. O principal diploma norte-americano, logo, proíbe a realização de qualquer fusão ou aquisição que possa reduzir substancialmente a concorrência ou criar monopólios.

A técnica normativa empregada nas leis antitruste norte-americanas confere-lhes uma abrangência singular, permitindo que elas incidam sobre uma gama enorme de práticas empresariais. Como é da natureza de qualquer relação contratual estabelecer certa restrição concorrencial (Slot e Johnston 2006, p. 59), praticamente todo contrato empresarial poderia, $a$ priori, estar sujeito ao controle preventivo pela autoridade concorrencial. 
O HSR, ao trazer os critérios de notificação prévia dos acordos, estabelece que está sujeita ao controle preventivo qualquer transação que envolva fusão, aquisição de "bens" ou "títulos de voto", joint ventures e até mesmo "alguns tipos de interesses não corporativos desde que alcançado o requisito mínimo" (Kishor 2012, p.22). Isso significa que qualquer transação envolvendo ativos tangíveis ou intangíveis deveria ser revista pela autoridade em conformidade com o HRS Act ${ }^{3}$.

Em uma tentativa de restringir o alcance do controle preventivo, o Clayton Act 7A, 15 USC $\S 18$ a traz algumas hipóteses de isenções, entre as quais "aquisição de bens ou imóveis transferidos no curso ordinário do negócio" e, conforme as determinações da Comissão, “aquisição, transferências ou transações que não tenham capacidade de prejudicar a concorrência"4.

Por violação às leis antitruste entende-se, conforme disposições do Sherman Act, principal diploma concorrencial norte-americano e fundamento jurídico para controlar o abuso de poder econômico naquele país, (i) qualquer forma de contrato ou conspiração que possa restringir o comércio e (ii) qualquer tentativa de monopolização ilegítima do comércio.

Expressões como "tentativa de monopolização", "redução substancial da concorrência", "curso ordinário do negócio", "possibilidade de violar a lei antitruste”, podem ser aplicadas a uma variedade considerável de transações comerciais, o que dificulta qualquer definição a priori de operações empresariais que estariam de fato isentas do controle antitruste preventivo. Isso significa que, não obstante qualquer esforço da legislação norteamericana no sentido de restringir as hipóteses sujeitas ao controle preventivo, ela ainda apresenta falhas e um elevado grau de vagueza que não permite que o intérprete extraia de forma unívoca os critérios de identificação das transações comerciais que estariam sujeitas ao controle preventivo do direito concorrencial.

O Sherman Act não endereça questões específicas do enforcement antitruste, deixando em aberto a definição de termos centrais, tais como "redução substancial da concorrência” (Pitofsky 1979, 1060), dificultando, assim, a identificação de critérios claros e objetivos que permitam apontar as operações sujeitas ao controle preventivo. Todavia, Blackwell (1972, p. 14), ao analisar a política de enforcement da seção 7 do Clayton Act,

\footnotetext{
${ }^{3}$ O termo "ativos" não é definido pelo HRS, deste modo, as agências têm adotado uma definição mais ampla no sentido de que essa aquisição envolve tanto ativos tangíveis ou intangíveis. Isso significa que qualquer aquisição de direito exclusivo de patente deveria ser submetido ao controle preventivo (Kishor 2012).

${ }^{4}$ Clayton Act 7A, 15 USC $\S 18 \mathrm{a}$, subsection $(\mathrm{d})(2)(\mathrm{B})$.
} 
afirma que, ainda que as disposições sejam vagas, a política geral do Departamento de Justiça para fazer cumprir a Secção 7 é a preservação e promoção das "estruturas de mercado favoráveis à concorrência." Por isso, o principal impulso do programa de fiscalização do antitruste norte-americana não é dirigido a incidentes isolados ou intenção anticoncorrencial, mas a aquisições que alteram a composição elementar do mercado (Blackwell 1972, p. 14).

A indeterminação terminológica das leis antitruste é característica que também pode ser percebida no direito comunitário europeu. A abrangência dos dispositivos legais disciplinadores do controle antitruste de estruturas também se revela na enorme e variada gama de práticas empresariais por eles alcançada.

A regra geral insculpida no artigo 81 do Tratado da Comunidade Europeia declara serem incompatíveis com o mercado comum e proibidos todos os acordos, associações ou práticas concertadas entre empresas, que sejam susceptíveis de afetar o comércio entre os Estados-Membros e que tenham por objetivo ou efeito impedir, restringir ou falsear a concorrência no mercado comum. A União Europeia, ao tratar de suas regras de concorrência, não dispunha de um controle de estruturas preventivo. O Regulamento (CEE) n ${ }^{\circ}$ 4064/89 do Conselho, de 21 de Dezembro de 1989, relativo ao controle das operações de concentração de empresas permitiu desenvolver uma política comunitária neste domínio.

O Regulamento foi alterado de modo substancial várias vezes, porque a União Europeia entende ser conveniente, à luz da experiência adquirida, que se proceda à reformulação deste regulamento a fim de prever disposições adaptadas aos desafios do mercado.

Atualmente, o Regulamento $n^{\circ} 4064 / 89$ foi alterado pelo Regulamento CE $n^{\circ}$ $139 / 2004^{5}$, que trouxe disposições consideráveis principalmente sobre a submissão de cooperações econômicas ao controle preventivo de estruturas. De modo geral, é possível observar que a análise dessas operações envolve uma combinação de critérios jurídicos de apreciação de formas de coordenação de comportamentos empresariais, indutores de efeitos restritivos, com critérios de alterações da estrutura de concorrência em determinados mercados (Silva Morais 2006, p. 42).

É recorrente, no entanto, a observação acerca da dificuldade enfrentada pelos agentes econômicos para cumprir com a legislação concorrencial, dada a impossibilidade de

\footnotetext{
5 Regulamento CE no 139/2004 DO CONSELHO de 20 de Janeiro de 2004 relativo ao controlo das concentrações de empresas («Regulamento das concentrações comunitárias». Publicado no Jornal Oficial da União Europeia L 24/1 de 29.1.2004.
} 
se identificar orientações normativas coerentes, apesar dos esforços endereçados pelas autoridades concorrenciais em definir critérios de apreciação de operações de concentração econômicas (Elhauge 2003, p. 102).

Em se tratando do controle preventivo, a consequência dessa indeterminação normativa são ainda mais sensíveis. Sob o ponto de vista do administrado, a notificação de operações empresariais eleva os custos de transação das empresas em razão da demora na apreciação do casos, resulta no dispêndio de recurso desnecessário para submeter o ato ao controle estatal, além de ocasionar o engessamento da atividade empresarial, principalmente naquelas jurisdições onde o controle estrutural é feito de forma prévia, ou seja, antes da consumação o negócio. Já sob o ponto de vista da autoridade, a notificação de operações desnecessárias resulta em gasto de recursos públicos que poderiam ser utilizados na persecução de condutas e operações mais relevantes sob o aspecto concorrencial.

Do exposto, vê-se que os diplomas legais que fundam o controle antitruste de estruturas nos Estados Unidos e na Europa compartilham duas características centrais: a indeterminação terminológica quanto aos critérios de identificação de transações empresariais que devem ser submetidas ao controle preventivo e a necessidade de atuação da autoridade concorrencial no sentido de interpretar a norma, trazendo os critérios legais que melhor atendam aos objetivos perseguidos pelo antitruste. Com maior razão é a relevância do papel da autoridade na diferenciação entre operações empresariais que estão sujeitas ou não ao escrutínio concorrencial no âmbito do controle preventivo.

\subsection{FUNDAMENTOS ECONÔMICOS DO CONTROLE PREVENTIVO}

De acordo com o item anterior, as leis antitruste são marcadas por uma indeterminação conceitual dos elementos que caracterizam as transações empresariais submetidas ao controle prévio concorrencial. Este aspecto contribuiu para a histórica interdisciplinariedade entre o direito da concorrência e a ciência econômica uma vez que, na medida em que o texto legal se utiliza de vários conceitos econômicos sem defini-los, a ciência econômica passa então a preencher tal lacuna, fornecendo o instrumento teórico e analítico para a determinação do significado de muitas das amplas previsões legais do diploma concorrencial (Mendes 2013, p. 18).

A ciência econômica fornece, inclusive, fundamentos para compreender a própria função do controle preventivo que tradicionalmente encontrou amparo no paradigma da 
estrutura-conduta-desempenho (ECD). Segundo essa teoria, haveria uma relação causal direta entre a estrutura do mercado e a conduta da empresa, que, por sua vez, determinaria o seu desempenho produtivo. Isso significa que o controle preventivo se fundamenta na ideia de que a integração entre agentes econômicos pode resultar em uma estrutura de mercado mais concentrada e, consequentemente, gerar efeitos indesejáveis do ponto de vista concorrencial, tais como aumento de preço, redução da qualidade, colusão entre concorrentes, resultando na perda de bem-estar econômico ${ }^{6}$.

Deste modo, a estrutura concentrada do mercado, resultante do processo de integração empresarial, poderia levar a práticas anticoncorrenciais, uma vez que indústrias mais concentradas tendem naturalmente ao comportamento oligopolístico, diminuindo o desempenho industrial das empresas (Hovenkamp 2005, p. 42). Em outras palavras, significa dizer que, quanto maior for a concentração na oferta de determinado produto/serviço (estrutura), maior será a possibilidade de colusão ou de exercício unilateral de poder de mercado pelos os agentes econômicos (conduta) e, consequentemente, poderá ocorrer o aumento injustificado dos preços (desempenho) (Hovenkamp 2005, p. 42).

É justamente nesse aspecto que reside o fundamento econômico básico do controle preventivo do antitruste, de que o adequado funcionamento do mercado requer não apenas o controle de condutas, mas também uma atuação direta da autoridade na formação das estruturas, que se apresentam normalmente como a causa do problema. Isto é, segundo os fundamentos econômicos, é necessário que a autoridade atue no sentido de impedir a formação de estruturas empresariais que restrinjam indevidamente a livre concorrência, seja porque propiciam o exercício abusivo de poder econômico, adquirido ou reforçado em virtude da operação, seja porque facilitam a colusão ${ }^{7}$, motivo pelo qual devem ser evitadas excessivas concentrações em prol de estruturas de mercado mais pulverizadas.

O elemento central em torno do qual gira o fundamento econômico do controle preventivo é o exercício ilegítimo e abusivo do poder de mercado. "Poder de mercado" é uma expressão essencialmente econômica, definida como a capacidade de uma firma aumentar

\footnotetext{
6 O bem-estar econômico é verificado a partir de elementos que proporcionam maior nível de comodidade econômica e satisfação coletiva, determinado pela capacidade de acesso a bens, serviços e oportunidades econômicas geradas por atividades. No antitruste, é definida como a soma dos excedentes do consumidor e do produtor (Motta, 2004, p. 42).

${ }^{7}$ A atuação preventiva se mostra ainda mais relevante diante das dificuldades normalmente enfrentadas pela autoridade para se identificar e punir condutas anticompetitivas por meio do controle sancionatório. Sobre as dificuldades normalmente enfrentadas no controle de condutas vide Mendes (2013).
} 
preços acima do nível competitivo - valor de referência - de forma rentável (Motta, 2004, p. $40-41)^{8}$.

Igualmente, esclarece a ciência econômica que o poder de mercado resultante da integração empresarial pode ser exercido tanto de forma unilateral como de forma coordenada. A redução da concentração de mercado reduz as condições de rivalidade entre os concorrentes e cria um ambiente propício para que a empresa fusionada, normalmente que detém posição dominante, possa ditar unilateralmente as regras de concorrência, criando ou elevando artificialmente as barreiras à entrada ou até mesmo eliminando concorrentes já estabelecidos. Uma fusão pode ainda aumentar o risco de exercício de poder coordenado, pois, ao reduzir o número de players no mercado, pode gerar maior simetria de informações entre os concorrentes estabelecidos (Motta, 2004, p. 251), que passam de modo colusivo ou coordenado a extrair ilegitimamente benefícios do consumidor.

Desta forma, vê-se que as consequência negativas associadas ao exercício do poder de mercado dizem respeito à possibilidade de haver ineficiências alocativas e produtivas por parte da empresa que o detenha. Neste contexto, o controle preventivo assume tanta ou até maior relevância do que o controle de condutas, uma vez que se presta a evitar a formação ou a consolidação do poder de mercado, já que da prevenção no campo microeconômico podem derivar importantes efeitos positivos macroeconômicos (Salomão Filho 2013, p. 134). Neste sentido são, inclusive, as observações da Organização para Cooperação e Desenvolvimento Econômico - OCDE (2003, p.105) de que impedir que as empresas obtenham poder econômico é melhor do que tentar controlar o exercício desse poder uma vez que ele seja consolidado.

A despeito dos potenciais efeitos anticompetitivos decorrentes da concentração do mercado, a ciência econômica também contribui de forma considerável na identificação de eficiências que podem compensar positivamente o aumento do poder de mercado por parte das firmas integradas. Nesta linha são as principais contribuições da Escola de Chicago, que passou a destacar que a integração entre empresas pode gerar reduções de custos de produção, economias de escala e de escopo, diminuição de custos de transação, desenvolvimento de

\footnotetext{
${ }^{8}$ Poder de mercado pode também ser definido como a capacidade de determinado agente econômico de agir independentemente de seus concorrentes, estabelecer preços (pricemaker) e excluir competidores (definição apontada pela ex-Conselheira do CADE Lucia Helena Salgado no julgamento do AC no 84/96). Apesar das discussões terminológicas existentes, o presente estudo, para efeitos de simplificação, utiliza as expressões "poder de mercado", "poder econômico" e "posição dominante" como sinônimas.
} 
novas tecnologias, que assim podem gerar inúmeras eficiências, inclusive, menores preços e incrementos de qualidade nos produtos e serviços disponibilizados ao consumidor final.

Verifica-se, portanto, que as operações de concentração empresarial podem levar a resultados tanto eficientes quanto ineficientes. Alguns doutrinadores têm observado que as teorias e ideias econômicas muitas vezes são empregadas pelas autoridades concorrenciais de forma bastante desestruturada e fragmentada, com o intuito de se buscar a explicação mais persuasiva para o caso analisado, sem maiores considerações do contexto global em que a decisão seria tomada (J. E. Lopatka e Page 2004, p. 632). Assim, com maior rigor, o controle preventivo a ser exercido pela autoridade deve ser minimamente cuidadoso para que não leve ao engessamento desnecessário da economia e, ao mesmo tempo, não seja negligente com aquelas operações que, aparentemente podem ser benéficas, mas na realidade podem trazer sérias consequências ao ambiente concorrencial.

Igualmente, é preciso considerar que o direito concorrencial volta-se a regular fenômenos de natureza eminentemente econômica (Eilmansberger 2005, p. 138). Desta forma, a correta aplicação das normas concorrenciais demanda uma compreensão adequada do objeto regulado, a partir das considerações que a ciência econômica tem deste objeto.

Dado que o conhecimento sobre os impactos que determinadas práticas empresariais podem causar no mercado não é estático, desenvolvimentos observados na teoria da organização industrial trazem sempre consigo a possibilidade de transformação concomitante no direito da concorrência (Baker 2002, p. 68). Aliás, como se verá no próximo capítulo, esse ramo da ciência econômica traz elementos relevantes que precisam ser considerados na definição de contratos associativos que se pretende buscar no presente trabalho.

\subsection{FUNDAMENTOS JURÍDICOS DO CONTROLE PREVENTIVO NO BRASIL}

Como visto na parte inicial deste capítulo, é característica comum aos ordenamentos internacionais de direito da concorrência a opção por uma legislação conceitualmente indeterminada. Tal característica remete à própria natureza desse direito que, enquanto instrumento de regulação da atividade empresarial, deve estar apto a lidar com as transformações das relações empresariais (Hovenkamp 2008, p. 7). Daí porque as disposições legais a respeito do controle preventivo são tão abrangentes, uma vez que são inúmeras as formas de levar à formação ou consolidação de poder de mercado, razão pela qual o direito 
concorrencial precisa acompanhar a multiformidade e a evolução constante do fenômeno empresarial (Frazão 2015, p. 1).

Verificando o ordenamento brasileiro, nota-se que a Lei n. 8.884/94, pelas disposições do caput do artigo 54, que tinha como inspiração o artigo 81 do Tratado de Roma supracitado, ampliava sobremaneira o objeto de incidência do controle preventivo e trazia algumas hipóteses exemplificativas no $\S 3^{\circ}$, assim transcrito:

Art. 54. Os atos, sob qualquer forma manifestados, que possam limitar ou de qualquer forma prejudicar a livre concorrência, ou resultar na dominação de mercados relevantes de bens ou serviços, deverão ser submetidos à apreciação do CADE. (Revogado pela Lei n. 12.529, de 2011).

$[\ldots]$

$\S 3^{\circ}$ Incluem-se nos atos de que trata o caput aqueles que visem a qualquer forma de concentração econômica, seja através de fusão ou incorporação de empresas, constituição de sociedade para exercer o controle de empresas ou qualquer forma de agrupamento societário, que implique participação de empresa ou grupo de empresas resultante em vinte por cento de um mercado relevante, ou em que qualquer dos participantes tenha registrado faturamento bruto anual no último balanço equivalente a R\$ 400.000.000,00 (quatrocentos milhões de reais). (Redação dada pela Medida Provisória $\mathrm{n}^{\circ}$ 1.950-70, de 2000)

A opção do legislador nacional na redação da Lei n. 8.884/94 claramente denota a preocupação de não se predefinir os vários conceitos essenciais ao desenvolvimento do controle preventivo, já que isso poderia limitar o alcance e a efetividade da política de defesa da concorrência. Consequentemente, o controle preventivo antitruste poderia incidir sobre inúmeros tipos de práticas empresariais, podendo, inclusive, resultar no controle de toda forma de relação contratual, já que qualquer contrato pode implicar, em certa medida, limitação a concorrência (Chang, Evans e Schmalensee 2003, p. 12) ${ }^{9}$.

O controle de estruturas instituído pelo artigo 54 da antiga Lei era alvo de inúmeras críticas em razão da insegurança jurídica gerada pela escassez de parâmetros para a identificação dos atos sujeitos à notificação obrigatória. A tentativa de definição de critérios claros encontrava dificuldades justamente porque a análise do CADE se dava a partir da existência ou não de um potencial efeito anticompetitivo.

A Lei n. 12.529/2011, que revogou a Lei n. 8.884/94, trouxe, no entanto, novos parâmetros de delimitação do objeto de incidência do controle preventivo do CADE. O artigo

\footnotetext{
${ }^{9}$ Segundo R. H. Coase, "the contract is on whereby the factor, for a certain remunaration (which may be fixed or fluctuating), agrees to obey the directions of an entrepreneur whithin certain limits. [...] Whitin these limits, he can therefore direct the other factors of production". (1999, p. 44).
} 
88 do novo diploma concorrencial parece limitar o controle preventivo a existência de um ato de concentração, restringindo, no artigo 90, as hipóteses de notificação de operações quando constituam (i) fusão entre empresas; (ii) aquisição de participação societária ou controle por diversas formas; (iii) incorporação de empresas e (iv) celebração de contratos associativos, consórcios ou joint ventures:

Art. 88. Serão submetidos ao Cade pelas partes envolvidas na operação os atos de concentração econômica em que, cumulativamente:

$[\ldots]$

Art. 90. Para os efeitos do art. 88 desta Lei, realiza-se um ato de concentração quando:

I - 2 (duas) ou mais empresas anteriormente independentes se fundem;

II - 1 (uma) ou mais empresas adquirem, direta ou indiretamente, por compra ou permuta de ações, quotas, títulos ou valores mobiliários conversíveis em ações, ou ativos, tangíveis ou intangíveis, por via contratual ou por qualquer outro meio ou forma, o controle ou partes de uma ou outras empresas;

III - 1 (uma) ou mais empresas incorporam outra ou outras empresas; ou

IV - 2 (duas) ou mais empresas celebram contrato associativo, consórcio ou joint venture.

Parágrafo único. Não serão considerados atos de concentração, para os efeitos do disposto no art. 88 desta Lei, os descritos no inciso IV do caput, quando destinados às licitações promovidas pela administração pública direta e indireta e aos contratos delas decorrentes.

A partir da enumeração de hipóteses de ato de concentração, é possível notar um traço em comum entre todas elas. As situações elencadas no artigo 90 se baseiam na "ideia da reunião, aumento ou transferência de ativos empresariais ou de poder de comando ou gestão, este último traduzido pelo controle societário, tal como definido na Lei das Sociedades Anônimas, ou por outras formas de influência na condução dos negócios empresariais" ${ }^{10}$.

Os três primeiros incisos do artigo 90 referem-se às tradicionais formas de concentração empresarial, em relação às quais não há maiores dúvidas quanto ao aumento de poder empresarial. "As discussões persistem em relação às hipóteses de incidência do inciso IV, até por retratarem fenômenos mais recentes de organização empresarial, em relação aos quais a reflexão e a experiência jurídica ainda são incipientes" ${ }^{11}$. É possível observar, nestes

\footnotetext{
${ }^{10}$ Voto vogal da Conselheira Ana Frazão nos ACs Monsanto: Ato de Concentração no 08012.002870/2012-38. Requerentes: Monsanto do Brasil Ltda. e Syngenta Proteção de Cultivos Ltda. Relator: Marcos Paulo Veríssimo. Ato de Concentração nº 08012.006706/2012-08 Requerentes: Monsanto do Brasil Ltda. e Nidera Sementes Ltda. Relator: Alessandro Octaviani. Ato de Concentração no 08012.003898/2012-34 Requerentes: Monsanto do Brasil Ltda. e Cooperativa Central de Pesquisa Agrícola Relator: Alessandro Octaviani Ato de Concentração ${ }^{\circ}$ 08012.003937/2012-01 Requerentes: Monsanto do Brasil Ltda. e Don Mario Sementes Ltda. Relator: Alessandro Octaviani. Todos julgados em 28.08.2013. Para efeitos de simplificação, os Atos de Concentração serão mencionados ao logo do trabalho como "ACs Monsanto".

${ }^{11}$ Idem, p. 7.
} 
casos, uma preocupação do legislador de lidar com formas de organização da atividade empresarial que não dependem necessariamente de vínculos societários, mas que podem ser constituídas por meros vínculos contratuais.

Com efeito, como se verá no capítulo seguinte, a atual conjectura econômica é marcada por um aumento crescente de contratos que, não se ajustando às hipóteses clássicas de concentração, têm levado a efeitos semelhantes no que diz respeito à agregação de poder empresarial das contratantes - que, segundo Ana Frazão (2015), pode se dar tanto em razão do aumento do poder de comando ou gestão empresarial ou pela mera possibilidade de influência na condução dos negócios empresariais de ambas ou de uma das contratantes. Trata-se, desta forma, de uma tentativa do legislador de lidar não somente com a “fragmentação do controle empresarial” (Frazão 2015), mas também com novas estratégias empresariais de formação, consolidação ou exercício de poder de mercado (unilateral ou coordenado) prejudicial à concorrência, e que podem ser evitadas por meio do controle preventivo do antitruste.

A necessidade de se evitar o exercício de poder de mercado por meio dessas novas estruturas de organização empresarial justifica, inclusive, a ausência de definições exatas de algumas expressões necessárias para a aplicação da Lei, tal como se dá com o conceito de contratos associativos.

Ocorre que contratos associativos, em sua concepção mais ampla, podem abranger qualquer contrato de longa duração estabelecido entre empresas. Isso significa que contratos que versam desde o fornecimento de matéria-prima - um tipo de relação que se dá no curso normal dos negócios -, até mesmo a formação de cartéis - que se trata de uma estrutura reprimida pelo controle de condutas ou controle repressivo exercido pelo CADE -, poderiam estar sujeitos ao controle preventivo. Esse, contudo, não é o objetivo do controle de estruturas concorrenciais.

Uma definição latíssima de contratos associativos pode causar efeitos adversos, tanto sob o aspecto do administrado quanto do ponto de vista da administração pública, caso se mantenha sua incidência sobre uma ampla gama de negócios jurídicos. Não se enquadra nas pretensões da autoridade causar o engessamento da atividade econômica, nem tão pouco dispender recursos públicos desnecessários para controlar operações empresariais que não representam qualquer risco para o ambiente concorrencial. 
Daí o papel fundamental do CADE em estabelecer os limites de incidência dos artigos 88 e 90 da Lei n. 12.529/2011, traçando critérios claros e objetivos a respeito das formas contratuais que deverão ser submetidas ao controle preventivo, até mesmo porque o controle prévio instituído pela nova lei gera altos custos econômicos, na medida em que impossibilita a eficácia imediata de todas as operações que estão sujeitas a ele.

A atuação preventiva, já em evidência na Lei n. 8.884/94, vem ganhando destaque em relação à atuação sancionatória do antitruste desde a entrada em vigor da Lei $n$. 12.529/2011, inclusive pela instituição do controle prévio das transações comerciais. Não obstante, como visto anteriormente, os artigos 88 e 90 do novo diploma trouxeram critérios mais rígidos a respeito da incidência do controle de estruturas: o alcance do faturamento mínimo legal e a existência de um ato de concentração. Isso significa que a autoridade deve ser cautelosa na identificação dos atos que devem ser obrigatoriamente notificados, uma vez que o controle preventivo não pode abranger qualquer tipo de relação empresarial, inclusive porque a nova lei trouxe critérios mais específicos para a incidência do controle de estruturas, sendo um deles a existência de um "ato de concentração". Nesta linha, o conceito de "ato de concentração" assume relevância na aplicação do dispositivo legal, o que torna necessária a sua compreensão.

\subsubsection{DO CONCEITO DE ATO DE CONCENTRAÇÃO}

Concentração econômica, em seu sentido amplo, compreende todos os processos que levam ao domínio do mercado por um pequeno grupo de empresas, designadamente a integração vertical ou horizontal em uma só empresa ou grupo disciplinado de empresas, mas também outras ações que criem fatores de monopólio sobre quotas do mercado ou se traduzam em entendimentos restritivos da concorrência (Lima Pinheiro 2003, p. 234).

Numa acepção mais restrita, entende-se por concentração de empresas ações que conduzam á consolidação de uma pluralidade de empresas numa única unidade econômica organizada, o que implica a perda da individualidade econômica e organizativa dos ativos e demais recursos relacionados à uma certa atividade desenvolvida para a realização de um fim ou complexo de fins comuns (Lima Pinheiro 2003, p. 236).

Para Salomão Filho (2007, p. 285), um ato de concentração ocorre quando duas empresas podem ser consideradas como um único agente do ponto de vista econômico para 
todas as operações por elas realizadas ${ }^{12}$. Não basta a existência de um mero acordo, é necessário uma mudança estrutural duradoura na empresa que permita uma ampla uniformidade econômica. Do contrário, a uniformização de certos comportamentos ou a realização conjunta de apenas algumas atividades configuraria uma cooperação empresarial.

De modo geral, segundo o conceito tradicional, ato de concentração se dá sob bases societárias, enquanto a cooperação empresarial se dá por meio de acordo. Ato de concentração é, portanto, definido por quatro aspectos: (i) alteração na estrutura organizacional das empresas envolvidas, (ii) alteração não-transitória, (iii) formação de uma unidade de comando e (iv) uniformização em todos os aspectos da atividade da empresa controlada.

A concepção de ato de concentração apontada por Salomão Filho remete, desta forma, a alterações nas estruturas internas da empresa que podem estar relacionadas ao exercício do poder de controle, que pode se dar, segundo ensinamentos do direito societário, tanto pela formação de uma nova pessoa jurídica (fusão e incorporação) ou pela aquisição ou alteração do controle da sociedade. Deste modo, a concentração operacionaliza-se por vínculos societários estabelecidos entre sociedades que, embora mantenham a sua autonomia jurídica, criam um novo centro decisório na medida em que as sociedades relacionadas perdem total ou parcialmente a sua autonomia econômica, estando elas submetidas a um controle ou direção comum ou compartilhada. Nesse sentido, explica Ana Frazão (2015a) que não é sem razão que as sociedades pertencentes ao mesmo grupo podem ser consideradas como uma só empresa: a empresa plurissocietária.

Essa situação encontra, inclusive, respaldo na definição de "empresa""13 desenvolvida por Coase (1999, p. 44), segundo o qual a empresa surge quando a direção dos recursos, estabelecida dentro do limite dos contratos, se torna dependente de uma das empresas relacionadas. Nesta linha, a empresa consiste em um sistema de relacionamento que

\footnotetext{
${ }^{12} \mathrm{O}$ conceito defendido por Calixto Salomão se apresenta bastante restritivo, uma vez que desconsidera as formas de concentrações parciais, modalidades em que justamente se enquadram as formas de "concentração por cooperação". Deste modo, a concepção desenvolvida pelo autor é contrária à ideia de contratos associativos como atos de concentração, uma vez que tais contratos são exemplos de "concentração por cooperação", como será explorado no terceiro capítulo.

13 A palavra "empresa" é utilizada pelo Direito principalmente com cinco significados: (i) como sinônimo de "empresário" - pessoa singular ou coletiva que exerce atividade econômica mediante uma organização empresarial ; (ii) no sentido de "empresário coletivo", referindo apenas a pessoa coletiva que exerce atividade econômica mediante uma organização empresarial; (iii) enquanto determina forma de organização dos fatores de produção na realização de uma atividade econômica; (iv) no sentido de atividade empresarial e (v) no sentido de "estabelecimento", entendido como conjunto de elementos patrimoniais afectos à actividade empresarial. (Lima Pinheiro 2003, p. 27).
} 
passa a existir quando a direção dos recursos se torna dependente de um centro único de tomada de decisão estabelecido seja em conjunto pelas firmas relacionadas ou determinado por apenas uma delas. Ou ainda, no sentido atribuído por Luis Lima Pinheiro (2003, p. 29), quando resulta na formação de uma "unidade de ação econômica organizada".

Adverte Salomão Filho, no entanto, que a definição de poder de controle, que atrai a incidência do controle concorrencial, não se trata, propriamente, da definição trabalhada no direito societário, até mesmo porque a preocupação do direito antitruste não é a sociedade controlada, mas os efeitos da dominação societária no mercado (Salomão Filho 2013, p. 306). O poder de controle societário confere ao seu detentor a capacidade de influenciar as decisões mercadológicas da sociedade. Todavia, não é pressuposto necessário para que tal influência exista (Chinaglia 2010, p. 418).

Com efeito, a despreocupação do direito concorrencial com as formas ${ }^{14}$ encontra suporte na utilização de conceitos mais amplos, menos societários e mais econômicos, de vinculação entre as empresas, que permitem a formação de um centro único de decisões, tais como influência dominante e influência relevante do ponto de vista concorrencial.

O conceito de influência dominante surge, desta forma, no intuito de demonstrar que as concentrações econômicas não estão estruturadas somente sob a tradicional forma de coligação e participação societária, mas também podem ser estruturadas sob a forma contratual (Salomão Filho 2013, p. 316). Já o conceito de influência relevante foi desenvolvido para demonstrar que estruturas societárias podem configurar formas de cooperação entre empresas e não propriamente atos de concentração.

A noção de influência dominante surgiu no direito societário alemão para abarcar hipóteses em que o controle da empresa não decorre da existência de posição majoritária interna, podendo abranger situações de controle gerencial e o externo, inclusive, controle externo de fato. Fala-se em controle externo meramente de fato nos casos em que não há atribuição formal de poder de controle a seu titular (Salomão Filho, 2013, p. 312).

\footnotetext{
${ }^{14}$ Ana Frazão (2015a, p.10) destaca que um dos importantes importantes princípios do direito da concorrência é o da irrelevância das formas, segundo o qual, sempre que as partes chegarem ao resultado de constituírem um ente econômico autônomo, tal operação deve ser considerada um ato de concentração, independentemente das formas jurídicas utilizadas para se chegar a tais resultados. No mesmo sentido, Hovenkamp (1999, p. 491) entende que na atualidade os meios pelos quais as fusões (mergers) ocorrem são irrelevantes para efeitos de sua licitude diante da legislação antitruste.
} 
Não obstante, como bem explica a Conselheira Ana Frazão ${ }^{15}$, a mera possibilidade de haver o controle externo não é suficiente para tornar determinada operação um ato de concentração. Isso porque, ao contrário das demais formas de controle, o controle externo é extremamente casuístico e insuscetível de presunções ou constatações apriorísticas. Pode, inclusive, decorrer até mesmo de contratos celebrados no curso normal dos negócios, tais como empréstimo ou fornecimento ${ }^{16}$.

Nesta linha também reside o entendimento de Calixto Salomão (2013) de que para o exercício de influência duradoura é preciso que o poder tenha algum substrato estrutural. Segundo o doutrinador, a influência dominante concorrencial deve ser estável, constante e abrangente. Não basta o poder de determinar atos isolados de comércio; a capacidade de influir no planejamento da empresa deve ser ampla e possuir bases estruturais e estáveis que lhe permitam perdurar no tempo. Isso significa que o controle externo deve se traduzir em presença dominante nos órgãos encarregados das decisões sobre as matérias fundamentais para o planejamento empresarial ou, então, em poder de decidir sobre essas matérias. Pouco espaço sobra, portanto, para o controle meramente de fato, que é por natureza incerto na intensidade e na duração.

Isso não significa que a influência dominante tenha somente natureza societária em que exista controle majoritário ou minoritário que revista dos requisitos legais necessários para fazer presumir a permanência no poder -, pode também apresentar natureza contratual. Dentre as formas contratuais Salomão Filho cita: (i) qualquer contrato que dê a seu titular o direito de gerir o empreendimento; (ii) contrato que confere ao seu titular a possibilidade de eleger membro da Administração; (iii) contratos que atribuem a seus titulares direitos muito superiores àqueles necessários a atingir seus objetivos primários.

Este último critério, em especial, assume relevância para o direito concorrencial na identificação de concentrações que se dão a partir de acordos de cooperação, quando os contratos atribuem aos seus titulares direitos muito superiores àqueles necessários a atingir seus objetivos primários. O critério procura identificar, desta forma, se uma determinada transação permitirá que uma empresa adquira a capacidade de exercer algum tipo de influência sobre a outra empresa previamente independente.

\footnotetext{
${ }^{15}$ Voto-vogal da Conselheira Ana Frazão nos ACs Monsanto.

${ }^{16}$ Voto do Relator Conselheiro Alessandro Octaviani nos ACs Monsanto.
} 
Comparato e Salomão Filho (2014, p. 462) reconhecem tais hipóteses como negócios jurídicos indiretos, nas quais se busca um terceiro efeito ulterior ao declarado pelas partes, numa tentativa de poder influir no planejamento empresarial da outra empresa.

O entendimento se justifica porque a capacidade de determinar comportamentos econômicos alheios, em condições diversas daquilo que ocorreria em regime concorrencial puro, constitui, segundo Sergio Bruna (2001, p. 173), a essência do poder econômico. Desse modo, ainda que não se possa identificar um poder de comando ou controle societário no caso concreto, a mera constatação de que determinado negócio jurídico pode outorgar ao agente econômico a possibilidade de influenciar, de forma relevante, os processos de tomada de decisão de um fornecedor, cliente ou rival é suficiente para que tal evento seja analisado sob o prisma do controle preventivo do antitruste (Chinaglia 2010, p. 413).

O conceito de influência relevante do ponto de vista concorrencial, por sua vez, procura lidar com situações em que a estrutura societária permita presumir que a formação interna da vontade na empresa "participada" seria de tal maneira influenciada, ainda que não determinada, de modo que poderia se presumir a cooperação entre elas. O conceito de influência relevante procura, desta forma, lidar com as situações de fragmentação do poder de controle (Frazão 2015, p. 2), que podem ocasionar efeitos adversos à concorrência. Dentre as possíveis formas de influência relevante do ponto de vista concorrencial, cita-se: (i) poder de veto na sociedade, que pode decorrer tanto de participação societária quanto de contrato; (ii) existência de relevante participação no capital votante da sociedade; (iii) interlocking directorates, (iv) participações societárias minoritárias que asseguram contatos estratégicos entre as sociedades e acesso a informações concorrencialmente sensíveis (Frazão 2015, p. 2).

De modo mais abrangente, influência relevante faz-se presente quando é possível presumir um comportamento cooperativo entre as empresas, a partir da união dos centros decisórios em áreas específicas e estratégicas da empresa ${ }^{17}$. Não há, todavia, critérios objetivos que possam apontar a existência de influência relevante quando ela não decorra propriamente de um poder societário. Nessa linha, o Conselheiro Ricardo Cueva, no julgamento do $A C n^{\circ}$ 08012.010293/2004-48, indicou que a sua identificação poderia ser feita pelo exame, no caso concreto, (i) do interesse em intervir na atuação da empresa no mercado e (ii) pela possibilidade e efetividade dessa intervenção.

\footnotetext{
${ }^{17}$ Voto do Conselheiro Ricardo Cueva no AC no 08012.010293/2004-48. Requerentes: Ideiasnet S.A. e Flynet S.A. Relator:Luis Alberto Esteves. Julgado em 26.01.2006.
} 
A Comunidade Europeia adota um sistema semelhante. Segundo os termos do Regulamento CE $n^{\circ} 139 / 2004^{18}$ uma concentração ocorre quando uma operação resulta numa mudança duradoura de controle das empresas relacionadas, sendo que esse controle poderia se dar pelas seguintes formas:

O controle decorre dos direitos, contratos ou outros meios que conferem, isoladamente ou em conjunto, e tendo em conta as circunstâncias de facto [sic] e de direito, a possibilidade de exercer uma influência determinante sobre uma empresa e, nomeadamente: a) Direitos de propriedade ou de uso ou de fruição sobre a totalidade ou parte dos activos [sic] de uma empresa; b) Direitos ou contratos que conferem uma influência determinante na composição, nas deliberações ou nas decisões dos órgãos de uma empresa. ${ }^{19}$

O Relatório da International Competition Network (ICN) sobre a definição de "ato de concentração" dispõe de modo geral que o controle de concentrações diz respeito a operações que resultem em uma associação de empresas e ativos previamente independentes, combinados de forma que envolva uma mudança duradoura na estrutura das empresas ou na propriedade dos ativos envolvidos na operação. ${ }^{20}$ No mesmo estudo, há o reconhecimento de que para distinguir ato de concentração dos meros contratos de colaboração - que controlados de forma repressiva -, deve-se levar em consideração o nível de integração econômica entre as partes e a duração da associação.

Trata-se, portanto, de hipóteses que resultam em alguma alteração na forma de controle de ativos tangíveis e intangíveis relevantes à concorrência - ativos cuja transferência implicar, concomitantemente, (i) na perda da capacidade competitiva da empresa que os fornece e (ii) no ganho sensível de capacidade produtiva por parte da empresa que os adquire -, bem como incentivos para o seu uso, o que igualmente se daria pela alteração duradoura na propriedade ou combinações de ativos anteriormente independentes.

Sendo assim, ato de concentração é uma operação de crescimento externo por meio de relações interempresariais que alteram a estrutura do mercado, na medida em que estabelecem formas de integração econômica e resultam na formação de um novo ente econômico (Frazão 2015a, p. 01). Tais estruturas poderiam ser objetivamente apreensíveis

18 Regulamento CE no 139/2004 DO CONSELHO de 20 de Janeiro de 2004 relativo ao controlo das concentrações de empresas («Regulamento das concentrações comunitárias». Publicado no Jornal Oficial da União Europeia L 24/1 de 29.1.2004.

${ }^{19}$ Disposições do Artigo 3 ${ }^{\circ}$, item 2 do Regulamento (CE) $n^{\circ}$ 139/2004.

${ }^{20}$ Relatório ICN sobre a "Definição de Ato de Concentração". http://www.internationalcompetitionnetwork.org/uploads/library/doc327.pdf. 
pela (i) formação de uma empresa comum, ou (ii) reunião, aumento ou transferência de ativos empresariais ou (iii) exercício de poder de comando ou gestão, entendendo-se este último como qualquer forma de influência na condução dos negócios empresariais de qualquer das empresas relacionadas.

1.3.2. O PAPEL DA AUTORIDADE ANTITRUSTE NA DELIMITAÇÃO DO OBJETO DO CONTROLE CONCORRENCIAL DAS ESTRUTURAS

Um estudo da Organização para Cooperação e Desenvolvimento Econômico $\mathrm{OCDE}^{21}$ demonstrou que as definições do que constitui ato de concentração (merger transaction) podem ser baseadas em critérios objetivos, critérios numéricos ou, até mesmo, em critérios econômicos, os quais procuram alinhar a definição de uma operação de concentração de forma mais estreita com a possibilidade desta operação poder resultar problemas concorrenciais. Cada abordagem tem suas próprias vantagens e desvantagens. Todas elas são comumente usadas na análise de atos de concentração, e algumas jurisdições estrangeiras usam, inclusive, uma combinação de abordagens.

A adoção de critérios mais econômicos e consequencialistas está, nesta ordem, em consonância com o entendimento segundo o qual a definição de ato de concentração se refere propriamente aos efeitos de um ato no mercado relevante. Segundo as conclusões da OCDE, esse critério de definição tende a capturar os possíveis problemas concorrenciais mais diretamente do que critérios objetivos e, por isso, alcançam efetivamente transações mais problemáticas. Essa abordagem também explica como uma nova compreensão dos riscos substanciais associados a certo tipo de transação pode levar a pressões para mudar a definição do conceito de ato de concentração (“merger transaction"). Se um consenso é estabelecido no sentido de que certas transações potencialmente podem causar danos que antes não eram percebidos, é de se esperar que estas operações não sejam deixadas de fora do controle preventivo.

A delimitação do objeto de incidência do controle preventivo centrado no risco que as operações podem causar, apesar de, por um lado, alcançar as operações que de fato são preocupantes para o direito da concorrência, por outro lado, no entanto, requerem uma

\footnotetext{
${ }^{21}$ OECD. Definition of Transaction for the Purpose of Merger Control Review. 2013. http://www.oecd.org/daf/competition/Merger-control-review-2013.pdf
} 
interpretação mais específica dos casos reais. O critério pode criar mais incertezas e tornar o controle preventivo menos transparente (OCDE 2013, p.6).

Essa racionalidade, inclusive, era muito evidente no controle estrutural estabelecido pela antiga Lei n. 8.884/94, segundo a qual os atos sob qualquer forma manifestados, que pudessem limitar ou de qualquer forma prejudicar a livre concorrência, ou resultar na dominação de mercados relevantes de bens ou serviços, deveriam ser submetidos à apreciação do CADE.

O controle de estruturas instituído pelo artigo 54 da antiga Lei era alvo de inúmeras críticas em razão da insegurança jurídica gerada pela escassez de parâmetros para a identificação dos atos sujeitos à notificação obrigatória. A tentativa de definição de critérios claros encontrava dificuldades justamente porque a análise do CADE se dava a partir da existência ou não de um potencial efeito anticompetitivo.

A Lei n. 12.529/2011 parece não ter deixado margem a este tipo de discussão. Os artigos 88 e 90 do novo diploma procuraram endereçar parte das dificuldades enfrentadas no sistema anterior ao estabelecer requisitos mais específicos, quantitativos e qualitativos, de identificação das operações que estariam sujeitas ao controle preventivo, procurando parâmetros mais seguros para a definição das operações sujeitas ao controle, são eles: (i) um faturamento que atenda ao mínimo legal e (ii) a existência de um ato de concentração, restringindo as hipóteses de notificação à (i) fusão entre empresas; (ii) aquisição de participação societária ou controle por diversas formas; (iii) incorporação de empresas e (iv) celebração de contratos associativos, consórcios ou joint ventures.

É forçoso convir que o eventual risco de produção de efeitos anticompetitivos faz com que os contratos cooperativos possam ser considerados, por essa única razão, como atos de concentração; e de fato não são ${ }^{22}$. O risco de produção de efeitos competitivos pode ser, por si só, elemento justificador do controle de condutas, mas não do controle de estrutura, o qual está sujeito a filtros importantes - como o faturamento das empresas envolvidas e a existência de um ato de concentração (Frazão, 2015a) (Calixto, 2013).

\footnotetext{
${ }^{22}$ Segundo Ana Frazão (2015a, p. 09) "estão igualmente excluídos do âmbito do controle de estruturas contratos ou outras formas de relacionamento entre as partes que, embora possam levar a efeitos anticompetitivos, não consistem em um ato de concentração". Importante adiantar, neste ponto, que nem todo contrato cooperativo corresponde a um contrato associativo. Como será mais bem delineado no terceiro capítulo, podem estar enquadrados como contratos cooperativos qualquer contrato que estabelece uma relação de longa duração entre as partes. Já os contratos associativos, além de estabelecer uma relação duradoura entre as contratantes, também são necessariamente qualificados pela existência de um escopo em comum entre elas, e é justamente em razão deste aspecto que os contratos associativos são considerados modalidades de "concentração por cooperação".
} 
Como visto anteriormente, ato de concentração é uma operação de crescimento externo por meio de relações interempresariais que alteram a estrutura do mercado, na medida em que resultam da formação de um novo ente econômico.

Não obstante, o condicionamento dessa forma de controle à existência de um ato de concentração, especialmente em se tratando das hipóteses de notificação de acordos de cooperação, ainda enseja muitas dúvidas, dentre elas, a de que a identificação do "novo ente empresarial" na realidade não se apresenta como uma tarefa trivial na aplicação prática do conceito.

A distorção normativa criada pelo artigo 88 da Lei 12.529/2011, ao condicionar o controle preventivo à existência de um ato de concentração, acaba influenciando, indevidamente, a modelação de relações empresariais sujeitas ao controle preventivo principalmente aquelas que envolvem aspectos de cooperação - estabelecendo uma forma de controle menos em virtude dos seus méritos e eficácia intrínsecas e mais em função de preocupações relacionadas com mecanismos de subsunção em categorias ou conceitos de direito da concorrência, o que se revela contraditório quanto à persecução dos objetivos essenciais do direito da concorrência.

Ademais, a adoção de parâmetros formais de qualificação jurídica pode, com frequência, induzir as empresas a moldar, intencionalmente, o conteúdo dos seus acordos com vistas a afastar a subsunção dos mesmos em determinadas categorias conceptuais prédefinidas (Bork 1993, p. 69). Diante da impropriedade de um modelo conceptual de análise, a autoridade antitruste assume papel fundamental na determinação de critérios claros e objetivos, o qual, frisa-se, deve manter certa coerência e consistência a partir de elementos já observados na praxis decisória do órgão.

O "corte conceitual" escolhido pelo legislador ainda apresenta controvérsias, especialmente no que toca ao enquadramento dos contratos associativos neste conceito. Essa indeterminação transfere à autoridade o papel de definir os limites de incidência do controle preventivo do antitruste, traçando critérios rigorosos, claros e objetivos a fim de delimitar com precisão os contratos que devem estar sujeitos ao escrutínio antitruste e aqueles que podem ser consumados desde já, ainda que sujeitos ao posterior controle de condutas (Frazão, 2015a).

De modo geral, é possível notar, a partir da experiência internacional, que não há uma definição muito clara do que seja um ato de concentração. Isso porque a definição de um 
"ato de concentração" pode significar coisas diferentes, em diferentes regimes de apreciação das concentrações (OCDE 2013, p. 06) ${ }^{23}$. Entretanto, independentemente de como o sistema de controle preventivo tenha organizado o processo de notificação, um aspecto comum a todos os sistemas é a necessidade de definir, em um primeiro passo, que tipos de transação que consideram "adequadas" para o controle preventivo.

Neste sentido, diante da deficiência do conceito de ato de concentração, a identificação de critérios objetivos de notificação ganha especial relevância já que contribuem para uma maior efetividade, eficiência e transparência do sistema de controle preventivo antitruste. Os objetivos na identificação destes critérios normalmente estão relacionados a (i) alcançar o tipo certo de transações, e.g. aquelas que levam a alterações estruturais mais duradouras no mercado e que poderiam pôr em causa os objetivos da política concorrencial; (ii) evitar capturar muitas transações que normalmente não acarretam nenhum risco à concorrência ou que sejam mais adequadamente controlados por outros instrumentos do qual dispões o regime do direito concorrencial (e.g., controle de condutas); e (iii) definir, o máximo possível, testes ou critérios de análise que sejam transparentes, objetivos e claros, para determinar aquelas transações que estão sujeitas à fiscalização prévia da autoridade.

Veja, portanto, que a delimitação de critérios objetivos para o exercício do controle preventivo se mostra tão importante quanto às tentativas de conceituação de ato de concentração, que se apresenta falha diante de situações que não se enquadram propriamente neste conceito.

Não se defende aqui que o controle preventivo deve ser submetido a uma reflexão a respeito dos seus pressupostos básicos. Não obstante, mais do que um esforço em buscar conceituar "ato de concentração", a partir de novos conceitos que igualmente se mostrarão inaplicáveis na prática, cabe à autoridade antitruste identificar critérios claros e objetivos a partir dos quais é possível, ao menos, presumir a existência de uma concentração econômica.

Em outras palavras, o que se defende aqui é que definir critérios de notificação é tão importante quanto buscar uma conceituação de "ato de concentração", porque na prática, a implementação do que seria um "ato de concentração" se mostra mais complexa do que no

\footnotetext{
${ }^{23}$ Some countries use objective criteria and economic criteria side-byside so that, for example, acquisitions of a $25 \%$ interest or $50 \%$ interest in another firm; of "control" over another firm; of a significant competitive influence over another firm; and of all or substantial parts of the assets of another firm, are all considered merger transactions. Each of these thresholds can be independently applied to determine whether a transaction is considered a merger transaction (OCDE 2013).
} 
plano teórico. Deste modo, cabe à autoridade antitruste identificar critérios claros e objetivos a partir dos quais é possível, ao menos, presumir a existência de uma concentração econômica, aqui compreendida, a partir de um consenso geral dos doutrinadores brasileiros, como "formas de crescimento externo ou "artificial" do poder empresarial, que envolvem a união de esforços ou recursos de pelo menos dois agentes econômicos distintos que, de alguma maneira, tornar-se-ão uma unidade para efeitos econômicos” (Frazão 2015a, p. 09).

O papel desempenhado pela autoridade nessa questão é de suma importância para a adequada implementação da política de defesa da concorrência brasileira, principalmente no que toca a sujeição dos contratos associativos ao controle preventivo do antitruste.

Como será mais bem explorado no terceiro capítulo, tais contratos, além de não apresentarem uma definição legal, também fogem ao tradicional conceito de ato de concentração, representando um grande desafio para a autoridade na identificação de transações empresariais que se enquadram nessa modalidade contratual sujeita ao controle estrutural.

Ademais, o processo de formação das categorias normativas fundamentais do direito da concorrência abarca um processo complexo de juridicização de fenômenos econômicos, os quais, constantemente, adquirem nova natureza e deverão ser enquadrados por critérios jurídicos em interação permanente com a realidade subjacente. Deste modo, o capítulo seguinte procura abordar essa questão, trazendo o contexto econômico que justamente propicia a celebração de contratos associativos, representando assim novos desafios para a autoridade na definição de filtros adequados para a estruturação das hipóteses de incidência do controle preventivo antitruste em se tratando de contratos associativos. 


\section{DESAFIOS CONTEMPORÂNEOS DO ANTITRUSTE - A "TERCEIRA VIA" ENTRE EMPRESA E MERCADO}

Os contratos associativos vêm sendo objeto de progressivo interesse do direito concorrencial, na medida em que podem representar novas formas de conformação e exercício do poder de mercado que não dependem necessariamente de vínculos societários. Isso significa que tais contratos podem abranger elementos de concentração e de coordenação empresarial, desafiando a tradicional dicotomia associada à organização da atividade econômica entre empresa/mercado.

Deste modo, entender os possíveis efeitos destes contratos sobre a ordem econômica e sobre a organização da atividade empresarial é essencial para identificar as consequências jurídicas de tais acordos, e, consequentemente, para definir seu enquadramento nas hipóteses de incidência do controle preventivo antitruste. Neste propósito, a teoria da organização empresarial tem relevantes contribuições que permitem acessar as possíveis repercussões desses contratos sobre a atividade econômica.

\subsection{ConTribuiçõES DA TEORIA DA ORGANIZAÇÃo EMPRESARIAL}

A lógica do crescimento empresarial vem sendo constantemente transformada em função dos movimentos de aceleração e intensa globalização no cenário econômico, ensejando formas complexas de organização da atividade empresarial. O processo de crescimento tradicionalmente orientado pelos fenômenos de cooperação - caracterizado pela manutenção da individualidade própria de cada empresa - e de concentração - subjacente a perda dessa individualidade, hoje assume contornos ainda mais complexos, no que diz respeito ao tipo ou variedade de elementos sobre os quais se estrutura.

O estudo da organização industrial, em suas contribuições mais atuais, tem transcendido o seu antigo apego baseado em modelos "estrutura-conduta-performance", uma vez que o processo alternativo, atualmente observado, conjuga, numa ponderação variável, elementos característicos quer da coordenação, quer da concentração empresarial, determinando a estratégia de atuação da empresa do mercado.

O critério para a organização da atividade empresarial é normalmente assumido como estritamente instrumental para economizar custo. Essencialmente, a economia de custos se dá de duas formas: economizar em despesas de produção e economizar em custos de transação (Williamson 1999, p. 177). 
Em suma, as operações de mercado apresentam custos que podem ser poupados pela formação de uma organização empresarial que confere a direção de todos os recursos por meio de um único centro decisório (Coase 1999, p. 44). Nesta linha se baseia o entendimento de Coase, segundo o qual a formação da empresa se dá, primordialmente, em contraposição aos custos relacionados às transações de mercado. Isso significa que, a partir de uma análise de custos relacionados ao processo de comprar no mercado ou produzir internamente (make or buy), a empresa optaria por uma ou outra forma de organizar sua atividade: ou via transações de mercado ou via transações internas na própria empresa.

O objetivo de economizar é alcançado sobre o montante de custos relacionados à produção e à transação externa no mercado. Na medida em que os custos de transação são insignificantes em comparação com os custos de produção, comprar ao invés de produzir (make or buy process ) será normalmente o meio mais eficiente de organização da atividade empresarial $^{24}$. Assim, o custo em negociar e concluir diferentes contratos para cada transação comercial no mercado é sempre levado em consideração pela empresa.

Caso contrário, se os custos das transações externas são elevados em comparação com os custos relacionados à produção, a empresa optará por adaptar a sua organização para produzir internamente - seja por meio da adaptação da sua própria planta produtiva crescimento natural interno da empresa - ou por meio de operações de fusão e aquisição de outras empresas.

De fato, decisões relacionadas a make or buy são fundamentais para o planejamento da atividade empresarial, inclusive, para a determinação do próprio escopo da empresa (Buckley e Michie 1999, p. 2). Neste aspecto, no entanto, reside um importante avanço desde a Teoria da Firma de Ronald Coase, que tem como expressão máxima as críticas desenvolvidas por Richardson. Segundo este doutrinador, as opções tradicionais de produzir bens e serviços dentro da própria organização empresarial ou adquiri-los no mercado nem sempre levará a arranjos organizacionais adequados para a performance da empresa no mercado (Richardson, 1999).

\footnotetext{
${ }^{24}$ Luis Lima Pinheiro (2003, p. 49) explica que: "o preço de aquisição a outras empresas, especializadas na realização das diferentes atividades que integram este processo, é, em princípio, inferior aos custos da sua realização interna. Por conseguinte, a "exteriorização" de certas fases da cadeia de valor acrescentado é susceptível de proporcionar uma redução dos custos totais de produto final (processo de divisão de trabalho entre empresas)". Deste modo, as empresas tendem para um processo de especialização e aquisição exterior do resultado de atividades complementares. É justamente neste contexto em que a cooperação interempresarial ganha sobressalência.
} 
As profundas mutações qualitativas das condições de exercício da atividade econômica têm determinado as decisões relacionadas a make or buy, resultando em novas opções na conformação do processo jurídico de organização empresarial. No plano econômico, a progressiva internacionalização da atividade empresarial, combinada com a crescente tecnologia da informação e com a maior complexidade técnica do processo de produção, tem levado ao advento de modalidades mais flexíveis de organização da atividade, para fazer frente às necessidades impostas por essas transformações no cenário econômico. Richardson (1999, p. 60) se refere a um denso processo de cooperação e associação entre empresas que, contrariamente ao que normalmente se estuda sobre essas formas de relação interempresarial - interpretadas como manifestação de um desejo de restringir a concorrência por meio da fixação de preços ou divisão de mercado - na realidade, são formas alternativas de sobrevivência da empresa na atual conjuntura do mercado.

A pressão concorrencial de novos grupos empresariais especialmente aptos, em razão da sua flexibilidade estrutural, a adaptar seu comportamento comercial às condições de célere e contínua transformação dos processos produtivos tem relativizado o alcance das operações de concentração empresarial, impulsionando novas formas de organização da atividade, que buscam, além do encurtamento do ciclo de produção, também um processo de inovação empresarial permanente ${ }^{25}$.

Explica Luis Domingos Silva Morais (2006, p. 93) que problemas específicos de concorrência e particularidades na estrutura do mercado podem verificar-se no quadro de setores econômicos dominados por elementos de inovação e caracterizados pela contínua emergência de novos mercados relacionados. De modo sintomático, no contexto desses mercados, há uma progressiva substituição da titularidade exclusiva dos ativos e da unidade jurídica empresarial por elementos de associação ou cooperação empresarial, que se apresentam mais flexíveis. Os contratos associativos passam, então, a assumir papel fundamental como suporte de organização das atividades empresariais, na medida em que permitem às empresas criar novos arranjos combinando tanto aspectos favoráveis à estabilidade das relações como também elementos da flexibilidade do mercado, situando, desta forma na zona intermediária entre as formas extremas de organização da atividade empresarial: a empresa e o mercado.

\footnotetext{
${ }^{25}$ A diminuição do ciclo de vida dos produtos reduz o período de amortização e recuperção do investimento, principlamente daquele injetado em tecnologia. Indústrias marcadas por ritmo intenso de inovação tecnológica apresentam risco mais elevado e menos garantia de retorno dos investimentos (Lima Pinheiro 2003, p. 56).
} 
Assim, opta-se por uma terceira alternativa entre produzir ou simplesmente comprar (make or buy), rompendo com a tradicional dicotomia proposta por Ronald Coase de que a organização da atividade econômica se dá somente nas formas puras de empresa ou de mercado. Isto é, de que a organização empresarial se dá somente segundo uma relação de autoridade no âmbito da empresa ou segundo transações consensuais no mercado (Hart 199, p. 202).

A organização da atividade econômica na forma de "puro mercado" é marcada pela flexibilidade das relações econômicas e pela possibilidade de coordenação dos agentes do mercado, diante da independência e autonomia deles. A organização da atividade econômica na forma de "pura empresa", por sua vez, caracteriza-se pela hierarquia de comando $^{26}$, o que poderia ser comparado a uma relação existente entre mestre/servo ou empregado/empregador (Coase 1999, p. 53). Segundo a concepção coasiana, a opção por uma ou por outra forma de organização decorreria dos custos de transação que cada uma envolveria, ou seja, os custos de realizar uma transação no mercado ao invés de realizá-la no interior da empresa. Tais custos resultam das incertezas do mercado e abrangem desde os preços até a natureza e características do produto fornecido.

Daí a crítica de Ana Frazão (2015) no sentido de que a teoria de Ronald Coase acaba menosprezando as diversas gradações e combinações entre as opções extremas relacionadas ao processo de make or buy, já que parte de uma premissa reducionista de que a decisão do agente econômico é polarizada pela empresa ou pelo mercado.

É justamente nesta linha em que são desenvolvidas as críticas de Richardson $(1999$, p. 59) à teoria coasiana. O autor entende que a teoria ignora a existência de uma grande espécie de atividades industriais que são relevantes para compreender as formas de cooperação empresarial, que se situariam numa zona intermediária entres as duas formas extremas propostas por Coase de organização da atividade econômica - a empresa, onde se estabelece a coordenação dirigida das atividades ${ }^{27}$, e o mercado, onde se estabelece a coordenação espontânea e o livre mecanismo de preços. Richardson (1999, p. 59) assim compreende que o mercado e a empresa não são propriamente termos contraditórios, mas sim

\footnotetext{
${ }^{26}$ Por isso Ana Frazão (2015) entende que os grupos societários podem ser considerados uma só empresa - a empresa plurissocietária - desde que sujeitos a apenas um poder de controle ou direção.

27 Ana Frazão (2015) destaca, inclusive, a possibilidade de um movimento contínuo entre essas duas formas extremas de organização da atividade econômica, a exemplo das formas de cooperação de mercado em que um dos contratantes se encontra em posição de dependência econômica do outro. Neste caso, estar-se-ia diante de uma hipótese de relação de mercado com aspectos da direção empresarial.
} 
pontos extremos de um contínuo movimento entre situações de "mercado puro" ("pure market”) e de "empresa pura" ( "pure firm"), em que há vários estágios intermediários, o que o autor define como "firm like markets" ou "markets like firm".

Nesse contexto de transformações econômicas, que desperta a necessidade de estruturas organizacionais mais flexíveis que as empresas, porém mais estáveis ${ }^{28}$ que as relações de mercado, as alianças contratuais interempresariais, em que há uma colaboração sem necessariamente haver a criação de uma nova instituição, tornam-se ideais para administrar os riscos relacionados à incerteza do mercado, compartilhar os custos de investimentos de larga escala e injetar inovações em negócios empresarias já amadurecidos.

Luís Domingos Silva Morais (2006, p. 181) aponta as motivações mais recorrentes relacionadas a este processo de desagregação empresarial, e, consequentemente, ao desenvolvimento da "terceira-via" entre empresa e mercado. A primeira diz respeito à necessidade de acompanhar as inovações técnicas ao nível de produção industrial, que muitas vezes conjugam recursos complementares de diversas fontes. Uma economia caracterizada por produtos com ciclos de vida mais curtos, fatores produtivos extremamente dinâmicos e voláteis, ligados a formas de conhecimento especializado, requer formas de associação empresarial que permitam acompanhar essa evolução, principalmente o acesso a direitos de propriedade intelectual, sem que isso resulte na perda da individualidade própria de cada empresa.

Outra finalidade do processo de associação empresarial diz respeito à redução dos riscos financeiros relacionados a atividades empresariais tradicionalmente caracterizadas por fatores aleatórios, tal como sucede com pesquisas na área de petróleo, construção de obras públicas e atividades normalmente relacionadas à tecnologia avançada.

A aliança interempresarial pode ainda ter por intuito alcançar projetos de internacionalização de empresa, o que normalmente sofre entraves por conta de regulações nacionais; ou também permitir a formação de uma extensa rede de distribuição e escoamento de produtos.

Essa nova forma de organização industrial surge, principalmente, em decorrência da crescente influência da internet e das tecnologias de informação no processo produtivo

\footnotetext{
${ }^{28}$ Segundo Richardson (1999, p. 61) o requisito da estabilidade é importante por duas razões: "it is necessary,in the first place, to induce sub-contractors to assume the risks inherent in a rather narrow specialisation in skills and equipment; and, secondly, it permits continuing co-operation between those concerned in the development of spcifications, processes and desing".
} 
empresarial, impondo novas condições ao ambiente concorrencial entre elas, o que resulta em um processo de desagregação vertical e a troca de mecanismos administrativos internos por substitutos de mercado. Miles e Snow (1999, p. 429) apontam como evidências desse movimento o surgimento de redes dinâmicas (dynamic network), cujas formas organizacionais decorrem de combinações de estratégias, estruturas e processos gerenciais em resposta às mutações e complexidades das condições competitivas na atual conjuntura.

Sendo assim, a alternativa de produzir internamente não se limita necessariamente a comprar o insumo no mercado. Três são as possíveis alternativas: (i) organizar a atividade internamente; (ii) recorrer a transações individuais no mercado ou (iii) desenvolver acordos de cooperação entre uma ou mais empresas, que seria propriamente uma forma intermediária de organização (Mariti e Smiley 1999, p. 278). Deste modo, alternativamente às formas extremas de organização, há uma "terceira-via" às decisões de "make-or-buy" - a qual se dá normalmente pela simples contratação pontual do serviço no mercado - , que é criar uma rede (network) de relações estáveis de cooperação que procura incluir, dentre outros, fornecedores e distribuidores de diversos elementos que integram a cadeia produtiva.

O desenvolvimento desta "terceira-via" foi definido por Imai e Itami (1999, p. 293-317) como um processo de interpenetração entre empresa e mercado ou, ainda, como um processo de "quase integração vertical" (Blois 1999, p. 320-338) (Contractor e Lorange, 2002). De fato, muitas alianças surgem a partir de contribuições similares por cada parte relacionada. Não obstante, o atual processo de organização empresarial é marcado por alianças que, enquanto estabelecem relações de coprodução, parcerias em pesquisa e em serviços de administração e venda, são caracterizadas pela contribuição complementar entre partes relacionadas de elementos diferenciados da cadeia de produção ou distribuição de produtos. Ademais, esse processo é normalmente caracterizado por uma constante dependência econômica entre as empresas relacionadas, podendo gerar situações de influência concorrencial de uma sobre a outra (Blois 1999, p. 320-338).

Esse movimento de interpenetração entre empresa e mercado leva em consideração os inúmeros problemas relacionados às formas extremas de organização da atividade empresarial. Williamson (1999, p. 171) aponta, dentre eles que (i) nem todas as contingências do futuro podem ser antecipadas desde o início das atividades empresariais; (ii) as devidas adaptações para muitas das contingências não serão evidentes até que as circunstâncias se materializem; (iii) a contratação entre partes autônomas é normalmente 
difícil e gera grandes disputas, especialmente, considerando que o comportamento delas será sempre oportunístico.

Isso significa que ambos os contratante - comprador e fornecedor - estão estrategicamente situados para barganhar sobre a disposição de qualquer ganho incremental sempre que uma proposta de adaptação é feita pela outra parte. Isto é, mesmo que ambos tenham um interesse a longo prazo de alcançar a maximização do lucro de forma conjunta, cada um também tem interesse em apropriar-se o máximo de ganho que puder em cada ocasião que uma ou outra parte propõe adaptações nas relações comerciais. Assim, o oportunismo, entendido por Williamson (1999, p. 168) como "auto-interesse buscado com dolo", é um conceito central no estudo dos custos de transação.

Nesse cenário, uma nova forma de relação interempresarial é projetada no sentido de busca preservar a flexibilidade das transações comerciais, reduzindo os custos, mas, ao mesmo tempo, garantir padrões mínimos de estabilidade para lidar com as incertezas do mercado, principalmente com relação ao comportamento oportunístico das partes. Daí porque Willianson (1999, p. 192) reconhece a necessidade de estruturar modelos de governança contratuais em respostas aos aspectos fundamentais para a realização dos negócios justamente para evitar o oportunismo das firmas relacionadas ${ }^{29}$. Dessa forma, a estruturação das relações contratuais deve levar em consideração os aspectos da incerteza, da frequência com que a transação ocorre e do grau em que os investimentos podem ser considerados "idiosyncratic". 30

Com maior razão são as advertências de Hart (1989, p. 199-218) no sentido de que, em uma economia industrial caracterizada por consideráveis custos de transação e contratos incompletos, estabelecer direitos residuais de controle ex post se torna importante porque, em razão da sua influência sobre o uso dos ativos, tais direitos vão posteriormente afetar o poder de barganha das empresas relacionadas, bem como a divisão do excedente após

\footnotetext{
${ }^{29}$ Oliver Willianson (1999, p. 168) parte das seguintes premissas ao tratar dos contratos interempresariais neste contexto em que os custos de transações são determinantes para estabelecer os limites desta relação: (i) o oportunismo, entendido por ele como "auto-interesse buscado com dolo", é um conceito central no estudo de custos de transação, (ii) o oportunismo é especialmente importante em transações que envolvem investimentos em capital humano e físico, (iii) o eficiente processamento da informação é um conceito importante e relacionado aos dois aspectos anteriores e (iv) a avaliação dos custos de transação se dá por meio de instrumentos de comparação institucional.

${ }^{30}$ Explica Williamson (1999, p. 173) que "items that are unspecialized among users pose few hazerds, since buyers in these circumstances can easily turn to alternative sources, and suppliers can sell output intended for one order to other buyers without difficulty. Nonmarketability problems arise when the specific identity of the parties has important cost-bearing consequences. Transactions of this kind will be referred to as idiosyncratic."
} 
a relação comercial. Por isso, quando os contratos são incompletos, as fronteiras entre as firmas relacionadas são determinantes para fixar quem controlará e quem deterá cada ativo.

O reconhecimento de que o mundo é complexo, de que os contratos são incompletos e de que alguns contratos nunca serão realizados se não houver um mínimo de confiança no processo negocial ensejam, portanto, o desenho de estruturas de governança que permitam lidar com os problemas normalmente identificados no processo de organização de determinadas atividade empresariais.

Willianson (1999, p. 180) buscou identificar nas relações interempresariais estruturas de governança estabelecidas de acordo com o quadro institucional dentro do qual as transações comerciais são decididas.

A primeira delas, Governança de Mercado (Market Governance), é a principal forma de organização de transações não específicas, caracterizadas por contratos ocasionais e recorrentes. No tocante a mercados padronizados, acordos de compra e fornecimento alternativos são, presumivelmente, fáceis de encontrar no mercado. Isto é, as alternativas de mercado são tantas que protegem cada parte contra o comportamento oportunista da outra.

A Governança Trilateral (Trilateral Governance), por sua vez, está associada transações que podem apresentar idiossincrasias. O custo de oportunidade é mais baixo em transações alternativas, porque a troca de fornecedor resultaria em dificuldades excessivas na avaliação dos ativos, o que faz com que a governança de mercado deixe de ser suficiente para essas transações. Assim, para evitar as possíveis rupturas dessas transações, as partes precisam se valer da intervenção de uma terceira parte (third-party assistance).

Por fim, a Governança das Transações Específicas (Transaction-specific Governance), que assume especial relevância para o presente estudo, está associada a transações caracterizadas por elevada idiossincrasia e, concomitantemente, pela necessidade de se manter a continuidade e adaptabilidade em face das modificações futuras do mercado, uma vez que não se trata de relações ocasionais, mas de considerável duração a ser mantida entre as partes. Trata-se, portanto, de operações em que o oportunismo das partes gera elevados custos.

Para isso, as partes poderão optar tanto por estruturas bilaterais de governança, quando a autonomia entre as partes se mantém e estabelecem entre elas contratos meramente obrigacionais, ou por estruturas unificadas de governança, hipótese em que a transação é removida do mercado e passa a ser organizada no âmbito da própria empresa e sujeita, 
portanto, a uma relação de autoridade, resultando numa verdadeira integração vertical entre as empresas.

Como visto no item I.2, a ciência econômica influencia o direito concorrencial, principalmente por meio da compreensão dos efeitos que determinadas práticas causam no mercado. Deste modo, alterações no entendimento das consequências desta prática trazem, inexoravelmente, modificações na análise antitruste e, consequentemente, na aplicação da legislação concorrencial (Easterbrook, 1984, p. 10). Isso significa que a evolução do conhecimento econômico permite, sem qualquer alteração do texto legal, que determinadas relações comerciais antes consideradas ilegais sejam hoje aceitas (Anderson, Bolema e Geckil 2007, p. 5), bem como também podem demonstrar a existência de efeitos anticompetitivos de outras práticas que eram até então desconhecidos (Hovenkamp 2008, p. 38), demandando, portanto, maior rigor em relação a tais condutas.

Os desenvolvimentos recentes no campo da economia industrial - se por um lado ampliaram o conhecimento acerca dos possíveis efeitos econômicos de várias práticas empresariais, demonstrando a existência de efeitos tanto pró como anticompetitivos que eram ignorados - por outro, construíram um modelo de mercado muito mais complexo e confuso do que aqueles até então prevalecentes na prática antitruste (Hovenkamp 2002, p. 5).

Se, por um lado, essa tendência faz emergir grandes grupos societários caracterizados pela existência de uma organização centralizada em que as empresas multinacionais representam expressão mais evidente do fenômeno, por outro lado, faz acelerar processos de cooperação interempresarial de complexidade variável, podendo estes assumirem forma de verdadeira integração empresarial, desde que as empresas participantes não percam as bases mínimas da sua individualidade própria (Silva Morais 2006, p. 164), o que se conhece por uma "concentração por cooperação".

Em conformidade com item anterior, a necessidade de economizar custos de transação deflagrou um processo de desintegração empresarial, diluindo as fronteiras e a demarcação vertical entre as empresas. Esse processo rompeu com a tradicional dicotomia estabelecida entre as formas de organização da atividade empresarial por via da empresa ou do mercado, impostas pelas decisões de make or buy, abrindo espaço para o desenvolvimento de uma "terceira-via" caracterizada por mecanismos de cooperação empresarial, em especial, nas relações verticais que compõe a cadeia produtiva. 
O contexto econômico é, então, marcado por uma verdadeira "contratualização" dos processos produtivos, por meio da multiplicação de alianças externas e novas formas de governo contratual, recobrando uma posição dos contratos a um ponto intermediário entre a via do mercado e a via da integração empresarial (Willianson, 1999). Nesse cenário, vem se verificando a importância cada vez maior da desverticalização da atividade empresarial e da formação de sociedades em redes.

Mariti e Smiley promoveram um estudo a partir de uma base de dados de setenta operações de cooperação que ocorreram nos Estados Unidos no ano de 1980. A partir dessa base, identificaram as principais classificações de contratos de cooperação identificados àquela época: (i) contratos de transferência e troca de tecnologia, (ii) contratos de comercialização, (iii) contratos de compartilhamento de risco e (iv) contratos de economias de escala.

Os contratos de comercialização a que se refere o estudo são aqueles estabelecidos previamente para uma relação de longa duração entre as partes. Os contratos de economias de escala se referem a ambas as eficiências de produção e distribuição que precisam ser feitas em larga escala. Acordos do tipo compartilhamento de risco normalmente geralmente dispõem sobre a gestão da operação por um dos parceiros, enquanto o outro somente investe em capital e absorve o risco do negócio.

Sobre a indústria de alta tecnologia, é importante lembrar a advertência de Manuel Castells (2002, pp. 217-232), ao afirmar que uma das características da atual economia e sociedade de rede é precisamente a formação de novos modelos de estruturas empresariais a partir de redes multidirecionais e alianças estratégicas entre empresas de pequeno e médio porte que são controladas ou conformadas por grandes empresas de tecnologia, a partir do modelo de licenciamento e subcontratação da produção.

Não obstante, o campo dos acordos sobre tecnologia é uma das áreas da economia com maior déficit de análise. Segundo Richardson (1999, p. 62), esses acordos são baseados na licença ou pooling de patentes, mas de modo geral dispõem sobre troca de know-how por meio de transferência de informações, concessão de ferramentas e pessoal especializado. Frequentemente, essas acordos são mais permanentes do que uma simples transferência de licença e tendem a resultar na sujeição das partes à uma variedade de restrições sobre sua liberdade comercial (Mariti e Smiley 1999, p. 279). Afigura-se, por conseguinte, que a criação 
e a exploração de tecnologia por meio de transações de mercado - transações de licenças sempre haverá alguma medida de cooperação entre as partes.

Tecnologia nem sempre pode ser transferida simplesmente por meio da venda do direito de uso. Muito raramente a transferência de tecnologia é redutível a mera informação a ser passada adiante, isso porque normalmente consiste também no compartilhamento da experiência e das habilidades próprias da licenciante. Justamente por isso a transferência de tecnologia envolve um contínuo processo de cooperação, uma vez que o fornecimento não se reduz à licença, mas também envolve constante auxílio técnico entre as partes (Richardson 1999, p. 70). Transferência de tecnologia requer estruturas específicas de governança em razão dos requisitos especiais desse tipo de transação, em que a identidade das partes e a frequência da relação são aspectos claramente destacáveis (Williamson 1999, p. 180), razão pela qual alguns autores entendem que nestes casos, de uma forma ou de outra, parece provável que a concorrência será, em algum grau, reduzida (Richardson 1999, p. 70) (Mariti e Smiley 1999, p. 291).

Pesquisas nessa área têm demonstrado, portanto, que as novas estruturas empresarias não se baseiam propriamente na estrutura de organização de recursos humanos, mas, ao contrário, em transferência de direitos de propriedade (Hart 1999, p. 199), que podem inclusive alterar as relações de poder nestas estruturas.

Daí porque o Conselheiro do CADE, Alessandro Octaviani, ao julgar o caso Monsanto $^{31}$, entendeu que, para fins de configuração de ato de concentração, a formação de estruturas, principalmente em setores de alta tecnologia, dispensa muitas vezes as formas usuais de formação de sociedade ou contratos consensuais. Segundo o Conselheiro, nestas hipóteses, as estruturas poderiam ser formadas pela dependência da própria tecnologia, o que invariavelmente levaria a configuração de um controle empresarial $a b$ extra - controle externo -, no qual uma relação contratual de direito (por exemplo, um contrato de fornecimento de tecnologia sem exclusividade) pode significar de fato a direção dos negócios,

\footnotetext{
${ }^{31}$ Ato de Concentração no 08012.002870/2012-38. Requerentes: Monsanto do Brasil Ltda. e Syngenta Proteção de Cultivos Ltda. Relator: Marcos Paulo Veríssimo. Ato de Concentração n ${ }^{\circ}$ 08012.006706/2012-08 Requerentes: Monsanto do Brasil Ltda. e Nidera Sementes Ltda. Relator: Alessandro Octaviani. Ato de Concentração $\mathrm{n}^{\circ}$ 08012.003898/2012-34 Requerentes: Monsanto do Brasil Ltda. e Cooperativa Central de Pesquisa Agrícola Relator: Alessandro Octaviani Ato de Concentração nº 08012.003937/2012-01 Requerentes: Monsanto do Brasil Ltda. e Don Mario Sementes Ltda. Relator: Alessandro Octaviani. Todos julgados em 28.08.2013. Para efeitos de simplificação, os Atos de Concentração serão mencionados ao logo do trabalho como "AC Monsanto".
} 
não guardando a necessária correspondência com a forma jurídica expressa ou visível do negócio ${ }^{32}$.

É possível observar, portanto, que de um modo geral, o fenômeno da terceirização ou desintegração empresarial, tem manifestado uma preferência marcante pela adoção do esquema reticular, em que a vinculação entre as unidades empresariais já não se faz em termos de participação societária no capital, mas adota antes a forma de uma rede de contratos estáveis, o que tem alterado, inclusive, as relações de poder entre as empresas relacionadas. Alguns autores, no entanto, advertem que nem sempre as relações de comando estão expressas na forma contratual, ou seja, nem sempre os contratos de prestação de serviços ou de fornecimento contêm cláusulas expressas de comando, de subordinação ou de cooperação entre as empresas relacionadas. Na verdade, é da intensa dependência oriunda desses contratos que se origina o poder de comando. O controle, portanto, apesar de indiretamente baseado em um contrato, é de fato (Salomão Filho, 2013, p. 136).

Quanto a este aspecto, sobre a predominância do controle empresarial externo ou de fato sobre o interno, explica Comparato (1985, p. 135) que:

A grande novidade, sob o aspecto jurídico, é a de que esses grupos societários conservam, não obstante o abandono da técnica de participação acionária, uma estrutura de controle societário externo, sob a forma contratual. Ou seja, não se trata de um grupo de coordenação (Gleichordnungskonzern), como ocorre nos consórcios de empresas. Na rede grupal, a sociedade controladora, denominada broker, assume exclusivamente as funções de governo de um conjunto de outras empresas fornecedoras de componentes ou matérias-primas, fabricadoras de produtos acabados, pesquisadoras de novos produtos e novos mercados ou distribuidoras em diferentes mercados nacionais. É uma holding pura, sem participação no capital das controladas.

Importante notar que todas essas possíveis formas invariavelmente criam uma relações de dependência econômica ou simplesmente alteram as relações de concorrência seja entre as contratantes ou entre as contratantes e terceiros por meio da relação contratual. Deste modo, tais estruturas representam desafios complexos para o direito da concorrência, principalmente para identificar aquelas operações que estariam sujeitas ao controle preventivo ou de estruturas.

\footnotetext{
${ }^{32}$ Segundo o Conselheiro, a transferência de tecnologia e patentes entre concorrentes poderia resultar em riscos consideráveis para o ambiente concorrencial, uma vez que setores de alta tecnologia envolvem grande assimetria de informações sobre as estruturas de mercado e por esta razão seria mais prudente que a autoridade antitruste conhecesse das operações. Enfatizou, neste sentido, que os riscos concorrenciais só poderiam ser afastados após uma análise do conteúdo formal e material do acordo e seu contexto, o que seria feito caso a caso.
} 


\subsection{UMA NOVA REALIDADE PARA O SISTEMA DE CONTROLE PREVENTIVO}

O cenário econômico mundial passou por várias e profundas mudanças estruturais que criaram uma série de questões concorrenciais até então inexistentes. Muitas dessas alterações estão associadas ao fenômeno da globalização de mercados e da internacionalização da economia (Frazão 2015). Como nota Baker (2002, p.68), a evolução natural da economia de mercado leva à criação de formas de organização empresariais inovadoras que levantam novos e inesperados desafios à defesa da concorrência.

Como visto anteriormente, as alterações no substrato econômico evidenciam novas formas de estruturação da organização econômica, que desafiam a clássica dicotomia coasiana entre empresa e mercado (Frazão 2015). Consequentemente, destaca-se, nesse processo, o surgimento de soluções contratuais que procuram estabelecer estruturas de governança das relações interempresariais que buscam alcançar, por um lado, uma base suficientemente estável para sustentar os compromissos empresarias, mas, por outro lado, preservar a flexibilidade da relação a fim de possibilitar a adaptação a futuras contingências. Trata-se, desta forma, da constituição de uma "terceira-via" entre a empresa e o mercado.

Todavia, o universo de alternativas que podem ser consideradas uma "terceira via" é extremamente vasto, o que representa um novo desafio para o direito da concorrência, na medida em que exige, no mínimo, reflexões sobre a delimitação do objeto do controle, especialmente o controle preventivo antitruste. Isso porque essa modalidade de controle pode afetar sobremaneira não somente as partes relacionadas, como também o desenvolvimento industrial e o próprio desempenho da autoridade nas suas funções.

De fato, a política concorrencial a ser direcionada a esses tipos de contrato requer uma reflexão sobre as particularidades de cada tipo de acordo. Isso não impede, contudo, que algumas características gerais sejam apreensíveis a partir dos contratos cooperativos como um todo.

Por sua natureza, por se tratar de acordos com prazo relativamente longos entre as partes, os acordos cooperativos geralmente resultam na exclusão de outras firmas ou simplesmente criam dificuldades para que elas igualmente estabeleçam relações comerciais com as empresa integrantes do acordo (Mariti e Smiley 1999, p. 288).

Nesse quadro de relações, as empresas também buscam por meio do acordo impedir que a relação venha a prejudicar sua própria posição no mercado, ou simplesmente que a ruptura de tais contratos venha a prejudicar sua atividade no futuro. Consequentemente, 
as empresas procuram reduzir esse risco por meio de cláusulas restritivas e uma estrutura de planejamento previamente acordada cuidadosamente (Mariti e Smiley 1999, p. 288).

Os acordos horizontais, por exemplo, podem resultar no aumento da concentração do mercado - redução do número de players concorrentes - se ambas as firmas resolvem cessar a produção daqueles produtos produzidos de forma independente entre elas. Igualmente, colusão e cartelização podem ser facilitadas por meio da troca de informações em decorrência de acordos de cooperação horizontal. Mesmo raciocínio se aplicaria aos acordos verticais que podem eliminar rivais em cada estágio do processo produtivo, ou simplesmente aumentar o custo do rival de forma ilegítima, ou reduzir a concorrência potencial entre as empresas na hipótese de serem também horizontalmente relacionadas. Dentre outros efeitos anticompetitivos, destaca-se o fechamento de mercado, seja pela restrição do acesso a insumos (input foreclosure) ou pela restrição do acesso ao mercado consumidor (consumer foreclosure).

Por outro lado, como visto ao longo desse capítulo, os acordos cooperativos resultam em eficiências econômicas e, em alguns casos, até mesmo reforçam o processo competitivo no mercado propiciando economias de custo, a melhorias de pesquisa e maior possibilidade de financiamento das atividades. Deste modo, os efeitos dos acordos de cooperação sobre a concorrência são mistos e controversos (Mariti e Smiley 1999, p. 289).

A técnica legislativa empregada no novo ordenamento concorrencial brasileiro procurou submeter, por disposições do artigo 90, os acordos de cooperação ao controle preventivo. Tal previsão, contudo, ainda é marcada por uma relativa vagueza terminológica.

A indefinição conceitual se justifica justamente por uma necessidade constante de revisão terminológica para dar conta de uma nova realidade empresarial (Gormsen 2010, 11). Trata-se de uma solução legislativa conscientemente evolutiva (Kovacic e Shapiro 1999, p. 19), que permite um desenvolvimento progressivo do direito antitruste à luz da experiência (Mendes 2013, p. 36).

Esse tratamento se justifica em razão de o poder econômico não estar enraizado só em estruturas econômicas existentes, mas também em relações econômicas, as quais são definidas e organizadas com base no exercício de poder (Salomão Filho 2013, p. 73). Sendo assim, uma vez que o controle preventivo se volta a prevenir a formação e concentração do poder econômico é de se esperar que as formas de cooperação que levam a esse resultado sejam submetidas ao controle. 
Ocorre que tais estruturas de poder, principalmente nas relações contratuais, não são facilmente detectáveis. É possível notar ainda muita controvérsia a respeito dos requisitos para a configuração do ato de concentração que envolva outras formas de controle que se afastam dos moldes societários tradicionais. Identificar as fontes de poder econômico nestas circunstâncias requer a aplicação de diferentes esquemas conceituais para a sua compreensão e de diferentes métodos para a sua regulação, procurando desenvolver uma abordagem estrutural das relações econômicas levando em consideração os elementos dinâmicos e, sobretudo, o fator incerteza ligado ao processo competitivo (Korah, 2000).

Sendo assim, quando a relação é baseada em contrato e não é acompanhada de disposições claras sobre a existência de um novo centro de poder, conservadorademente não pode estar sujeito ao controle preventivo, por não se tratar rigorosamente de uma concentração empresarial, cabendo portanto, nestes casos, apenas o controle a posteriori caso algum potencial anticompetitivo fosse identificado (Salomão Filho 2013, p. 135).

Independentemente dessa discussão, uma coisa é certa, os acordos de cooperação tem capacidade de alterar a estrutura competitiva do mercado (Mariti e Smiley 1999, p. 289), e, portanto, são objetos de preocupação do direito concorrencial. Daí as conclusões de Ana Frazão no sentido de que tais modalidades lançam "novos desafios ao controle de estruturas, especialmente no que diz respeito à delicada e complexa tarefa de encontrar critérios para se entender a organização da empresa e, consequentemente, as diferentes e múltiplas formas de concentração empresarial" (Frazão 2015a, p. 10).

Diante desse quadro, as novas modalidades de organização da atividade empresarial levantam uma questão de suma importância para a adequada implementação da política de defesa da concorrência, que é justamente a necessidade do seu enquadramento no conceito de ato de concentração para fins de submissão à análise do CADE em sede de controle de estruturas. Há, portanto, uma necessidade de se fazer reflexões sobre a delimitação do objeto de incidência do controle preventivo previsto nos artigos 88 e 90 da Lei n. 12.529/2011, procurando estabelecer em que medida os acordos de cooperação se enquadram nas hipóteses de notificação de atos de concentração.

Em se tratando dos meros contratos de cooperação ${ }^{33}$, as contratantes mantêm a sua independência econômica e financeira, não reestruturam internamente a sua gestão ou poder

\footnotetext{
${ }^{33}$ Neste ponto é importante destacar mais uma vez que os contratos associativos não são meros contratos cooperativos, uma vez que são qualificados pela existência de um fim em comum entre as contratantes, o que será mais bem explorado no capítlo seguinte.
} 
de controle e não necessariamente adquirem ativos e, se o fazem, isso se dá de forma meramente instrumental.

Embora, com relação a estes contratos, a questão em torno do enquadramento no conceito de ato de concentração tenha se dado ainda no âmbito da Lei n. 8.884/1994, a praxis decisória do CADE permite uma reflexão sobre o tratamento que esses contratos podem receber do novo diploma. Essa reflexão pode contribuir para um melhor delineamento, ainda que preliminar, da interpretação do CADE com relação aos novos dispositivos trazidos pela Lei n. $12.529 / 2011 .^{34}$

As operações envolvendo contratos de execução continuada (e.g., contratos de distribuição, fornecimento e licenciamento de tecnologia) foram, no passado, de maneira geral, conhecidas pelo CADE tendo em vista os critérios objetivos de participação e/ou faturamento estabelecidos no parágrafo $3^{\circ}$, do artigo 54 da Lei n. 8.884/94.

Posteriormente, em 2006, quando do julgamento do Ato de Concentração 08012.011058/2005-74 ${ }^{35}$, inaugurou-se o debate com relação a necessidade de conhecimento dos referidos contratos. Neste caso, o Conselheiro Paulo Furquim proferiu votou pelo não conhecimento da operação, que se trantava de um contrato de fornecimento de clínquer entre a Holcim e a Camargo Correa, em razão da ausência de cláusula de exclusividade no contrato. Não obstante, o Plenário, por maioria, decidiu pelo conhecimento.

A questão foi novamente discutida em razão da análise da Consulta $n^{\circ}$ 08700.003674/2007-65 realizada pela Fujifilme da Amazônia Ltda. sobre a necessecidade de notificação de contrato de fornecimento não exclusivo de materiais fotográficos a ser futuramente celebrado entre a consulente e a Noritsu do Brasil Ltda. Mais uma vez, houve divergência no Conselho, opinando a maioria pelo conhecimento do contrato de fornecimento ainda que não constasse cláusula de exclusividade.

Ainda no ano de 2008, o Conselho não conheceu por unanimidade o Ato de Concentração $n^{\circ}$ 08012.010018/2008-58, em que o Relator Olavo Chinaglia entendeu que o contrato de fornecimento de glifosato celebrado entre a Monsanto do Brasil Ltda. e a Nufarm Indústria Química e Farmacêutica S.A não era capaz de provocar qualquer dano ao ambiente competitivo, uma vez que não havia transferência, compartilhamento ou cessão de ativos tangíveis ou intangíveis e que, pela incompatibilidade do negócio com o conceito de

\footnotetext{
${ }^{34}$ Voto-Vogal proferido pelo Presidente do CADE, Vinícius de Carvalho, no julgamento dos Atos de Concentração Monsanto em 2013.

${ }^{35} \mathrm{AC} \mathrm{n}^{\mathrm{o}}$ 08012.01158/2005-74. Requerentes: Holcim S.A. e Camargo Correa Cimentos S/A. Relator: Paulo Furquim de Azevedo. Julgado em: 26.07.2006.
} 
concentração econômica, tratando apenas de mero contrato comercial regular entre dois agentes econômicos, a operação não estaria compreendida nos atos do artigo 54 , parágrafo $3^{\circ}$ da Lei n. 8.884/94.

Após este período de reflexão quanto a obrigatoriedade de notificação, vários outros $^{36}$ contratos de fornecimento foram apresentados ao CADE, sem cláusula de exclusividade, sendo todos conhecidos e aprovados sem restrições, até que, em março de 2010, a questão do conhecimento volta a ser novamente discutida pelo Conselho no julgamento do AC 08012.000182/2010-71.

Neste caso, a Declaração de Voto do então Presidente Arthur Badin foi seguida pela maioria, vencido o Relator, em que constatou que

"a análise dos casos acima demonstra que contratos de fornecimento que (a)
não impliquem transferência de ativos concorrencialmente relevantes, (b)
não contenham cláusula de exclusividade ou equivalentes de qualquer
natureza capazes de restringir o direito de decisão sobre os ativos (produtos e
serviços), (c) tenham prazo de vigência inferior a cinco anos (consideradas
eventuais prorrogaçães), (d) contemplem a possibilidade de rescisão
imediata sem ônus à parte requerente, (e) não representem a negociação de
um volume de produtos superior ao percentual estabelecido no art. 54, $3^{\circ}$,
da lei n. 8.884/94, prescindem de notificação ao SBDC por não serem
capazes de limitar ou prejudicar a concorrência ou deles resultar a
dominação de bens ou serviços".

Desde então, o CADE parece ter replicado em suas decisões o entendimento no sentido de que a ausência de transferência de ativos de qualquer sorte, vínculos societários de qualquer natureza [ou] cláusula de exclusividade fazem com que um contrato não deva ser conhecido, mesmo que tenha sido celebrado entre concorrentes. ${ }^{37}$

O debate sobre o conhecimento de contratos de execução continuada ganhou novamente destaque no mais recente julgamento dos Atos de Concentração apresentado pela Monsanto, julgados em 2013 pelo CADE. Independentemente das nuances do caso, é possível notar que a decisão final do CADE seguia a tendência do Conselho nos últimos anos de questionar apenas a necessidade de submissão de contratos desse tipo na ausência de cláusulas capazes de restringir a concorrência, como eram os casos das cláusulas de exclusividade.

\footnotetext{
${ }^{36}$ AC 08012.004452/2009-08 entre Monsanto e Caraíba; AC 08012.006034/2009-27 entre Monsanto e IMA; AC 08012.006367/2009-56 entre Monsanto e Milenia; AC 08012.007963/2009-53 entre Monsanto e Basf; AC 08012.009905/2009-64 entre Syngenta e Irvita; AC 08012.008815/2008-75 entre Fujifilme e Noritsu (apresentado em razão da Consulta no 08700.003674/2007-65); AC 08012.004343/2009-62 entre Dow e Nortox; AC 08012.006858/2009-02 entre Votorantim e CSN.

${ }^{37}$ AC no 08700.009957/2013-69. Requerentes: Raízen Energia S.A. e Novozymes A/S. Aprovado sumariamente pela Superintendência-Geral em 13.12.2013.
} 
Em 2012, a Monsanto do Brasil Ltda. apresentou uma série de operações ${ }^{38}$ ao Conselho Administrativo de Defesa Econômica que consistiam em Contratos de Licenciamento Comercial, por meio do qual a Monsanto concederia licença não exclusiva para desenvolver, testar, produzir e comercializar variedades de sementes de soja Intacta RR2 $P R O^{T M}$ no Brasil pelas licenciadas, além de licenciar o uso da marca Intacta RR2 PRO detido pela Monsanto.

Quando levadas a julgamento, houve divergências entre os membros do Conselho com relação ao conhecimento e a necessidade de notificação das operações, uma vez que não havia qualquer cláusula de exclusividade entre elas.

O Conselheiro Marcos Paulo Veríssimo, em seu voto, apresentou uma análise sistemática do histórico de julgamentos de operações envolvendo contratos de licenciamento pelo CADE entre os anos de 2005 a 2012, e concluiu, em suma, que tais contratos não deveriam ser conhecido quando, por um análise prima facie, não fosse possível identificar (i) formação de empreendimentos em comum ou forma de atuação conjunta; (ii) troca ou rearranjo de participação societária entre as Requerentes ou entre estas e terceiras empresas e; (iii) cláusulas de exclusividade ou cláusulas contratuais que influenciem a atuação concorrencial independente de ambas as partes.

Já o Conselheiro Alessandro Octaviani, conservadoramente, entendeu pela necessidade de conhecimento de tais operações, ainda que ausente qualquer exclusividade entre elas. Segundo ele, o mercado de alta tecnologia envolve muita assimetria de informação, e, sendo assim, o CADE deve adotar uma postura cautelosa e conhecer de tais operações, para dizer caso a caso quais apresentam riscos ao ambiente concorrencial. O Conselheiro procurou demonstrar que diante das características desse mercado, "hipóteses de não-conhecimento em bloco podem ser verdadeiros "cheques em branco", demandando ônus argumentativo muito maior, fundado em estatísticas consolidadas e estáveis, sobre a trajetória tecnológica e seus padrões de formação de estruturas". No mesmo sentido, destacou que a transferência de tecnologia poderia resultar na formação de um modelo de dominação empresarial $a b$ extra, em que as estruturas poderiam ser formadas pela simples dependência da própria tecnologia (com compras, licenças com ou sem exclusividade), do crédito, do acesso às redes de distribuição, tudo isso amparado nos fatos, muito mais do que nos textos contratuais.

\footnotetext{
${ }^{38}$ Vide nota n. 31
} 
A Conselheira Ana Frazão, por sua vez, entendeu pelo não conhecimento das operações uma vez que, do ponto de vista legal, contratos de licenciamento de patente sem exclusividade não teriam o potencial de produzir "concentração econômica" (na verdade, geraria "desconcentração"), não se enquadrando propriamente no conceito de ato de concentração para fins de aplicação da Lei n. 12.529/2011.

Para a Conselheira, os contratos seriam meramente comutativos de longa duração, já que uma das partes cede à outra o direito de usar a sua propriedade intelectual mediante remuneração. Não se cogitaria nem de comunhão de fim, nem de prestações idênticas ou semelhantes, nem mesmo da existência de uma organização comum entre licenciante e licenciadas.

Ademais, entendeu que mesmo que se adotasse uma perspectiva mais ampla do conceito de contratos associativos, os contratos de licenciamento sem exclusividade não poderiam ser enquadrados nessa modalidade para fins de aplicação da Lei, já que o mero objetivo de cooperação ou colaboração não seria suficiente para atrair o controle preventivo, visto que todo contrato, de certa forma, se preza a isso.

As preocupações manifestadas pela Conselheira foram no sentido de que definições latíssimas de contratos associativos, com substrato no conceito amplo de cooperação, implicaria tornar associativos vários - senão todos - contratos empresariais de execução continuada no tempo, tais como mandato, agência, distribuição, comissão mercantil, concessão mercantil, representação e franquia, os quais podem apresentar muito mais elementos "associativos" do que o contrato de licenciamento de patente.

Assim, a Conselheira entendeu que tais contratos exerciam suas funções típicas, mantendo a comutatividade que lhes é inerente, sem nenhuma cláusula que o desnaturasse para um contrato associativo ou para um ato de concentração.

O Conselheiro Elvino Mendonça, em seu voto, destacou que somente na hipótese de tais contratos possibilitarem o fechamento de mercado ou resultarem barreiras à entrada, traduzidas nas cláusulas de não concorrência e/ ou cláusulas de exclusividade, é que tais contratos seriam de conhecimento obrigatório.

O caso, no entanto, foi, ao final, conhecido pelo Conselho e, no mérito, aprovado sob condições de adequação de algumas cláusulas contratuais. Naquela ocasião, o Conselheiro Eduardo Pontual verificou que não se tratava de um simples contrato de licença de patentes 
em razão da presença de cláusulas contratuais específicas que revelavam certa integração entre as contratantes. Nos termos do voto,

o conhecimento ou não de contratos de transferência de tecnologia via contratos de licenciamento em cultivares depende da existência de características contratuais que envolvam exclusividade no uso da capacidade produtiva da empresa licenciada, ou envolvam restrições ou desincentivos na escolha da contratação de outros licenciadores por parte da licenciada, ou envolvam restrições ao desenvolvimento de produtos concorrentes próximos do bem desenvolvido a partir do insumo ou evento licenciado.

Analisando os contratos apresentados, o Conselheiro identificou disposições que previam o pagamento de um prêmio adicional proporcional ao percentual da capacidade de produção da licenciada destinado a produção de sementes com tecnologia Monsanto. Deste modo, a cláusula contratual criava um incentivo para que as licenciadas desenvolvessem e comercializassem mais sementes com a tecnologia da Monsanto. Observou o Conselheiro que, naquele caso,

Uma empresa que detiver a patente de um produto concorrente da soja Intacta terá de pagar um prêmio para os obtentores já comprometidos em suas variedades com a Monsanto, pois quando da multiplicação cada unidade não Monsanto produzida traz o potencial de um duplo prejuízo: a perda do incentivo daquela unidade (perda esta usual, por escolha individual da licenciada) e a redução na remuneração de toda a produção licenciada de Intacta, se mudar o patamar no mix de portfólio. O contrato é tal que a Monsanto regula financeiramente a remuneração de marcas adquiridas de outros de obtentores, através de atos de concentração, se aquisição envolver empresas já licenciadas para "Intacta RR2 PRO” ou não)

Importante observar que as disposições contratuais não eram propriamente obrigatórias, pois a licenciada poderia decidir não multiplicar ou comercializar seu cultivar livremente com outras empresas. Não obstante, a licenciada teria menor interesse em investir em pesquisa e desenvolvimento de produto concorrente da Monsanto, porque no momento da produção e comercialização do seu produto, em caso de sucesso na pesquisa, ela perderia parte da receita investida na Monsanto. Sendo assim, os contratos firmados com algumas das licenciadas continham um sistema de incentivos que possibilitavam certa influência da Monsanto nas decisões comerciais da licenciada além dos produtos sujeitos à licença.

Nesta linha, o Conselheiro verificou que os contratos analisados traziam cláusulas que apontavam os esforços para um bem comum entre licenciante e licenciada, por meio do financiamento do desenvolvimento de produtos de forma conjunta (com a venda do cultivar) e com uma influencia concorrencial clara nos negócios outros da licenciada que não com a 
Monsanto. Igualmente concluiu que, embora não seja um sistema de exclusividade propiramente dito, possui o condão de elevar as barreiras à entrada sem justificativa econômica, exceto a busca pelo aumento dos lucros por parte da Monsanto.

De modo geral, o Conselho Eduardo Pontual entendeu que os contratos de licenciamento de tecnologia deveriam ser notificados quando (i) estabelecessem algum tipo de exclusividade ou pudesse ter efeitos similares na capacidade produtiva do adquirente; (ii) incluíssem cláusulas restritivas ou desincentivos para adquirir licenças concorrentes; (iii) introduzissem restrições no desenvolvimento de produtos concorrentes; ou (iv) resultassem qualquer tipo de influência nas decisões comerciais da adquirente.

É possível notar que, em regra, tais contratos correspondem tão somente a um esquema organizado de trocas ou a uma operação complexa de troca baseados no mecanismo do preço (Pinheiro 2003, 167). Não obstante, referidos contratos podem vir acompanhados de elementos necessários para garantir maior estabilidade nas relações e conter cláusulas que extrapolem seu objeto e sua função econômica (enquanto meramente comutativos), permitindo certa influência ou controle de uma das partes sobre a atividade empresarial da outra, o que acaba ocasionando possíveis restrições nas relações de concorrência do mercado $^{39}$. Nestes casos, estar-se-á diante de um arranjo contratual próprio que possibilita a ampliação ou consolidação do poder empresarial de um contratante sobre o outro.

Nesse contexto, no que se refere aos contratos de longa duração, a autoridade antitruste deve ser sensível a cláusulas contratuais que, extrapolando o objeto usual de um contrato de licença de patentes, possibilitam uma cooperação diferenciada entre as contratantes, que, analisadas sob uma perspectiva macro, tem levado a efeitos semelhantes das hipóteses clássicas de concentração econômica no que diz respeito à agregação de poder empresarial das contratantes (ou de uma delas) e, consequentemente, ao aumento de poder de comando ou gestão empresarial. ${ }^{40}$ Por tal razão, a Conselheira Ana Frazão alterou seu julgamento para, ao final, conhecer das operações da Monsanto, acompanhando o Conselheiro Eduardo Pontual quanto às restrições aplicadas ao caso.

\footnotetext{
$39 \mathrm{AC} \mathrm{n}^{\mathrm{o}}$ 08012.006150/1999-11; 08012.004600/2005-32; 08012.006362/2005-08; 08012.000491/2005-84; 08012.006415/2005-82; $\quad 08012.003427 / 2003-93 ; \quad 08012.007073 / 2003-56 ; \quad$ 08012.007081/2003-01; 08012.005042/2004-41; 08012.009279/2004-00; 08012.004661/2006-81.

${ }^{40}$ Neste sentido foi o Voto-Vogal da Conselheira Ana Frazão no julgamento dos Atos de Concentração da Monsanto em 2013.
} 
Essa reflexão pode contribuir para um melhor delineamento, ainda que preliminar, da interpretação do CADE com relação aos novos dispositivos trazidos pela Lei n. 12.529/2011. A jurisprudência do CADE, ainda que não seja consolidada a respeito das hipóteses de notificação dos contratos associativos, apresenta indicativo a respeito de alguns aspectos que podem ser utilizados na definição de filtros adequados na estruturação da política de defesa da concorrência no país com relação a estes contratos.

Deste modo, foi acertada a decisão do Conselho em conhecer as operações da Monsanto, pois os contratos apresentavam cláusulas que, ainda que não fossem explícitas no sentido da existência de um contrato associativo, eram indicativos muito próximos nesse sentido.

Como bem salientado pelo Presidente do CADE, Vinícius de Carvalho, em seu voto-vogal no caso Monsanto, ainda que a Lei n. 12.529/2011 tenha afastado o potencial anticompetitivo das operações como critério de definição de ato de concentração, isso não significa que este potencial seja completamente indiferente para o novo regime. Na verdade, o que muda é o papel que tais considerações assumem atualmente como fundamento lógico dos critérios objetivos a serem ditados pelo CADE na identificação dos casos previstos no artigo 90, sendo utilizados como parâmetros a partir dos quais seja possível presumir a existência de uma concentração empresarial.

Não obstante, é preciso ter em mente que a definição de critérios objetivos deve, principalmente, resguardar o conteúdo próprio dos contratos associativos, de modo que a sua autonomia conceitual não se perca a partir de critérios demasiadamente amplos que, igualmente, afastam a vontade do legislador a respeito dos requisitos estabelecidos na nova Lei. Torna-se necessário, portanto, a compreensão conceitual do que venha a ser um contrato associativo e o seu devido enquadramento nas hipóteses de notificação dos atos de concentração. 


\section{CONTRATOS ASSOCIATIVOS}

No primeiro capítulo verificou-se que a Lei n. 12.529/2011, que revogou a Lei n. 8.884/94, trouxe novos parâmetros de delimitação do objeto de incidência do controle preventivo do CADE, a partir de critérios mais rígidos de notificação: (i) faturamento mínimo legal e (ii) ocorrência de um ato de concentração. Nesta linha, o conceito de ato de concentração assume relevância na aplicação do dispositivo legal.

Por outro lado, foi possível observar que definir critérios de notificação é tão importante quanto buscar uma conceituação de "ato de concentração", porque, na prática, a implementação do que seria um "ato de concentração" se mostra mais complexa do que no plano teórico. Essa preocupação se mostra relevante diante dos novos desafios do antitruste, hoje representados pelos acordos de cooperação que, apesar de não se enquadrarem propriamente no conceito de ato de concentração, têm levado a efeitos semelhantes no mercado.

Acordos de cooperação podem assumir distintas formas legais ${ }^{41}$, sendo três delas de especial relevância para aplicação da Lei n. 12.529/2011: os consórcios, as joint ventures e os contratos associativos. Deste modo, cabe à autoridade antitruste identificar critérios claros e objetivos a partir dos quais é possível, a partir destas modalidades de cooperação, presumir a existência de uma concentração econômica, aqui compreendida como forma de crescimento externo do poder empresarial, que envolve a união de esforços ou recursos de agentes econômicos distintos que, de alguma maneira, tornar-se-ão uma unidade para efeitos econômicos.

A primeira dificuldade relacionada ao assunto diz respeito à ausência de delimitação material do que se deve considerar como contrato associativo para fins de aplicação do dispositivo legal, já que definições amplas deste conceito podem abarcar qualquer transação comercial realizada entre empresas no curso normal dos negócios.

Apesar das dificuldades inerentes ao assunto, o ponto de partida da análise é tentar compreender os contratos associativos, enquanto estruturas que correspondem a "terceiravia”, a partir de suas diferenças com as formas extremas de organização da atividade empresarial. Ademais, identificar aspectos semelhantes e distintos com relação às demais

\footnotetext{
${ }^{41}$ Em sua obra Mariti e Smiley citam como exemplos de contratos cooperativos os consórcios licitantes e joint ventures. (1999, p. 279).
} 
formas de cooperação expressas na Lei também pode ajudar a compreender o núcleo próprio dos contratos associativos, o que se procura fazer a seguir.

\subsection{FORMAS DE “CONCENTRAÇÃO POR COOPERAÇÃo”}

Acordos de cooperação podem assumir distintas formas legais ${ }^{42}$, mas três delas são de especial relevância para aplicação da Lei n. 12.529/2011: os consórcios, as joint ventures e os contratos associativos. Independentemente da forma que venham assumir, uma coisa é certa, os acordos de cooperação têm capacidade de alterar a estrutura competitiva do mercado (Mariti e Smiley 1999, p. 289), tornando-o, em alguns casos, mais concentrados. Tais acordos são, portanto, objeto de preocupação do direito concorrencial, inclusive pelas disposições do inciso IV, artigo 90 da Lei n.12.529/2011, que prevê formas de cooperação que podem estar sujeitas ao controle prévio.

Como bem observa Ana Frazão (2015, p. 14), o que todos esses arranjos têm em comum é desafiarem a dicotomia empresa/mercado proposta por Ronald Coase, apresentandose como estruturas que combinam elementos e características tanto da organização típica das empresas como também da coordenação inerente ao mercado. Isso significa que tais arranjos podem apresentar em sua composição tanto elementos estruturais quanto elementos comportamentais, inclusive em decorrência de uma relação obrigacional, apresentando-se como formas híbridas entre a concorrência de mercado (onde predomina o comportamento) e a hierarquia da firma (onde predominam as estruturas). Sob essa perspectiva, a natureza concorrencial da relação existente entre as partes pode assumir formas tanto concentrativas (quando se dá pela formação de um novo centro de decisão), quanto cooperativas, muitas vezes não havendo uma distinção clara dessa natureza no caso concreto ${ }^{43}$.

Tais estruturas são propriamente técnicas de coordenação interempresarial que podem se dar, segundo Richardson, tanto por mecanismos de direção quanto por mecanismos de cooperação ${ }^{44}$ (Richardson 1999, p. 66). O primeiro, coordenação por direção, é empregado

\footnotetext{
${ }^{42}$ Em sua obra Mariti e Smiley citam como exemplos de contratos cooperativos os consórcios licitantes e joint ventures. (1999, p. 279).

43 Williamson (1999, p. 169) enfatiza que o paradigma das relações contratuais entre as empresas, tradicionalmente amparado na premissa de que essas relações são "sharp in by clear agreement; sharp out by clear performance", apresenta falhas uma vez que muitas relações contratuais não se assentam em tipos bem definidos.

44 Richardson (1999, p. 66) ainda entende uma terceira forma de se dar a coordenação interempresarial. "Coordination may come about spontaneously through market transection, without benefit of either direction or co-operation or indeed any purposeful intent, as an indirect consequence of successive interacting decisions
} 
quando as atividades das partes relacionadas estão sujeitas a um controle único, e, assim, estão orientadas para a consecução de um único plano empresarial. Nestes casos, as atividades são consolidadas e realizadas conjuntamente por uma organização em comum ${ }^{45}$.

Já o segundo, a coordenação por cooperação, se dá quando duas ou mais firmas independentes concordam em estabelecer uma conexão entre seus respectivos planos empresariais com antecedência, para a consecução de um objetivo comum, não se utilizando, propriamente de um mecanismo de direção. É possível que o mecanismo de cooperação se aproxime da modalidade de direção na medida em que uma das partes é claramente predominante sobre a outra e algum grau de harmonização ex ante dos planos seja estabelecido entre as partes em seus respectivos mercados de atuação (Richardson 1999, p. 66).

São justamente estas modalidades de relações empresariais que despertam preocupações às autoridades concorrenciais, na medida em que tais arranjos previstos no inciso III do art. 90 da nova lei são todos, em sua essência, uma "cooperação" de empresas que mantêm a sua autonomia em relação à outra, mas que, no entanto, estabelecem certa interdependência econômica em razão do objetivo em comum perseguido por ambas as contratantes.

"Cooperação" pressupõe que os entes participantes conservem a sua individualidade jurídico-econômica e que mantenham certa autonomia econômica e organizativa entre elas. Deste modo, na medida em que partes independentes se relacionam, "cooperação", entendida em seu sentido mais amplo, é qualquer acordo explícito de longa duração entre duas ou mais empresas autônomas, que pode ou não envolver alguma remuneração financeira (Mariti e Smiley 1999, p. 276). Um acordo de cooperação pode ser definido, nesta linha, como qualquer relação interempresarial que se localiza entre as formas extremas de contratos de curto prazo e a completa concentração empresarial entre duas ou mais empresas. ${ }^{46}$.

taken in response to changing profit opportunities". Essa coordenação, contudo, que não se dá de forma consciente e combinada entre as partes, não é objeto de incidência do direito da concorrência.

${ }^{45}$ Essa característica é evidente nas joint ventures. Como se verá no próximo capítulo, a formação de uma joint venture resulta necessariamente na formação de um novo centro de direção/decisão, diferentemente daquele que havia previamente à operação.

${ }^{46}$ Nesta linha, cooperação envolve, de acordo com Contractor e Lorange (2002) several governance modalities ranging from relational contracting to licensing, to logistical supply-chain relationships, to equity joint ventures. (Contractor e Lorange 2002, p. 486). 
Isso significa que transações ocasionais de bens ou serviços não se enquadram como acordos de cooperação, mas se apresentam tão somente como atos isolados de comércio. O fator tempo é, portanto, determinante para a caracterização do acordo de cooperação.

Outro aspecto apontado por Mariti e Smiley é a necessidade de haver uma clara disposição das partes no sentido da cooperação ${ }^{47}$. Ainda nesta linha, importante destacar que, enquanto as partes relacionadas não assumem qualquer obrigação a respeito das suas futuras condutas, não haverá qualquer processo de cooperação entre elas. Na ausência de qualquer continuidade da associação para além daquela atividade específica contratada, haverá tão somente um ato isolado de comércio. Deste modo, acordos de cooperação requerem para sua configuração o estabelecimento de ligações interorganizacionais estáveis e duradouras entre as partes, direcionada a uma regulação do futuro da relação entre elas (Mariti e Smiley 1999, p. 289).

Ocorre que, para um acordo de cooperação ser objeto de incidência do controle preventivo do antitruste, nos moldes determinados pelos artigos 88 e 90 da Lei n. 12.529/2011, deve haver, necessariamente, uma "cooperação qualificada" entre as partes, que implique elementos concentrativos de mercado, dando ensejo a modalidades de "concentração por cooperação". Neste sentido é a lição de Salomão Filho (2013) de que é preciso identificar o caráter concentrativo dessas relações para poder aplicar-lhes a disciplina do controle preventivo, por força da limitação do art. 88 da Lei. Nesta linha, não é qualquer cooperação que está submetida ao controle preventivo, mas tão somente aquelas qualificadas pela existência de um escopo em comum entre os contratantes.

Luis Lima Pinheiro (2003, p. 40) trouxe um conceito elaborado para acordos de cooperação qualificada e destacou, como elemento essencial dessa modalidade, a realização de um "empreendimento comum" entre as empresas relacionadas, que pode consistir em um ato concreto ou em uma atividade abstratamente definida a ser exercida com certa permanência susceptível de gerar um resultado econômico que, em princípio, a todos beneficia. Isso significa que a cooperação qualificada pelo escopo em comum dá ensejo a

\footnotetext{
${ }^{47}$ Nas palavras dos autores, só porque a maioria do insumo é adquirido ex post [a existência um contrato] de um único fornecedor, não implica que há um acordo de cooperação em vigor entre eles, a menos que tenha havido uma compreensão explícita de ambas as partes nesse sentido antes mesmo da ocorrência do fato (Mariti e Smiley 1999). Deste modo, não haveria que se falar em cooperação de fato. Deve haver uma clara disposição das partes no sentido da cooperação. Caso contrário, estar-se-ia diante de uma coordenação de mercado.
} 
formação de uma nova "empresa", compreendida aqui na sua acepção mais ampla como uma unidade econômica.

Concentração qualificada significa, portanto: (i) uma obrigação estabelecida de comum acordo entre as partes; (ii) para realizar uma atividade em comum ou de forma concertada; (iii) com vista à realização de um objetivo econômico em comum; (iv) sem perda da autonomia jurídica das empresas participantes. Isso significa que, de modo geral, as concentrações por cooperação abarcam qualquer "ação realizada em proveito mútuo" (Lima Pinheiro 2003, p. 57), desde a constituição de contratos associativos - que são desprovidos de uma organização comum mais rígida - até as hipóteses de fusão e aquisição de empresas que são formas de concentração pura.

Os acordos de cooperação qualificada podem representar estratégias de organização da atividade empresarial que não dependem propriamente da estruturação de vínculos societários. As empresas contratantes, embora mantenham sua autonomia jurídica, podem unir-se para alcançar um fim comum, sem que isso resulte na formação de uma nova pessoa jurídica. Deste modo, diferentemente das usuais formas de concentração empresarial, a concentração por cooperação pode resultar tão somente na formação de um empreendimento comum, na medida em que, por uma mera relação obrigacional, as partes podem estabelecer um objetivo em comum e coordenar suas atividades para esse fim, seja em conjunto, seja de forma complementar, dando ensejo a uma nova unidade econômica, não necessariamente estruturada em torno de uma organização institucionalizada.

Isso significa que algumas modalidades de cooperações qualificadas pelo escopo comum, ainda que não resultem necessariamente na formação de uma nova instituição empresária, são capazes de ocasionar uma concentração no mercado mais acentuada do que aquela pré-existente à operação. Isso porque dessa cooperação qualificada é possível observar fenômenos de concentração empresarial, na medida em que a fixação de um fim em comum resulta na perda subjacente da autonomia econômica das partes relacionadas, que se diluirá na formação de uma nova estrutura de mercado e na alteração das relações de concorrência no segmento em que pretendem atuar, dando, portanto, ensejo a uma nova unidade econômica.

As concentrações por cooperação são, por conseguinte, concentrações parciais, na medida em que os entes empresariais que exploram o empreendimento comum mantêm sua individualidade jurídica, (Lima Pinheiro 2003, p. 253), no entanto, com relativa perda de autonomia econômica em razão do escopo em comum estabelecido entre elas. Isso porque se 
o feixe de relações contratuais tivesse aptidão para abarcar o conjunto total das atividades desenvolvidas pelas participantes, em princípio, ultrapassaria a fronteira da categoria de cooperação, criando verdadeiros processos de concentração empresarial (Silva Morais 2006, p. 226). Essa circunstância não parece ser, todavia, o objeto de incidência da legislação quando estabeleceu a necessidade de controle preventivo das formas de cooperação.

É justamente nessa hipótese que seriam configuradas, portanto, as modalidades de concentração por cooperação. Tais modalidades não exigem, necessariamente, a formação de uma nova organização empresarial autônoma, sendo suficiente para a sua configuração a perda relativa de autonomia econômica das partes relacionadas em razão de um objetivo em comum traçado entre elas, já que essa perda de autonomia em função de um fim comum resulta na formação de uma nova unidade econômica capaz de alterar a estrutura de concorrência do mercado.

A título exemplificativo, a figura abaixo procura localizar as modalidades de concentração por cooperação que podem existir entre as formas extremas - empresa e mercado, onde predominam, respectivamente, as formas de concentração e coordenação - de relação entre empresas:

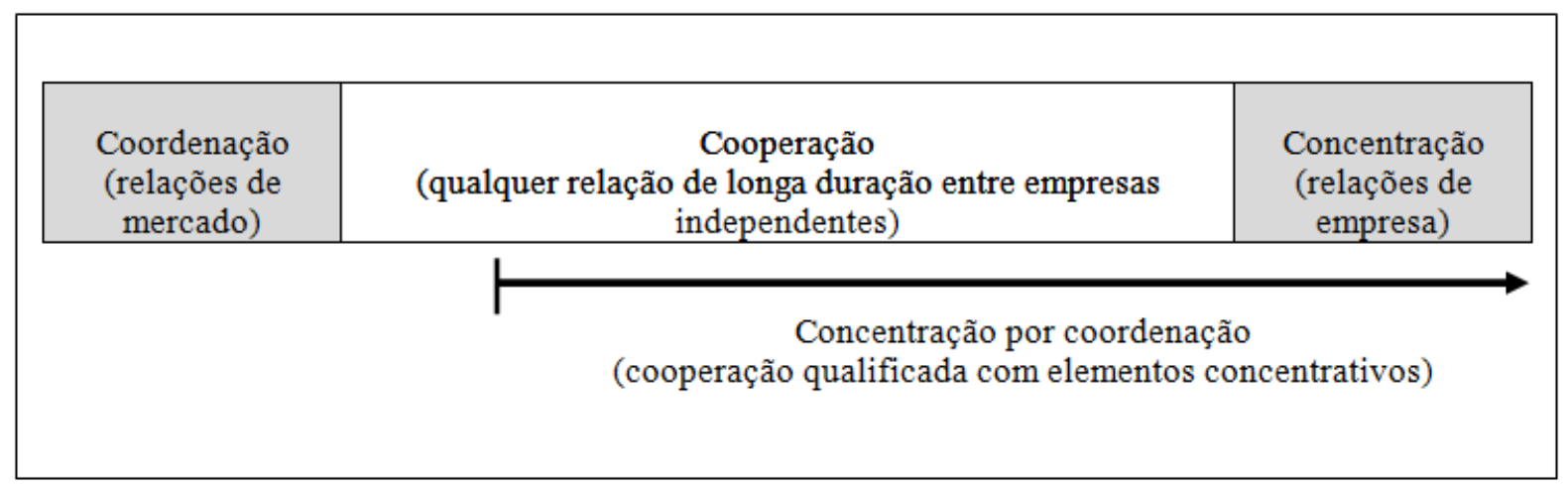

Fig.1 - Tipos de concentração por cooperação

* A figura procura retratar a cooperação empresarial compreendida em seu sentido mais amplo. Na linha do que os autores Mariti e Smilei (1999) entendem, cooperação como qualquer relação de longa duração entre as partes. Para autores como Williansom (1999), não basta que o contrato seja de longa duração, as cooperações empresariais envolvem elementos de governança projetados para disciplinar a atuação futura das partes.

Para os efeitos do presente estudo, entende-se o caráter concentrativo das cooperações quando dessas relações resulte na fixação de um fim comum entre as partes, resultando, consequentemente, na formação de uma nova unidade empresarial em razão da perda relativa de autonomia econômica subjacente a existência de um escopo em comum. Segundo Ana Frazão (2015a, p. 16), seria possível identificar o caráter concentrativo da operação a partir das seguintes hipóteses: (ii) o compartilhamento de risco entre os 
contratantes; (iii) a criação de uma interdependência organizativa que permita acompanhar, executar e monitorar a realização da atividade assumida pelas partes e (iv) a criação de um novo centro de controle da atividade empresarial.

Em suma, considera-se “concentração por cooperação", para fins de incidência do controle preventivo do antitruste, nos moldes do artigo 88 e 90, inciso III da Lei n. 12.529/2011, uma cooperação por meio da qual as partes estabeleçam (i) uma coordenação de comum acordo; (ii) para realizar uma atividade de forma conjunta ou complementar; (iii) com vista a realização de um objetivo econômico em comum; (iv) sem perda da autonomia jurídica das empresas participantes; sendo que, essa "cooperação qualificada" pode ser identificada por disposições contratuais que estabeleçam (ii) o compartilhamento de risco entre os contratantes; (iii) a criação de uma interdependência organizativa que permita acompanhar, executar e monitorar a realização da atividade assumida pelas partes e (iv) a criação de um novo centro de controle da atividade empresarial.

\subsection{ConsórCIOS}

Consórcios são exemplos típicos de cooperação empresarial, uma vez que, por determinação legal, são estruturados sem a perda da autonomia jurídica e financeira das pessoas jurídicas contratantes. Cada consorciado responde por suas obrigações, sem presunção de solidariedade entre as empresas participantes.

Trata-se de uma modalidade de cooperação limitada a um projeto específico, a partir do qual as empresas poderão extrair benefícios mútuos. A disciplina legal constante do artigo 278 da Lei das Sociedades Anônimas deixa clara a existência de um "empreendimento comum" entre os contratantes, que, no entanto, por se tratar de um contrato, dispensa a criação de nova pessoa jurídica. Os consórcios apresentam, nesta linha, uma cooperação qualificada pelo fim em comum, inclusive com estrutura organizativa própria e determinada legalmente, em que alguns autores os aproximam de verdadeiros contratos de sociedade (Frazão 2015). Isso porque muitas das cláusulas obrigatórias desse tipo contratual encontramse igualmente presentes nos contratos de sociedade (Frazão 2015). Conforme disposição do artigo 279 da Lei das AS, são cláusulas obrigatórios dos consórcios empresariais:

Art. 279. O consórcio será constituído mediante contrato aprovado pelo órgão da sociedade competente para autorizar a alienação de bens do ativo não circulante, do qual constarão: (Redação dada pela Lei ${ }^{\circ} 11.941$, de 2009)

I - a designação do consórcio se houver; 
II - o empreendimento que constitua o objeto do consórcio;

III - a duração, endereço e foro;

IV - a definição das obrigações e responsabilidade de cada sociedade consorciada, e das prestações específicas;

$\mathrm{V}$ - normas sobre recebimento de receitas e partilha de resultados;

VI - normas sobre administração do consórcio, contabilização, representação das sociedades consorciadas e taxa de administração, se houver;

VII - forma de deliberação sobre assuntos de interesse comum, com o número de votos que cabe a cada consorciado;

VIII - contribuição de cada consorciado para as despesas comuns, se houver. Parágrafo único. O contrato de consórcio e suas alterações serão arquivados no registro do comércio do lugar da sua sede, devendo a certidão do arquivamento ser publicada.

Como se verá a seguir, a figura do consórcio e as demais formas de cooperação prevista na Lei n. 12.529/2011 se intersectam em vários aspectos. Não obstante, adverte Luís Domingos Silva Morais (2006) que, uma vez que os consórcios são objeto de tipificação legal, não recebem, normalmente, um conteúdo jurídico-material unificado ou relativamente coerente, e utilizá-lo como paradigma para delinear os caracteres fundamentais dos contratos associativos, que não é objeto de tipificação legal no Brasil, pode gerar equívocos.

\subsection{JOINT VENTURES SOCIETÁRIAS E CONTRATUAIS}

O conceito nominal de joint venture surge no quadro do ordenamento norteamericano e a sua origem encontra-se associada ao desenvolvimento de modalidades jurídicas híbridas, que abrangem formas de cooperação e concentração empresarial.

As joint ventures, tal como os consórcios, são exemplos de estruturas intermediárias que constituem a "terceira via" entre a sociedade empresária e o mercado, na medida em que permitem sustentar um objetivo comum entre as empresas relacionadas, sem comprometer, por outro lado, a independência jurídica e econômica das partes relacionadas. A “terceira via" pode assumir uma multiplicidade variável de formas. Não obstante, é possível identificar traços comuns das joint ventures em razão da função jurídico-econômica que desempenham.

Primeiramente, é importante destacar que a joint venture se presta a uma modalidade concentração parcial de atividades, porque, caso contrário, se abrangesse todo o domínio de atuação das partes relacionadas, estar-se-ia diante de uma concentração empresarial e, não propriamente, de uma modalidade híbrida como é a joint venture, que conjuga em seu âmago elementos tanto de concentração como de cooperação empresarial. Segundo Luis Domingos Silva Morais (2006, p. 172), se determinado acordo abranger a 
generalidade das atividades das empresas relacionadas, deixando apenas de fora desse domínio atividades meramente residuais, ainda que as empresas o qualifiquem de joint ventures e mantenham sua individualidade jurídico-formal, estar-se-á diante de uma concentração empresarial pura, com aparência formal de joint venture. A peculiaridade da joint venture é possibilitar, assim, a implementação de um interesse comum por meio de parâmetros mais flexíveis do que aqueles previstos para as usuais formas de concentração empresarial (Frazão 2015).

Outro traço distintivo das joint ventures é a necessária existência de uma estrutura organizativa em comum entre as partes, a partir da qual seria executada a atividade empresarial (Frazão 2015). Essa estrutura pode apresentar contornos mais rígidos, por meio da criação de uma pessoa jurídica, ou mais imprecisos, como no caso das joint ventures contratuais.

Isso significa que, enquanto se traduz em uma modalidade de cooperação organizada, a joint venture pode ou não constituir-se a partir de uma organização dotada de personalidade jurídica. Enquanto nas joint ventures societárias (equity joint venture) a cooperação se organiza em torno de uma pessoa coletiva, as joint ventures contratuais (contractual joint ventures) não dão corpo a uma organização dotada de personalidade jurídica (Lima Pinheiro 2003, p. 77).

A formação de uma nova pessoa jurídica não é, portanto, elemento caracterizador da joint venture. Como explica Luis Lima Pinheiro (2003, p. 79), a criação de uma pessoa jurídica tem alcance limitado principalmente quando o objetivo do negócio é estabelecer uma relação de cooperação entre as partes relacionadas. Nas hipóteses, em que o caráter cooperativo se mostra mais relevante do que o integrativo, a eventual criação de uma pessoa jurídica em muitos casos tem aspecto instrumental, secundário ou até mesmo marginal da relação.

Independentemente da forma que a joint venture assumir, uma coisa, no entanto, é certa: a joint venture sempre resulta na formação de um novo ente empresarial (Mariti e Smiley 1999, p. 282). Tal característica, inclusive, justificou a definição de joint ventures pela doutrina portuguesa como a realização de uma "empresa comum", compreendida tanto sob a concepção de atividade ou de instituição (Silva Morais 2006). Isso significa que a "empresa comum", sob a concepção institucionalista, se traduz na ideia de obra ou empreendimento, isto é, uma programação que congrega atributos funcionais de diversos tipos, organizados de 
modo estável e autônomo, que disponha de uma estrutura organizativa. Ou ainda, sob a concepção de atividade, a "empresa comum" corresponde à conjunção de atos de comércio orientados para a consecução de determinada finalidade econômica (Silva Morais 2006).

A partir destas características iniciais, Ana Frazão (2015) procurou, assim, destacar quatro aspectos essenciais desta modalidade, a partir dos quais é possível identificar a existência de uma joint venture entre as empresas relacionadas. São elas: (i) a existência de um fim comum; (ii) o compartilhamento de risco entre os co-ventures; (iii) a criação de uma interdependência organizativa que permita acompanhar, executar e monitorar a realização da atividade assumida pelas partes, que se dá tanto por alterações societárias ou contratual e (iv) a criação de um novo centro de controle da atividade empresarial.

O "fim comum" é o objetivo, expressa ou tacitamente, convencionado no contrato, que apresenta eficácia funcional entre as contratantes, isto é, constitui um critério que orienta a política da empresa em comum, que se traduz na concretização dos direitos e obrigações das partes. A determinação do "fim comum" é preponderante para o dever de lealdade entre os contratantes (Lima Pinheiro 2003, p. 138), uma vez que estabelece entre as partes uma solidariedade de interesses, em que as vantagens de um são as vantagens do outro (Silva Morais 2006, p. 178-182).

Sobre a identificação do fim comum, Ana Frazão (2015) esclarece que este fim não significa necessariamente a execução comum de uma atividade econômica; o propósito em comum também pode abranger a execução de atividades complementares em que cada contratante faz a sua parte, mas compartilhando sempre de um objetivo econômico que a ambas se aproveita.

Como desdobramento imediato do "fim comum", o segundo elemento distintivo das joint ventures diz respeito à assunção comum do risco empresarial, tendo em vista que tal circunstância é inerente à própria ideia de empresa comum. A consecução de um escopo em comum requer, necessariamente, uma manifestação de vontade das partes em cooperar ativamente para um resultado específico, sempre numa situação de igualdade de participação nestes resultados. Daí porque a disposição das contratantes em arcar com lucros e prejuízos decorrentes da atividade desenvolvida conjuntamente é uma consequência direta da existência de um escopo em comum entre elas.

O terceiro aspecto característico de uma joint venture é o elemento organizacional da relação, isto é, a existência de uma estrutura estável de organização de fatores produtivos, 
normalmente desenvolvida no plano jurídico através de uma universalidade de bens ou direitos. É a dimensão da organização que permite congregar diversos elementos necessários para o alcance das finalidades econômicas. Sem tal dimensão, a durabilidade dos projetos estaria comprometida.

Esclarece Luis Domingos Silva Morais (2006, p. 175) que é justamente esse elemento jurídico que separa as joint ventures das múltiplas modalidades de acordos de cooperação, uma vez que consiste na individualização de uma organização jurídica, criada ex novo, com verdadeiras características empresariais, mesmo que o seu grau de autonomia em relação às empresas fundadoras possa ser relativamente variável. O doutrinador português enfatiza:

A criação de uma específica estrutura organizativa de um feixe de relações de cooperação, dispondo de alguns meios próprios para o efeito - orientada para a realização de um projecto empresarial, mesmo que essencialmente instrumental das atividades das empresas-mãe, que confere à figura da empresa comum ("joint venture") aquele grau mínimo de intensidade e estabilidade do núcleo relacional de cooperação, que a separa tipicamente de meros acordos de colaboração (Silva Morais 2006, p. 175).

Em relação ao grau de intensidade organizacional, é preciso considerar que para a constituição de uma joint venture não basta apenas uma mera governança obrigacional da relação interempresarial. A formação de uma joint venture requer necessariamente um contrato organizativo entre as partes, isto é, uma estrutura minimamente estável entre as contratantes (Silva Morais 2006, p. 176), que procura disciplinar a utilização dos bens a que se refere, bem como disciplinar o movimento paralelo de pessoas e recursos investidos para a realização de um resultado prático (Lima Pinheiro 2003, p. 132), a exemplo da criação de um centro de receitas e despesas relacionado à atividade desenvolvida em conjunto (Lima Pinheiro 2003, p. 60-83). Deste modo, a joint venture requer uma "cooperação organizada" que se diferencia de uma mera "cooperação obrigacional” (Lima Pinheiro 2003, p. 83-162).

Luis Domingos Silva Morais (2006, p. 297) esclarece, todavia, que, na hipótese de uma organização estabelecida em bases meramente compromissórias, haverá a necessidade de desenvolver um sistema complexo de relações obrigacionais que possam introduzir aspectos de integração entre as empresas relacionadas compatíveis com a necessidade de execução, acompanhamento e prestação de contas inerentes ao exercício de uma empresa comum. A integração empresarial é um aspecto inerente às joint ventures, uma vez que a solidariedade de interesses e a simetria de participação no resultado da atividade são características também 
presentes nessa modalidade de relação (2006, p. 178). Vale reproduzir, nesta linha, as lições de Luís de Lima Pinheiro em várias passagens de sua obra:

"Ora, na maior parte dos casos, a cooperação de empresas para a realização de um empreendimento comum tem um certo grau de organização, mesmo que esta não constitua o substrato de uma pessoa coletiva. Este grau é muito variável: indo desde a instituição de meros órgãos de coordenação e (ou) fiscalização até aquelas formas de organização que são características das sociedades de pessoas (...)”. (2003, p. 60-61)

"A maioria dos contratos de cooperação interempresarial institui diretamente uma organização de coordenação de atividades que as empresas comuns devem desenvolver para a realização do projeto comum. Prevê-se o funcionamento de comitês ou comissões, embora nem sempre se definam expressamente as suas competências". (2003, p. 98)

"Já o joint venture, inspirado em 'experiências próprias dos sistemas de common law', seria uma forma de cooperação utilizada para prestações indivisíveis (por natureza ou vontade das partes), em que as partes executam o contrato conjuntamente, repartindo os lucros ou as perdas segundo quotas pré-fixadas, que não são necessariamente referidas a quotas dos trabalhos materialmente exigidos das empresas. $\mathrm{O}$ joint venture requereria um centro de imputação de custos e receitas." (2003, p. 80)

"Tem sido assinalado pelos autores que em regra as partes, além de realizarem as suas contribuições de capital, apoiam a empresa comum com respeito a aspectos administrativos, á dotação de recursos humanos, financiamento, abastecimento de matérias-primas, comercialização dos produtos, tecnologia e assistência técnica, designadamente". 92003, p. 81)

Por fim, o último aspecto característico das joint ventures diz respeito à criação de um novo centro de gestão da empresa em comum, o qual pode se dar tanto pelo controle comum ou compartilhado ou ainda quando apenas uma das contratantes assume a direção da atividade empresarial desenvolvida em conjunto. Quanto a este último aspecto, Bucley e Casson (1999, p. 411) demonstram que, ao analisar casos reais de joint ventures, é possível observar que em muitos deles apenas uma das contratantes assume a direção da empresa comum, enquanto o outro assume um papel passivo (sleeping role).

Deste modo, é possível observar que a formação de uma joint venture é invariavelmente marcada pela criação de um novo centro de poder empresarial, seja mediante um controle que será compartilhado entre os contratantes, seja por meio de um controle que será exercido por apenas um dos contratantes em face do outro, sempre dando ensejo, portanto, a uma nova unidade empresarial distinta daquela previamente existente entre as contratantes. 
Isso significa que, por meio do contrato de joint venture, os participantes mantém sua independência econômica e financeira, porém, estabelecem um estrutura organizativa própria que possibilite o compartilhamento dos riscos da atividade desenvolvida em conjunto. Consequentemente, em razão da estrutura organizativa criada, podem decorrer novas formas de controle das atividades das partes contratantes, resultando alterações nas estruturas do mercado onde atuam.

Daí por que acertadas as conclusões da Conselheira Ana Frazão ${ }^{48}$ no sentido de que as joint ventures podem ser efetivamente consideradas como atos de concentração por envolverem uma efetiva agregação do poder empresarial sobre a empresa comum. Isto é, as joint ventures, ainda que sejam modalidades de cooperação empresarial, devem ser consideradas alternativas às operações de compenetração societária, como a fusão e a incorporação, uma vez que, na medida em que sempre resultam na criação de um novo centro de decisões - seja ele compartilhado entre as partes ou exercido por uma delas sobre a outra -, anulam as relações de concorrência entre os contratantes no que diz respeito à atividade conjunta, interferindo, assim, na estrutura do mercado onde atuam.

Isso significa que, embora não se ajustem perfeitamente às hipóteses clássicas de concentração empresarial, as joint ventures têm levado a efeitos semelhantes no que concerne à constituição de um centro de comando empresarial e, consequentemente, à formação ou à agregação do poder de mercado dos contratantes. Neste sentido, as joint ventures são modalidades de concentração por cooperação, porque, mesmo mantendo a individualidade das partes contratantes, são alternativas às formas usuais de aquisição de poder de controle ou influência dominante sobre a empresa comum (Lima Pinheiro 2003).

Como visto no capítulo anterior, o atual substrato econômico deflagrou um processo de desagregação da empresa hierarquizada e a consequente importância de soluções contratuais intermediárias entre esta e o mercado, conhecidas como "terceira via". Neste cenário, a joint venture assume especial relevância, principalmente na modalidade contratual, uma vez que a criação de uma nova pessoa jurídica tem alcance limitado diante das novas circunstâncias econômicas.

Todavia, é certo que, em razão da multiplicidade dos arranjos contratuais que se encontram no meio empresarial, nem sempre será fácil fazer a distinção entre a universalidade de contratos que se encontram na terceira via daqueles que realmente são relevantes para o

\footnotetext{
${ }^{48}$ Voto-vogal Conselheira Ana Frazão proferido no julgamento do ACs Monsanto em 2013.
} 
direito concorrencial das estruturas, ou seja, daqueles que ensejam formas de concentração por cooperação, tais como os contratos de joint venture.

Muitos contratos, além de adotarem nomes e estruturas atípicas, combinam, de forma relativamente equilibrada, elementos associativos e de troca, de forma que ficariam em uma espécie de zona fronteiriça (Frazão 2015) entre os contratos de joint venture e os demais contratos que não são objeto de incidência do controle preventivo, mas que, no entanto, são capazes de alterar as estruturas do mercado onde se inserem.

É justamente nestes casos onde se encontram os maiores desafios do direito concorrencial brasileiro com relação aos contratos associativos, uma vez que tais contratos, que também se encontram na "terceira via", ainda carecem de delimitação material mais consistente, principalmente no que diz respeito a sua sujeição ao controle preventivo estabelecido pela Lei n. 12.529/2011.

\subsection{UMA TENTATIVA DE DELIMITAÇÃO DO NÚCLEO PRÓPRIO DOS CONTRATOS ASSOCIATIVOS}

Como visto ao longo do capítulo anterior, na organização da atividade econômica contemporânea, não se pode mais conceber a empresa e o mercado de forma isolada; é preciso reconhecer o papel essencial desempenhado pelas cooperações empresariais.

Como vem sendo ressaltado ao longo do trabalho, a vinculação entre as unidades empresariais já não se faz em termos de participação societária de capital, mas adota antes a forma de contratos estáveis, fenômeno este conhecido como um processo de contratualização da atividade empresarial. O mercado identifica-se, assim, como um emaranhado de contratos mercantis tecidos pelos agentes econômicos (Forgioni 2011, p. 25).

Neste cenário, é preciso introduzir os contratos associativos à categoria dos contratos mercantis, procurando situar e justificar a sua existência nos quadrantes do direito privado, para então compreender as suas características e relevância para o direito da concorrência.

\subsubsection{RELAÇÕES CONTRATUAIS E AS FORMAS DE ORGANIZAÇÃO DA ATIVIDADE EMPRESARIAL}

Como visto no segundo capítulo, é possível identificar, entre as formas extremas de organização da atividade econômica, situações intermediárias em que as relações interempresariais assumem elementos da hierarquia empresarial, assim como elementos 
flexíveis das relações de mercado. Trata-se, justamente, das hipóteses em que essas relações se dão por vínculo contratual, e não por vínculo societário.

Segundo Paula Forgioni (2011, p. 183), a zona intermediária existente entre as formas "puras" de organização da atividade econômica é marcada por uma ampla variedade de contratos que envolvem um grau de colaboração maior do que aquele que normalmente existe nas relações de mercado - a qual se traduz em contratos comutativos, de troca ou bilaterais -, porém menor que os contratos de sociedade - que corresponde ao modelo hierárquico de organização da atividade econômica.

Ainda segundo a autora, as formas extremas de organização da atividade econômica se traduzem, de um lado, nos "contratos comutativos", "bilaterais (sinalagmáticos)", "troca/permuta" ou "intercâmbio", e, de outro, os "contratos de sociedade". Por sua vez, os contratos situados na zona intermediária das formas extremas de organização da atividade econômica, recebem as seguintes denominações: "contratos híbridos", termo empregado pela autora Paula Forgioni (2011, p. 183) ou “contratos relacionais", segundo a definição do economista Williamson (1985;1999).

Os contratos bilaterais, comutativos, de troca ou intercâmbio representam o extremo onde predominam as relações de mercado. Todos eles exprimem juridicamente uma troca, em que cada uma das partes realiza prestações dirigidas no essencial à outra parte e tem natureza de contrapartida (Silva Morais 2006, p. 273), isto é, traduz-se na troca de uma prestação. Cumprida uma prestação torna-se exigível a contraprestação, e uma vez extintas prestação e contraprestação - encerra-se o contrato em razão do seu cumprimento total.

Ademais, tais contratos estão condicionados a uma atuação egoística de cada uma das partes. São contratos que pressupõem interesses divergentes e contrapostos entre as contratantes, em que os interesses estão direcionados à maximização do seu próprio benefício, já que nestas relações o incremento da vantagem econômica de uma parte leva à diminuição do proveito da outra (Forgioni 2011, p. 155). São contratos que servem, portanto, à composição da contraposição de interesses existente entre as partes.

Já no extremo oposto, o contrato de sociedade empresária distingue-se fundamentalmente dos primeiros pela existência de interesses convergentes entre as contratantes, em prol de um objetivo comum. Os contratos característicos das relações de mercado pressupõem vontades antagônicas e divergentes entre as partes relacionadas, o que não ocorre numa sociedade. São também elementos fundamentais à efetivação de uma 
sociedade, além da existência de um fim comum, a necessária contribuição dos sócios em esforços e recursos que são comuns e a relação de um poder hierárquico.

O escopo em comum é o elemento decisivo nos contratos de sociedade, o qual impõe às partes contratantes a aceitação da alea comum do negócio. Em termos objetivos, o fim comum traduz-se na partilha obrigatória dos lucros e perdas geradas pela atividade. Especialmente no que concerne a este último, Fabio Konder Comparato (1990, p. 153) entende que é justamente na participação dos sócios nos resultados deficitários do negócio em que reside a característica própria das sociedades empresárias. ${ }^{49}$ Tanto é assim que o Código Civil Brasileiro, no que diz respeito aos contratos de sociedade, estabelece que "é nula a estipulação contratual que exclua qualquer sócio de participar dos lucros e das perdas" (artigo 1008) resultantes do exercício da atividade.

Outro elemento característico dos contratos de sociedade é a existência de comando hierárquico, o que poderia ser comparado a uma relação existente entre mestre/servo ou empregado/empregador (Coase 1999, p. 53). Isto significa que os contratos de sociedade possibilitam a organização do poder de forma institucional (Comparato e Salomão Filho 2014, p. XIII), por meio de um centro de decisões do qual emanará a vontade da empresa.

As características das relações contratuais muito se aproximam das características do sistema clássico de direito contratual descrito por Willianson (1999). É certo que toda relação contratual tem por intuito facilitar as transações comerciais. Não obstante, esse intuito é alcançado, no sistema clássico, através do reforço da singularidade e da intensificação da "presença” ("presentiation”), compreendida como os esforços de fazer-se presente no lugar ou tempo para que a causa seja percebida ou realizada no presente, isto é, há uma participação das empresas em todo o processo de execução da atividade.

Não obstante, inúmeros problemas estão relacionados às formas extremas de relação contratual. Williamson (1999, p. 171) aponta, dentre eles que: (i) nem todas as contingências do futuro podem ser antecipadas no início das negociações; (ii) as devidas adaptações para muitas das contingências não serão evidentes até que as circunstâncias se materializem; (iii) a contratação entre partes autônomas é normalmente difícil e gera grandes disputas, especialmente, considerando que o comportamento delas será sempre oportunístico.

\footnotetext{
${ }^{49}$ Paula Forgioni cita, por exemplo, os contratos de disbribuição em que pode haver uma interdependência do sucesso empresarial entre fornecedor e distribuidor, mas isso não significa que haverá uma assunção do eventual prejuízo entre eles. Daí porque o contrato de distribuição não seria propriamente um contrato de sociedade (Forgini 2008, p. 100).
} 
Neste contexto, uma forma diferente de relação contratual, que permita preservar a flexibilidade das transações, mas que preveja uma estrutura de governança adicional para lidar com as incertezas do mercado, passa a ser idealizada. Neste perspectiva, as associações empresariais que se dão por meio de "contratos híbridos" (ou "contratos relacionais" de acordo com o conceito empregado pelo economista) ganham destaque no cenário de organização da atividade empresarial.

A expressão “contratos híbridos” é utilizada por Paula Forgioni (2011, p.154) para definir os contratos de entremeio situados entre a empresa e o mercado, e explica a dificuldade enfrentada em lidar com essas novas formas de organização da atividade econômica:

\begin{abstract}
"O entendimento desses dois polos [referindo-se às sociedades comerciais e aos contratos de intercâmbio] é também importante para que se tenha a real dimensão dos problemas dos contratos "de entremeio" e que derivam, principalmente, da ausência de respostas jurídicas a vários impasses que surgem durante a sua execução. Se, no que toca ao intercâmbio e às sociedades, essas soluções foram sendo construídas com o passar do tempo e hoje são conhecidas dos juristas, o mesmo não ocorreu com os "híbridos" até porque a disseminação de seu uso é fenômeno recente."
\end{abstract}

Acrescenta Paula Forgioni (2011, p. 183) que "o grau de autonomia das partes nas formas híbridas é mais acentuado do que nos modelos hierárquicos, porém inferior ao da solução de mercado".

No mesmo sentido, a expressão “contratos relacionais" é utilizada pelo economista Willianson (1999) para tratar das situações nas quais os contratantes mantêm a sua autonomia, mas estabelecem entre eles um relacionamento mais estável com base em elementos diferenciados de cooperação. Isto é, são contratos específicos de longa duração em que as partes, mais do que estabelecer as obrigações recíprocas, precisam estruturar, minimamente, um sistema de governança que possibilite, manter a continuidade e adaptabilidade em face das modificações futuras do mercado.

Os contratos relacionais, tais como os contratos híbridos, não resultam necessariamente na integração entre os contratantes, pois, apesar de haver certa interdependência entre as partes, elas mantêm a autonomia com relação ao patrimônio, às atividades, aos lucros e aos prejuízos de cada uma (Forgioni 2011, p. 173). 
Alguns tipos contratuais que assumem forma hibrida são: contratos de mera colaboração ${ }^{50}$, contratos de execução continuada ou contratos comutativos de longa duração, tais como contratos de distribuição, contratos de fornecimento, contratos de licenciamento, contratos de franquia. Nesses contratos, é possível identificar algum elemento cooperativo entre as partes, que não chega, entretanto, a traduzir-se em uma identidade de propósitos entre os contratantes (Frazão 2014, p. 12) (Forgioni 2008, p. 77).

Os contratos híbridos ou relacionais são, portanto, contratos de cooperação empresarial, porque, longe de constituírem transações pontuais de bens e serviços, criam laços estáveis ou duradouros entre os contratantes. Os contratos relacionais dependem de uma cooperação direcionada para o futuro, não apenas para garantir o cumprimento do que foi firmado, mas também para o planejamento extensivo das atividades substantivas da relação (Forgini 2008, p. 73).

Manter a confiança é, portanto, elemento central dos contratos relacionais ou híbridos. Sendo assim, os contratos comutativos de execução continuada ou de longa duração, em virtude da sua conformação, que pressupõe a organização de um programa continuado e diferido no tempo entre as partes relacionadas, incorporam necessariamente elementos reforçados de confiança (Silva Morais 2006, p. 277), e, consequentemente, acabam deslocando-os do extremo das relações de mercado para a zona intermediária dos contratos híbridos. Aliás, como ressalta Luís Domingos Silva Morais (2006, p. 289), na praxis das relações contratuais esta bifurcação não se apresenta, em regra, de modo linear. Deste modo, sempre haverá uma dificuldade por parte da autoridade de apurar categorias de contratação em que ora o elemento comutativo, ora o aspecto cooperativo sejam mais prevalecentes.

Entre os contratos híbridos, é possível identificar formas de cooperação ainda mais qualificadas, na medida em que dispõe de organização própria para alcançar um fim comum entre as partes contratantes. A exemplo, como visto anteriormente, dos contratos de joint venture, cuja característica principal reside na criação de uma estrutura organizativa que permita acompanhar, executar e monitorar a realização de um fim comum assumido pelas partes.

A figura abaixo procura demonstrar a localização dos contratos relacionais ou híbridos entre as formas extremas de organização da atividade empresarial:

\footnotetext{
${ }^{50}$ São contratos em que as partes vinculam-se a uma certa coordenação das suas atividades, mas não se obrigam a colaborar na prossecução de um resultado econômico unitário (Lima Pinheiro 2003, p. 209).
} 


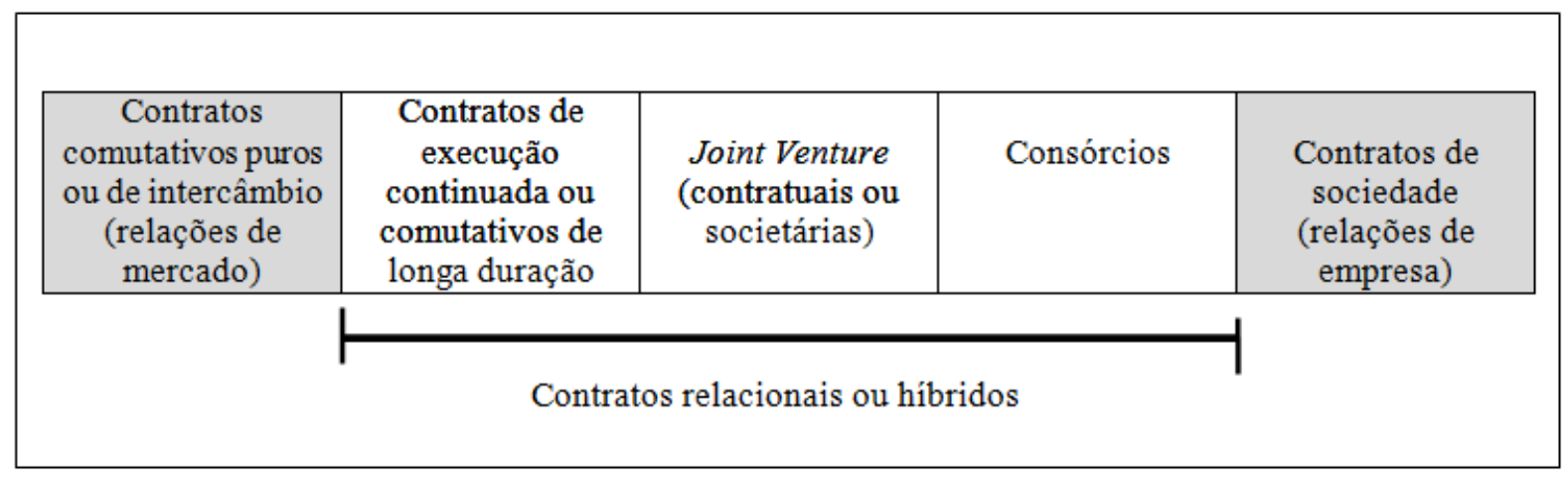

Fig.2. - Contratos relacionais ou híbridos

Neste contexto, diante da multiplicidade de contratos relacionais e híbridos normalmente pactuados entre os agentes econômicos, é preciso encontrar critérios para distinguir entre eles o que seriam os contratos associativos para fins de aplicação do artigo 90 da Lei n. 12.529/2011.

\subsubsection{CONTRATOS ASSOCIATIVOS PARA FINS DE APLICAÇÃO DA LEI N.12.529/11}

A expressão "contrato associativo" não encontra expressão consistente no direito brasileiro, mas no direito e na doutrina italiana é um termo bastante comum. Segundo o entendimento difundido na Itália, "contratos associativos" é espécie do gênero dos contratos plurilaterais.

O contrato associativo se assemelha ao contrato plurilateral em razão do aspecto funcional e causal da comunhão de escopo (Sabetta 2009, p.14) ${ }^{51}$. A comunhão de propósitos é a própria razão de ser do contrato e pode ser perceptível em todos os seus elementos: na origem, no desenvolvimento e nos resultados da relação, mantendo sempre a paridade ente os participantes no concurso pela participação nos resultados.

O contrato associativo persegue, portanto, um escopo comum aos contratantes; e tal escopo consiste no desenvolvimento de uma atividade. A identidade de escopo é, desta

\footnotetext{
${ }^{51}$ Quanto ao aspecto diferencial, esclarece Sabetta que: Se la necessaria e inderogabile pluralità delle parti contrassegna, sotto l'aspetto strutturale, il contratto plurilaterale, è facile avvertire che, con la nozione di contratto associativo, non è affatto incompatibile la dualità delle parti; anzi in certe sue desuete applicazioni (contratti agrari) il contratto associativo poteva avere soltanto due parti. A parte ciò, esso può indifferentemente avere due parti o più di due, laddove il contratto plurilaterale non può avere meno di tre parti senza contraddire l'art. 1420. Dove invece contratto plurilaterale e associativo collimano in toto è nel dato funzionale, o causale, della comunione dello scopo (Sabetta 2009, p. 14).
} 
forma, uma exigência funcionalística do contrato que chega a se confundir com a sua própria causa (Barra 2010, p.541).

No direito brasileiro, o conceito de contratos plurilaterais teve sua maior expressão para designar o caráter contratual do ato constitutivo da sociedade empresária, em que a comunhão de fim é essencial para a consecução do escopo contratual. Nos contratos plurilaterais, o escopo constitui o interesse comum e unificador das várias partes contratantes e concorre para determinar o alcance dos direito e dos deveres de cada uma delas. Segundo Tullio Ascarelli (1969, p.271):

À pluralidade corresponde a circunstância de que os interesses contrastantes das várias partes devem ser unificados por meio de uma finalidade comum; os contratos plurilaterais aparecem como contratos com comunhão de fim. Cada uma das partes obriga-se, de fato, para com todas as outras, e para com todas as outras adquire direitos; é natural, portanto, coordená-los, todos, em torno de um fim, de um escopo comum.

Daí o entendimento de estudiosos italianos de que o significado do contrato associativo é a generalização do tipo de contrato de sociedade (Sabetta 2009, p. 14). Nesta linha também é o entendimento de doutrinadores portugueses como Luis Lima Pinheiro (2003, p. 129). Contrato associativo é, portanto, contrato de comunhão de fim, que tem, primordialmente, por intuito, disciplinar a utilização dos bens a que se refere, coordenando as diversas partes contratantes em torno desse fim (Frazão 2015). Tal como nos contratos plurilaterais, o escopo contratual dos contratos associativos é juridicamente relevante e determinante para às atividades posteriores a que se destina. Com efeito, diversamente do que ocorre nos contratos comutativos/bilaterais, em que o fim prende-se a execução da própria contraprestação, nos contratos associativos há uma preocupação de coordenação dos contratantes para possíveis fatos ou atos posteriores relacionados ao alcance do objetivo contratual (Frazão 2015).

Com efeito, explica a Conselheira Ana Frazão $^{52}$ que a mera referência à cooperação ou colaboração não é suficiente para definir os contratos associativos, uma vez que, até mesmo por influência da cláusula geral da boa-fé objetiva contratual ${ }^{53}$, pode-se

\footnotetext{
${ }^{52}$ Voto-vogal da Conselheira Ana Frazão no AC Monsanto julgado em 2013, p. 15.

53 A cláusula geral de boa-fé traz aos contratos e aos negócios jurídicos deveres anexos para as partes: de comportarem-se com a mais estrita lealdade, de agirem com probidade, de informarem o outro contratante sobre todo o conteúdo do negócio. Nesse tom, a colaboração está presente de forma inequívoca. Sob esse prisma, o enunciado número 24 do Conselho Superior da Justiça Federal, aprovado na I Jornada de Direito Civil, realizada em setembro de 2002, prevê que o desrespeito desses deveres anexos gera a violação positiva do contrato,
} 
considerar que a cooperação é um aspecto comum a todos os contratos. O aspecto distintivo dos contratos associativos não reside, portanto, na existência ou não de cooperação, mas sim no grau e na forma como ela é exercida entre as partes relacionadas (Frazão 2015).

As formas de cooperação abarcam uma multiplicidade de contratos relacionais e híbridos normalmente pactuados entre os agentes econômicos, que variam desde a constituição de joint ventures societárias até contratos comutativos de longa duração. Deve haver, portanto, um critério que permita separar os casos de mera cooperação dos casos que envolvem efetivamente a realização de um contrato associativo. O critério que se observa, para o caso, é a existência de um escopo em comum entre as partes ${ }^{54}$. Isso explica porque os contratos de longa duração não são, por esta única característica, contratos associativos, já que podem não traduzir a existência de um objetivo em comum entre as partes relacionadas.

É justamente neste aspecto onde reside a principal dificuldade da autoridade antitruste. Isso porque a expressão “contratos associativos" encerra uma irremediável

espécie de inadimplemento a imputar responsabilidade contratual objetiva àquele que viola um desses direitos anexos.

54 A qualificação do escopo comum entre as partes é fundamental, inclusive, para distinguir os contratos associativos de formas de cooperação ilícitas, como o cartel, por exemplo, que não deixa de ser uma associação empresarial em sua essência. A Teoria norte-americana do Ancilary Restraints - doutrina da restrição acessória traz critérios que possibilitam distinguir os tipos de acordos de cooperação empresarial que devem ser submetidos a controle de estrutura daqueles que devem ser submetidos ao controle repressivo. Segundo esta teoria, compromissos que, em si mesmos, poderiam ser tidos como restritivos da concorrência, mas que se mostrem condições essenciais ou necessárias para determinada transação, que não tenha por objeto restringir a concorrência, não devem ser incluídas no âmbito das proibições per se. Isso significa que quando a restrição a concorrência configurar objeto secundário do acordo e não principal, este acordo estará sujeito ao controle preventivo, para que as autoridades possam examinar os efeitos líquidos do ato e decidir por sua aprovação ou não. Caso contrário, em se tratando do elemento principal da associação, o acordo será per se ilícito e, por conseguinte, sujeito à incidência do controle repressivo do antitruste. É possível observar que a causa contratual - entendia como a função do contrato - permite identificar um núcleo de aspectos regularmente presentes nos contratos associativos que o diferem das formas ilícitas de associação. Os acordos materialmente estruturados como cartéis não apresentam qualquer justificativa se não a mera fixação do preço, do volume de produção ou do mercado de atuação - intrinsicamente restritivas da concorrência - e, em razão disso, apresentam um grande desvalor jurídicos. Já os contratos associativos apresentam uma valoração jurídica positiva na medida em que a restrição da concorrência é um elemento meramente acessório e não principal do acordo.

Isso significa que, ainda que não haja uma delimitação clara das formas de cooperação sujeitas ao controle prévio daquelas sujeitas ao controle repressivo, é possível observar, a partir de uma certa repetição de esquemas consolidados, que tais operações apresentam características igualitárias e equilibradas, cujas cláusulas de governança são distintas daquelas que estão presentes nos contratos sinalagmáticos (Frazão 2014, p. 17), a exemplo dos cartéis. Tanto é assim que Salomão Filho (2013, p. 137) afirma que: "À parte a imprecisão terminológica na definição da fattispecie, consistente em denominar "concentração" à operação de cooperação econômica, a distinção entre disciplina de joint venture e associações, de um lado (controle de estruturas), e acordos puros, de outro (controle das condutas), é correta. Enquanto os primeiros podem ter objetivos outros que não única e exclusivamente a definição de variáveis concorrenciais, os acordos puros entre concorrentes referemse diretamente a estas, e, portanto, exigem avaliação pura e direta de licitude ou ilicitude".

Diferentemente dos cartéis, acordo de cooperação ilícito, os contratos associativos não dirigem exclusivamente à regulação do comportamento concorrencial das partes, como se verifica, por exemplo, com os acordos de fixação de preço, divisão de mercado ou de restrição da produção. A função dos contratos associativos é mais complexa e positiva (Pinheiro 2003, p. 165), como já visto no segundo capítulo. 
ambiguidade: ela evoca associação, mas tende a abranger relações contratuais de cooperação sem organização formal, isto é, contratos de eficácia meramente obrigatória (Pinheiro 2003, p. 162), sem qualquer elemento organizacional próprio entre as empresas, o que dificulta a identificação de critérios que possam apontar a existência de escopo comum entre as partes relacionadas 55 .

As cooperações meramente obrigacionais abarcam justamente aquelas situações jurídicas-econômicas em que há uma conjugação de atividades estabelecida entre as partes, mas que não chega a materializar um suporte organizacional próprio ${ }^{56}$. Deste modo, neste tipo de relação, a atividade das partes se dará por meio de prestações individualizadas de cada uma, sem a mediação de um suporte institucionalizado para tanto.

Contratos associativos apresentam, nesta linha, características semelhantes, se não iguais, das joint ventures contratuais nos termos propostos por Luís de Lima Pinheiro (2003), para quem a joint venture caracteriza-se como um contrato de empreendimento comum e, como tal, corresponde a uma denominação jurídica precisa de atividades econômicas prosseguidas em comum e que não pressupõe necessariamente a constituição de uma organização comum, podendo, pelo contrário, assentar em meras relações obrigacionais. Assim, tal como nos contratos de joint venture, os contratos associativos correspondem a um conjunto encadeado de relações obrigacionais entre as empresas participantes, conformando um processo permanente de cooperação, dirigido à realização de uma atividade empresarial conjunta, o qual poderá ou não assumir a forma de uma plataforma organizacional devidamente institucionalizada (Lima Pinheiro 2003, p. 197).

Como bem explica Luis Domingos Silva Morais (2006, p. 173), as alternativas a configuração dos contratos associativos, que se da em base de compromissos contratuais, são muito variadas. Observa ele que a cooperação obrigacional pode abarcar desde práticas concertadas que não atendem aos requisitos de validade do negócio jurídico até acordos

\footnotetext{
55 O conceito de contrato associativo se aproxima com o amplo conceito de joint ventures contratuais desenvolvido por Friedmann-Béguin (apud Lima Pinheiro 2003, p. 80), segundo o qual contractual joint venture seria qualquer empreendimento em que havendo a assunção comum do risco econômico, não se forma uma empresa comum com personalidade jurídica distinta. Com efeito, seria joint venture contratual quer se trate de uma mera relação obrigacional ou disponha de uma organização sem personalidade jurídica.

${ }^{56}$ Veja que isso não passou desapercebido pelo legislador brasileiro. Isso porque, nas disposições do art. 90, ao fazer uma distinção entre (i) contratos associativos, (ii) Joint ventures (societárias ou contratuais) e (iii) consórcios, parece que o legislador reservar aos contratos associativos todas aquelas hipóteses remanescentes que não se encaixam propriamente no conceito apresentado de joint venture e consórcio. Deste modo, uma das distinções entre elas seria o elemento organizacional, que nos contratos associativos pode ser mais flexível ou até mesmo inexistente entre as partes relacionadas
} 
desprovidos no todo ou em parte de vinculatividade jurídica, a partir de conteúdos de natureza genérica dos quais decorram mera influência de comportamento, sem verdadeiro caráter cogente ${ }^{57}$.

É por tal razão que esta modalidade jurídica em muito se confunde com os contratos comutativos de longa duração, já que aparentam envolver um conjunto de situações esporádicas de convergência dos interesses empresariais próprios de cada participante (Silva Morais 2006, p. 306). Necessário, portanto, fazer uma distinção das relações de cooperação obrigacional mais difusas e assentes em meros contratos comutativos daquelas relações mais estáveis, de tipo associativo, conquanto sem uma verdadeira componente organizacional (Silva Morais 2006, p. 307). Com efeito, contratos aparentemente comutativos perdem essa natureza por estabelecer uma forma de cooperação qualificada pela existência de um escopo em comum entre as partes relacionadas, dando, assim, ensejo aos contratos associativos. A identificação do escopo comum nestes casos não é uma tarefa trivial, mas poderia se dar a partir de elementos comportamentais que possam afastar o caráter puramente comutativo do contrato.

A figura 3 abaixo procura situar os contratos associativos em relação aos contratos relacionais estudados no item anterior, e sua consequente localização entre as formas extremas de organização da atividade empresarial:

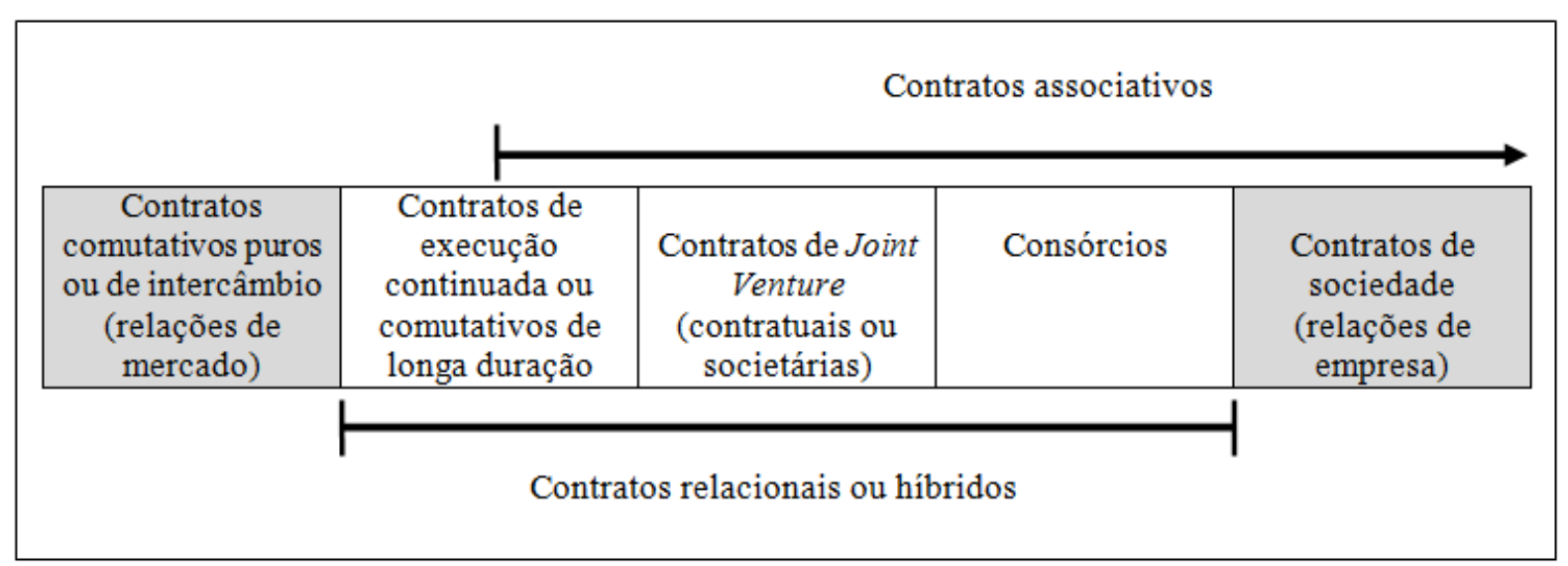

Fig.3. - Contratos associativos

Nota-se, pela figura, que contratos associativos podem envolver relações contratuais que não se amoldam perfeitamente nos conceitos de joint venture e consórcio. Esse entendimento se justifica uma vez que os contratos empresariais cada vez mais se

\footnotetext{
${ }^{57}$ Esse aspecto foi identificado no caso Monsanto recentemente julgado pelo CADE, como ser verá no último capítulo dessa dissertação.
} 
mostram longos, confusos e complexos, muitas vezes ocultando a existência de uma estrutura organizativa mais definida justamente para se furtar a incidência dos dispositivos legais, ou ainda, quando apresentam nomes e títulos que não refletem adequadamente seu verdadeiro conteúdo, exigindo do intérprete um esforço adicional para identificar a real natureza do contrato.

Contrato associativo é, portanto, qualquer relação contratual que apresente: (i) uma cooperação estável e (ii) um escopo comum entre as partes relacionadas. Nestes contratos, na medida em que as partes se associam para lograr um fim comum, é possível verificar que as suas necessidades são as mesmas ou muito próximas, havendo entre as contratantes uma solidariedade de interesses em que as vantagens de uma são as vantagens da outra. Por tal razão, entende-se que o fim comum estabelece uma forma de integração empresarial, resultando, assim, em uma unidade empresarial no que se refere ao objetivo em comum.

Resta claro, portanto, que, independentemente da delimitação precisa do conceito de contratos associativos para efeitos de direito da concorrência, e desde que se afastem definições latíssimas desta figura que diluem sua autonomia conceitual e a relevância da sua função de enquadramento para o direito da concorrência, esta categoria incorpora no seu núcleo processos de integração empresarial. Isto é, ainda que não resultem na total extinção da individualidade das empresas participantes, envolvem, paralelamente, relações estáveis de coordenação entre as mesmas, em termos efetivos, ou, pelo menos, em termos potenciais, a partir de um fim comum estabelecido (Silva Morais 2006, p. 42), dando ensejo, consequentemente, a uma nova unidade empresarial.

Considerando o conceito proposto, os contratos associativos são, portanto, objeto de controle concorrencial de estruturas na medida em que resultam formas de concentração por cooperação.

Como visto no início deste capítulo, as modalidades de concentração por cooperação se dão a partir da existência de uma cooperação qualificada pela existência de um escopo em comum estabelecido entre as contratantes que invariavelmente resultam na formação de uma nova unidade empresarial, em razão da perda da autonomia econômica preexistente entre as partes relacionadas em função do objetivo fixado entre elas.

O domínio específico de apreciação dos contratos associativos, suscita, portanto, uma combinação complexa da análise de elementos do comportamento concorrencial 
(cooperação empresarial) e dos elementos estruturais do mercado, vindo a gerar, desta forma, testes jurídicos-econômicos baseados na possibilidade de estes contratos possibilitar a criação ou reforço do poder de mercado, a partir da formação de uma nova unidade econômica.

É claro que tal tarefa não é simples, porque o próprio reconhecimento da celebração de um contrato associativo ainda encontra inúmeras dificuldades. Como visto anteriormente, os contratos associativos muito se confundem com os contratos relacionais ou híbridos, especialmente quando se trata dos contratos comutativos de longa duração. Isso porque, contratos associativos são, de fato, contratos relacionais, no entanto, apresentam uma natureza mais específica por estabelecer uma forma de cooperação qualificada, qualificada pela formação de um escopo em comum entre as partes relacionadas.

Ocorre que a identificação do escopo comum nestes casos não é uma tarefa trivial e é justamente nesta dificuldade onde a autoridade antitruste encontra seus maiores desafios na execução do controle preventivo.

Explica Luís Domingos Silva Morais (2006, p. 328) que, para efeitos de incidência do direito da concorrência, é necessário identificar uma área na qual, a partir de certo limiar qualitativo, ocorra uma interpenetração de elementos de integração e cooperação empresarial que possa levar a formação de uma nova unidade econômica, dando assim, ensejo a formas de concentração por cooperação. Neste aspecto, mais uma vez, é fundamental o papel da autoridade na identificação de critérios objetivos a partir dos quais seja possível ao menos presumir a existência de um contrato associativo, isto é, de contratos que estabeleçam um escopo em comum entre as parte resultando na formação de uma nova unidade empresarial, que invariavelmente se dá a partir da perda relativa de autonomia econômica entre as partes.

Como se verá no próximo capítulo, um ponto de partida para esta análise seria compreender os contratos associativos a partir de elementos comportamentais que possam afastar o caráter puramente comutativo do contrato, procurando estabelecer, nestes casos, uma combinação de critérios jurídicos de apreciação de formas de coordenação de comportamentos empresariais, indutores de efeitos restritivos da concorrência (Silva Morais 2006, p. 42), a partir dos quais seja possível presumir que as partes estejam atuam como uma unidade empresarial distinta daquela preexistente a operação ${ }^{58}$.

\footnotetext{
${ }^{58}$ Os contratos associativos tem primariamente como intuito a integração e conjugação de recursos na realização de empreendimentos comuns, ou então permitem a execução de atividades econômicas mediante operações
} 


\section{AS REGRAS DEFINIDAS PELO CADE PARA NOTIFICAÇÃO DE CONTRATOS ASSOCIATIVOS}

Como demonstrado no primeiro capítulo, as peculiaridades inerentes ao direito concorrencial - abertura conceitual da legislação e limitação informacional -, acabam reservando um amplo espaço de decisão às autoridades públicas responsáveis por sua aplicação. Deste modo, as autoridades, no caso brasileiro, o CADE, se tornam o principal formulador de regras concorrenciais específicas capazes de definir com maior precisão os limites de incidência da legislação sobre a atuação dos agentes econômicos.

O que se pretende demonstrar neste capítulo é que a as regras definidas pelo CADE a respeito da necessidade de notificação dos contratos associativos ainda estão longe de alcançar consistência política, transparência e objetividade no processo de densificação jurídica do conceito de contratos associativos.

É evidente que as dificuldades na definição e identificação de contratos associativos exigem a incorporação de uma série de considerações dinâmicas, que podem tornar a interpretação dos dispositivos da legislação concorrencial uma tarefa de complexidade intimidadora (Kaplow e Shapiro 2007, 113), em razão dos entraves que normalmente se encontram na identificação dessas situações de forma a priori.

Como bem se sabe a respeito da experiência do direito concorrencial, as impressões resultantes da experiência na apreciação de certas transações comerciais têm influenciado diretamente no processo de formação de novos parâmetros jurídico-econômicos de análise.

É certo que a práxis decisória do Conselho neste domínio conheceu constantes flutuações. Não obstante, é possível identificar uma orientação de fundo caracterizada por uma percepção jurídico-econômica dos possíveis efeitos sobre a concorrência que podem ser desencadeados por determinados aspectos da transação comercial sobre o mercado em questão. Deste modo, é possível fazer uma análise jurídico-formal a partir destas situações,

transmissão e cessão de uso de recursos tecnológicos, de fornecimento de outros fatores produtivos e de distribuição de produtos finais (Pinheiro 2003, p. 165). Ocorre que estas operações muitas vezes requerem um mínimo de estabilidade para viabilizar o negócio e poder melhorar as condições do exercício da atividade. Nestes casos, as formas encontradas para garantir a estabilidade podem gerar restrições ou alterações nas condições de concorrência do mercado. As cláusulas restritivas à concorrência não demonstram, necessariamente, a existência de um escopo em comum entre as parte. No entanto, na medida em que estabelecer uma perda relativa da autonomia entre elas, é razoável presumir que, em razão dessa restrição comumente pactuada, existe um escopo em comum. Os critérios de presunção serão mais bem explorados no último capítulo. 
que permitem, assim, assimilar de modo quase imediato, a possibilidade de formação de uma nova unidade econômica.

Ao analisar a Resolução n 10/2014, recentemente editada pelo CADE, é possível verificar a construção de diferentes standards analíticos voltados a guiar a notificação dos contratos associativos sob o regime do controle preventivo de estruturas. Nestes casos, o CADE adotou uma variedade de regras e princípios, que, no entanto, ainda impossibilitam a formatação de padrões estáveis de investigação e de aplicação da legislação de defesa da concorrência, principalmente no que concerne à preservação do conteúdo próprio daquilo que se entende por "contratos associativos" e "ato de concentração".

Procura-se, com base nessa matriz, equacionar a possibilidade de desenvolvimento de uma metodologia de análise que garanta graus mínimos de previsibilidade e segurança jurídica no tratamento de contratos associativos e que permita delimitar situações a partir das quais é possível identificar a formação de um ente ou propósito comum entre as partes relacionadas que resulte na concentração do mercado. Sobre o controle de estruturas, Ana Frazão (2015a, p. 12) entende que é preciso identificar "elementos de estabilidade, organização e autonomia econômica para distinguir com um mínimo de segurança, dentre as inúmeras relações de cooperação entre as empresas, aquelas que devem constituir o objeto" do controle preventivo.

\subsection{RESOLUÇÃo CADE № 10 DE 04 DE NOVEMBRO DE 2014}

Em março de 2014, o CADE submeteu à consulta pública proposta de Resolução que regulamenta o art. 90, inciso IV da Lei n. 12.529/2011. A proposta apresentava o seguinte teor:

RESOLUÇÃO n ${ }^{\circ} 8$ Disciplina as hipóteses de notificação da celebração de contrato associativo, de que trata o inciso IV do artigo 90 da Lei 12.529 , de 2011. O PLENÁRIO DO CONSELHO ADMINISTRATIVO DE DEFESA ECONÔMICA, no uso de suas atribuições que lhe confere o art. $9^{\circ}, \mathrm{XV}$ da Lei ${ }^{\circ} 12.529$ de 2011, nos termos do art. 53, caput, e do art. 54, inciso I da mesma lei, RESOLVE: Art. $1^{\circ}$ Esta resolução disciplina as hipóteses de notificação da celebração de contrato associativo, de que trata o inciso IV do artigo 90 da Lei n. 12.529 de 2011. Art. $2^{\circ}$ Respeitados os critérios objetivos estabelecidos no art. 88 da Lei $n^{\circ} 12.529$ de 2011, considera-se associativo qualquer contrato celebrado: I - entre concorrentes; ou II - entre agentes econômicos que atuem em mercado verticalmente relacionado, sempre que pelo menos um deles detenha vinte por cento $(20 \%)$ ou mais do respectivo mercado relevante, desde que preenchida pelo menos uma das seguintes condições: a) o contrato estabeleça o compartilhamento de receitas e prejuízos entre as partes; b) do contrato decorra relação de exclusividade, 
seja ela jurídica ou fática. Parágrafo único. Para aferir as relações horizontais e verticais que determinam o enquadramento das operações nos incisos desse artigo, devem ser consideradas as atividades das partes contratantes e das demais empresas integrantes dos respectivos grupos econômicos, conforme definição do artigo $4^{\circ}$ da Resolução $n^{\circ} 2$. Art. $3^{\circ}$ Essa Resolução entra em vigor na data de sua publicação.

Das vinte e três contribuições recebidas na Consulta Pública $n^{\circ}$ 03/2014, todas foram unânimes no sentido de que o conceito proposto para contratos associativos se apresentava muito abrangente e inadequado aos propósitos da Lei. As contribuições pugnavam pela necessidade de outros critérios qualitativos sob pena de gerar a notificação compulsória de contratos ordinariamente realizados na condução dos negócios, insegurança jurídica com relação aos critérios de notificação, engessamento desnecessário da atividade econômica e a ineficiência do serviço público em razão da sobrecarga de processos notificados.

Encerrado o procedimento de consulta pública, a versão final da resolução foi publicada em 04 de novembro de 2014. Segundo os termos da Resolução ${ }^{59}$, os seguintes critérios deverão ser observados cumulativamente para a configuração dos contratos associativos:

59 Resolução n ${ }^{\circ}$ 10, de 29 de outubro de 2014 (publicada no Diário Oficial da União de 04 de novembro de 2014, n 213, seção 1, página 112) Disciplina as hipóteses de notificação da celebração de contrato associativo, de que trata o inciso IV do artigo 90 da Lei n. 12.529, de 30 de novembro de 2011. O PLENÁRIO DO CONSELHO ADMINISTRATIVO DE DEFESA ECONÔMICA, no uso de suas atribuições que the confere o art. $9^{\circ}, \mathrm{XV}$ da Lei n. 12.529 de 2011, nos termos do art. 53, caput, e do art. 54, inciso I da mesma lei, RESOLVE: Art. $1^{\circ}$ Esta Resolução disciplina as hipóteses de notificação da celebração de contrato associativo, de que trata o inciso IV do artigo 90 da Lei 12.529, de 2011. Art. $2^{\circ}$ Respeitados os critérios objetivos estabelecidos no artigo 88 da Lei n. 12.529, de 2011, e para fins do disposto nesta lei, consideram-se associativos quaisquer contratos com duração superior a 2 (dois) anos em que houver cooperação horizontal ou vertical ou compartilhamento de risco que acarretem, entre as partes contratantes, relação de interdependência. $\S 1^{\circ}$ Para fins do disposto no caput deste artigo, considera-se que há cooperação horizontal ou vertical ou compartilhamento de risco que acarretam relação de interdependência: I - nos contratos em que as partes estiverem horizontalmente relacionadas no objeto do contrato sempre que a soma de suas participações no mercado relevante afetado pelo contrato for igual ou superior a vinte por cento (20\%); ou II - nos contratos em que as partes contratantes estiverem verticalmente relacionadas no objeto do contrato, sempre que pelo menos uma delas detiver trinta por cento $(30 \%)$ ou mais dos mercados relevantes afetados pelo contrato, desde que preenchida pelo menos uma das seguintes condições: a) o contrato estabeleça o compartilhamento de receitas ou prejuízos entre as partes; b) do contrato decorra relação de exclusividade. $§ 2^{\circ}$ Para fins dos incisos I e II deste artigo, consideram-se partes contratantes as entidades diretamente envolvidas no negócio jurídico sendo notificado e os respectivos grupos econômicos, conforme definição do artigo $4^{\circ}$ da Resolução $n^{\circ}$ 2, de 29 de maio de 2012. § $3^{\circ}$ Os contratos com duração inferior a dois anos devem ser notificados nos termos desta Resolução quando, mediante sua renovação, o período de 2 (dois) anos for atingido ou ultrapassado. Art. $3^{\circ}$ Esta Resolução entra em vigor após decorridos 60 (sessenta) dias de sua publicação oficial. 
a) o primeiro é a existência de um contrato de longa duração: contrato de duração superior a 2 (dois) anos, considerados, neste requisito, inclusive os contratos com duração inferior mas que, mediante sua renovação, o período de 2 (dois) anos for atingido ou ultrapassado;

b) superada a questão da duração do contrato, para que o contrato seja notificável à autoridade, é preciso que também haja uma relação de cooperação ou de compartilhamento de risco entre as partes relacionadas que leve a uma situação de interdependência entre elas. Nesta linha, a situação de interdependência será considerada somente nas seguintes hipóteses:

I - nos contratos em que as partes estiverem horizontalmente relacionadas no objeto do contrato sempre que a soma de suas participações no mercado relevante afetado pelo contrato for igual ou superior a vinte por cento (20\%); ou

II - nos contratos em que as partes contratantes estiverem verticalmente relacionadas no objeto do contrato, sempre que pelo menos uma delas detiver trinta por cento (30\%) ou mais dos mercados relevantes afetados pelo contrato, desde que preenchida pelo menos uma das seguintes condições:

a) o contrato estabeleça o compartilhamento de receitas ou prejuízos entre as partes;

b) do contrato decorra relação de exclusividade.

A Resolução, que entrou em vigor recentemente, procurou, por um lado, solucionar as dúvidas jurídicas com relação aos termos da Lei, mas, por outro, acabou criando outras tantas. Isso porque, ao procurar trazer uma nova distinção conceptual no propósito de delimitar as regras materiais aplicáveis aos contratos associativos, contraditoriamente, gerou maior indefinição e imprevisibilidade jurídica, além de, paralelamente, gerar uma nova distorção normativa.

\subsubsection{DO REQUISITO TEMPO}

O requisito tempo não foi inicialmente considerado na proposta submetida pelo CADE à Consulta Pública, tampouco foi objeto arguido nas contribuições apresentadas pelo 
público externo à consulta pública realizada. Não obstante, o critério foi posteriormente inserido na versão final da Resolução publicada em novembro de 2014.

Os contratos associativos, enquanto espécie dos contratos relacionais, procuram estabelecer uma continuidade da relação entre as partes, uma vez que a interrupção da relação rompe as condições de segurança e confiança inerentes a estas modalidades contratuais.

Nesta linha, o tempo é um elemento que necessariamente integra os contratos de execução continuada, uma vez que, em face desta característica, as obrigações das partes são renovadas sucessivamente sem que seja modificado o conteúdo das obrigações, porquanto a longa duração contratual é interessante para ambos.

Ademais, para a configuração de um ato de concentração, é necessário que ocorram alterações minimamente permanentes na estrutura do mercado, razão pela qual o prazo contratual é o primeiro elemento de distinção entre os meros contratos comutativos e os contratos associativos, que são objeto de controle preventivo pela autoridade.

Os contratos associativos estão sujeitos ao controle preventivo do CADE, uma vez que eles se revestem de forma minimamente duradoura, não apresentam uma estrutura precária ou vocacionada apenas para a realização de um objetivo imediato. A ideia fundamental subjacente a essa condição corresponde à exigência no sentido de que os contratos associativos sejam capazes de ao menos induzir uma transformação nas relações de concorrência do mercado onde ocorrem, o que requer um mínimo de estabilidade na relação estabelecida entre as empresas.

Nesta linha, foi acertado o entendimento do CADE no sentido de estabelecer o elemento temporal como o primeiro critério a ser verificado a fim de traçar uma linha distintiva entre os contratos comutativos, realizados no curso normal dos negócios empresariais, e aqueles que podem configurar contratos associativos, modalidade de cooperação mais estável e duradoura estabelecida entre empresas para a consecução de um fim comum.

Segundo os termos da resolução, contrato de longa duração é qualquer contrato que estabeleça prazo superior a dois anos, considerados, neste requisito, inclusive os contratos com duração inferior, mas que, mediante sua renovação, o período de dois anos for atingido ou ultrapassado.

Importante destacar que não há um prazo pré-estabelecido a partir do qual seja possível afirmar que há um contrato de longa duração. Não obstante, como dito na parte 
introdutória deste capítulo, a experiência da autoridade concorrencial pode apontar uma proxy razoável a este respeito para delimitar um parâmetro objetivo que vise capturar aquelas operações que de fato possuem relevância concorrencial. Daí as considerações acerca de possíveis restrições à concorrência servem de fio condutor para o processo de definição de filtros para a configuração dos contratos associativos.

Nesta linha, o prazo de dois anos previsto na Resolução apresenta-se razoável para dispensar a notificação de contratos que apresentam baixo potencial ofensivo. Isso porque a experiência do Conselho tem demonstrado que, ainda que contratos inferiores a dois anos possam em tese ser considerados contratos de longa duração, tais contratos, raramente, terão o objetivo, a potencialidade ou mesmo a possibilidade de estabelecer uma estrutura econômica distinta daquela pré-existente e, portanto, capaz de alterar as relações de concorrência do mercado.

Tal parâmetro encontra-se em consonância com aquele utilizado pela Portaria Conjunta $\mathrm{n}^{\circ} 50$ de 01 de agosto de 2001, firmada entre a Secretaria de Acompanhamento Econômico do Ministério da Fazenda e a antiga Secretária de Direito do Ministério da Justiça $^{60}$, que utiliza o lapso temporal de dois anos como critério objetivo a partir do qual é possível presumir que a entrada é tempestiva, e, consequentemente, não há barreiras significativas à entrada em determinado mercado.

É importante ressaltar, contudo, que os contratos de longa duração não configuram por si sós contratos associativos. Como dito no capítulo anterior, os contratos associativos se caracterizam pela existência de um fim comum entre as partes relacionadas, a partir do qual elas reúnem esforços no desenvolvimento de uma atividade que a ambos beneficia. Com efeito, é necessária a conjugação de outros fatores a partir dos quais seja possível ao menos induzir a existência de um escopo em comum existente entre as partes, uma tentativa que procurou ser feita pelas disposições do $\S 1^{\circ}$, do artigo $2^{\circ}$ da Resolução.

\subsubsection{OBJETO CONTRATUAL, DEFINIÇÃO DE MERCADO RELEVANTE E MARKET SHARE}

O parágrafo primeiro, do artigo $2^{\circ}$ da Resolução dá continuidade à tentativa de qualificação e delimitação do conteúdo próprio dos contratos associativos. Neste intuito, o

\footnotetext{
${ }^{60}$ Portaria Conjunta SEAE/SDE $n^{\circ} 50$, DE $1^{\circ}$ de agosto de 2001, que estabelece o Guia para Análise Econômica de Atos De Concentração Horizontal, publicada no Diário Oficial da União n ${ }^{\circ} 158$-E, de 17/08/01, Seção 1, páginas 12 a 15.
} 
segundo critério estabelecido pelo dispositivo diz respeito à delimitação do objeto contratual, a definição do mercado relevante e do market share das partes relacionadas neste mercado.

O primeiro aspecto a ser observado neste ponto é a tentativa por parte da autoridade concorrencial brasileira de transposição de critérios de isenção já estabelecidos no direito comparado. Vê-se que os critérios que dizem respeito à delimitação de mercado relevante e market share, especialmente no que diz respeito às práticas verticais, muito se assemelham às disposições do Regulamento no 330/2010 da Comissão Europeia ${ }^{61}$.

O Regulamento estabelece isenções por categoria, a partir da presunção de que certos pactos celebrados entre empresas não são capazes de alterar as relações concorrenciais do mercado, mas que, pelo contrário, trazem eficiências econômicas. Como regra geral, estão isentos de controle prévio pela autoridade antitruste, os acordos verticais desprovidos de restrições graves à concorrência celebrados entre empresas que não detenham 30\% de market share em seus respectivos mercados relevantes. Já com respeito às relações horizontais, presumir-se-ia a existência de um contrato associativo (escopo em comum) entre as partes quando algumas delas, ou em conjunto, pudessem alcançar participação de $20 \%$ do mercado relevante afetado pelo objeto do contrato.

\footnotetext{
${ }^{61}$ Segundo os termos do Regulamento $\mathrm{n}^{\circ} 330 / 2010$ da Comissão Européia: Artigo $2^{\circ}$ Isenção 1 . Nos termos do artigo $101^{\circ}, \mathrm{n}^{\circ} 3$, do Tratado e sem prejuízo do disposto no presente regulamento, o artigo $101^{\circ}, \mathrm{n}^{\mathrm{o}} 1$, do Tratado, é declarado inaplicável aos acordos verticais. Esta isenção é aplicável na medida em que estes acordos contenham restrições verticais. 2. A isenção prevista no $\mathrm{n}^{\circ} 1$ só é aplicável aos acordos verticais concluídos entre uma associação de empresas e os seus membros, ou entre essa associação e os seus fornecedores, se todos os seus membros forem retalhistas de bens e se nenhum membro individual da associação, em conjunto com as empresas a si ligadas, tiver um volume de negócios total anual que ultrapasse 50 milhões de EUR. Os acordos verticais concluídos por essas associações estão abrangidos pelo presente regulamento, sem prejuízo da aplicação do artigo $101^{\circ}$ do Tratado a acordos horizontais concluídos pelos membros da associação ou a decisões tomadas pela associação. 3. A isenção prevista no n.o 1 é aplicável aos acordos verticais que contenham disposições relativas à atribuição ao comprador ou à utilização pelo comprador de direitos de propriedade intelectual, desde que tais disposições não constituam o principal objecto de tais acordos e estejam directamente relacionadas com a utilização, venda ou revenda dos bens ou serviços pelo comprador ou pelos seus clientes. A isenção é aplicável na condição de que, em relação aos bens e serviços contratuais, tais disposições não incluam restrições da concorrência que tenham o mesmo objecto que restrições verticais não isentas ao abrigo do presente regulamento. 4. A isenção prevista no n.o 1 não é aplicável aos acordos verticais concluídos entre empresas concorrentes. Contudo, é aplicável quando empresas concorrentes concluem um acordo vertical não recíproco e: a) $\mathrm{O}$ fornecedor é um fabricante e distribuidor de bens e o comprador é um distribuidor e não uma empresa concorrente a nível do fabrico; ou b) $\mathrm{O}$ fornecedor é um prestador de serviços em vários estádios da actividade comercial, enquanto o comprador fornece os seus bens ou serviços a nível retalhista e não é uma empresa concorrente no mesmo estádio da actividade comercial em que adquire os serviços contratuais. 5. O presente regulamento não é aplicável aos acordos verticais cuja matéria seja abrangida pelo âmbito de aplicação de qualquer outro regulamento de isenção por categoria, salvo disposição em contrário desse regulamento. Artigo $3^{\circ}$ Limiar da quota de mercado 1 . A isenção prevista no artigo $2^{\circ}$ é aplicável na condição de a quota de mercado do fornecedor não ultrapassar $30 \%$ do mercado relevante em que vende os bens ou serviços contratuais e de a quota de mercado do comprador não ultrapassar $30 \%$ do mercado relevante em que compra os bens ou serviços contratuais.
} 
A reintrodução dos critérios de participação de mercado nas análises a serem empreendidas pelo CADE deve ser vista com muito ceticismo, mesmo que tais critérios decorram de uma "importação" de melhores práticas do direito comparado. Esse entendimento se justifica porque a transposição de critérios e requisitos do direito comparado deve guardar uma consonância estrita com a realidade econômica e, principalmente, jurídica do país ${ }^{62}$.

Como já salientado nos capítulos anteriores, a Lei n. 12.529/2011 se afasta do critério consequencialista da antiga Lei e estabelece critérios mais rígidos de sujeição das operações interempresariais ao controle preventivo: a existência de um ato de concentração e o faturamento mínimo conforme definido pela Lei.

Os contratos associativos, por sua vez, se caracterizam pela existência de um escopo em comum entre as partes, e por tal razão são enquadrados como um ato de concentração, uma vez que deste fim em comum decorre necessária perda de autonomia econômica entre as partes e, consequentemente, leva à formação de uma nova unidade econômica distinta daquela pré-existente.

O critério de participação de mercado, como muito se sabe, é uma proxy a partir da qual busca-se investigar o poder de mercado detido pelas empresas e, consequentemente, os riscos potenciais à concorrência em razão da existência de posição dominante. É certo que a celebração de contratos entre concorrentes pode gerar preocupações concorrenciais, seja pelo eventual incentivo à colusão, seja por abrir a possibilidade de acesso a informações estratégicas de rivais. Não obstante, o risco concorrencial foi expressamente afastado pela nova Lei como critério único de configuração de ato de concentração. Deste modo, não importa se a operação tem riscos ou não à concorrência, desde que satisfeitos os critérios do faturamento e a configuração do ato de concentração, a operação deve ser necessariamente submetida ao controle preventivo de estruturas. Pelo contrário, se não há ato de concentração, não deve haver a notificação ainda que haja riscos concorrenciais.

Ademais, ainda que o risco concorrencial possa ser usado como ponto de partida para se traçar critérios objetivos de presunção de atos de concentração, tal metodologia deve estar restrita à manutenção da autonomia conceitual dos contratos associativos. Isso significa

\footnotetext{
${ }^{62}$ Neste sentido também foi o pronunciamento do Presidente do CADE, Vinícius de Carvalho, no julgamento dos Atos de Concentração Monsanto em 2013. Segundo o Presidente, "a definição de filtros adequados tem sido reconhecida como um dos maiores desafios para a estruturação de uma política de defesa da concorrência adequada à realidade de cada país".
} 
que o enquadramento nas hipóteses elencadas no artigo 90 da Lei n. 12.529/2011 deve ser aferido com bases em argumentos que não se limitem a fazer remissão ao potencial anticompetitivo da operação com justificativa para submissão ao controle preventivo de estruturas. Com efeito, não se afigura fácil delimitar exclusivamente com base numa análise econômica da coordenação de atividades empresariais as relações de cooperação que dão corpo a um empreendimento em comum daquelas relações comutativas de execução duradoura (Lima Pinheiro 2003, p. 62).

Como se nota no caso das relações horizontais, o critério proposto apresenta-se muito abrangente e acaba por afastar a própria autonomia conceitual de contratos associativos, uma vez que não traz elementos mínimos de definição da existência de um escopo em comum entre as partes. Isso significa que os critérios, ainda que cumulativos, de contrato por prazo de dois anos e market share de $20 \%$, não são suficientes para alcançar a delimitação própria de contratos associativos, tão pouco de ato de concentração.

Como já ressaltado inúmeras vezes, o controle preventivo é seletivo e deve estar restrito aos critérios rígidos definidos pelo legislador, no caso, a configuração de um ato de concentração e o faturamento mínimo legal. Importante considerar, no entanto, que o fato de determinada operação ser dispensável de notificação não significa que os comportamentos dos agentes econômicos envolvidos não permaneçam sujeitos ao escrutínio da autoridade concorrencial no âmbito de controle de condutas.

Ainda nesta linha, nota-se um manifesto excesso por parte da autoridade antitruste brasileira ao reintroduzir o índice de participação de mercado como critério de notificação de atos de concentração, inclusive porque a Resolução dá margem à interpretação no sentido de que o critério de market share (estabelecido pela Resolução) e faturamento (estabelecido pela Lei) devam ser cumulativos, e não alternativos, para obrigar a notificação da operação.

A Resolução cria, portanto, um novo critério que é capaz até mesmo de afastar do controle preventivo aquelas hipóteses que seriam claramente de incidência da lei. $O$ legislador, ainda que mal orientado, designadamente inovou, não fixando como critério de notificação a participação de mercado dos figurantes do ato de concentração. Logo, não pode o CADE substituí-lo fixando em resolução tal índice ${ }^{63}$ como um critério cumulativo de notificação, o qual, como visto, não traz em seu seio qualquer elemento que possa apontar a existência de um escopo em comum entre as partes.

\footnotetext{
${ }^{63}$ No mesmo sentido foi a contribuição do escritório de advocacia Pedro Dutra à Consulta Pública no 03 de 2014.
} 
Como visto no capítulo anterior, talvez uma das razões que tenha levado o legislador a utilizar a expressão "contratos associativos", é o propósito de alcançar algumas operações que, muito embora não utilizem a nomenclatura joint venture - mas sim "parceria comercial”, "aliança estratégica”, etc. - apresentam em sua essência características próprias das joint ventures: (i) a existência de um fim comum; (ii) o compartilhamento de risco entre os contratantes; (iii) a criação de uma interdependência organizativa que permita acompanhar, executar e monitorar a realização da atividade assumida pelas partes e (iv) a criação de um novo centro de controle da atividade empresarial.

Nesta linha, a Resolução acaba criando uma grande lacuna na Lei, propondo novos critérios de notificação de joint ventures, usurpando, dessa forma, a vontade do legislador, que definiu para estes casos, tão somente o critério do faturamento como requisito de notificação.

Um exemplo real desta hipótese se verifica no caso da Consulta $n^{\circ}$ 08700.006564/2014-85 apresentada ao CADE em 11.08.2014. A Castrolanda - Cooperativa Agroindustrial Ltda. apresentou a referida consulta, requerendo que o CADE se manifestasse sobre a obrigatoriedade de notificação de operações que concernem à celebração de um contrato de parceria entre cooperativas agroindustriais para a operação conjunta de uma unidade industrial, no caso, uma unidade de processamento de industrializados de carne.

Consoante os termos da Consulta, a Castrolanda, em conjunto com a Batavo Cooperativa Agroindustrial (Batavo) e a Capal Cooperativa Agroindustrial (Capal) possuem interesse em investir e participar de Unidades Estratégicas de Negócios (UENs) industriais sob o modelo no qual cada cooperativa assume o papel de líder de determinado projeto, com a integração natural das demais, de modo que a intercooperação dilua os riscos do empreendimento entre os participantes.

As cooperativas participarão por meio de investimentos, despesas préoperacionais, aporte de capital, fluxo de caixa e resultados, conforme suas respectivas participações: (i) Castrolanda: 55\%; (ii) Batavo: 25\% e (iii) Capal: 20\%. Dentre as disposições contratuais previstas no Contrato de Parceria, será estabelecida uma gestão operacional própria para o empreendimento (i.e., diretoria, comitê da UIC e gerente da indústria), políticas de destinação de resultados, uso de marcas desenvolvidas em conjunto pelas cooperativas e, dentre outras questões, uma relação de solidariedade passiva no que tange à responsabilidade por vínculos trabalhistas. O Contrato ainda prevê duração mínima de 
10 anos conforme dispõe o considerando "i" do referido acordo. Por fim, as cooperativas apresentaram seus respectivos faturamentos relativos ao ano de 2013: (i) Castrolanda obteve R\$ 1,7 bilhões; (ii) Batavo, R \$ 1,42 bilhões; e (iii) Capal, R \$ 770 milhões.

Trata-se, claramente, da configuração de um ato de concentração pela formação uma típica joint venture, que ao se utilizar de outros termos contratuais, leva o administrado a acreditar que referido contrato estaria sujeito aos requisitos da nova Resolução, e não da Lei, a qual requer tão somente o critério do faturamento para ensejar a notificação. A Resolução abre, portanto, uma grande lacuna na lei ao criar novos critérios de notificação de joint ventures, usurpando, dessa forma, a vontade do legislador, que definiu para estes casos, tão somente o critério do faturamento como requisito de notificação.

Ademais, ainda que não se entenda que tais critérios usurpam a competência legislativa, são critérios que igualmente estão longe de estabelecer segurança e objetividade aos requisitos de notificação dos contratos associativos.

Como muito se sabe, um dos maiores riscos que se verifica nas mutações de metodologia jurídico-econômica de análise do quadro do ordenamento da concorrência tradicionalmente marcado por processos de análise econômica - corresponde a uma excessiva utilização de modelos econômicos, recebidos de forma abstrata e sem o necessário crivo de verificação empírica através de estudos de mercado, ou mesmo através de situações já analisadas in concreto pela autoridade. Na práxis brasileira, tal característica é ainda mais relevante, a uma, porque o corpo técnico do órgão antitruste é limitado e pouco ou nenhum estudo tem sido empreendido para estudar e tecer características estruturais sobre determinados mercados relevantes; a duas, porque a jurisprudência do CADE no que tange aos critérios de definição do mercado relevante não é sistematizada, de modo que tal definição é feita sempre a partir de critérios subjetivos de cada julgador.

Outra característica que torna a imprecisão dos critérios de mercado relevante e, principalmente, de market share, mais acentuada, é a inevitável limitação informacional existente nas investigações antitruste (Pitofsky, 1979, 12). Vários dos dados de mercado que compõem o substrato básico da análise antitruste muitas vezes não estão disponíveis ou são de difícil identificação. Além disso, muitas dessas informações relevantes para a aplicação do direito concorrencial estão geralmente em posse das próprias empresas, o que dificulta, além do acesso, também aferir a veracidade desses dados. 
Sabe-se que significativa parte do processo de análise antitruste é feita a partir de ferramentas cuja aplicação ao caso concreto requer uma série de estimativas econômicas, cujos resultados são incertos ou podem variar sensivelmente conforme as premissas e métodos utilizados. Exemplo claro disso é a definição de mercado relevante, e, a partir dela, de participação de mercado, instrumental utilizado para aferir a possibilidade de exercício de poder de mercado das empresas investigadas. Esse exercício analítico aplicado aos casos concretos é geralmente cercado por alta dose de incerteza (Bergh 2002, p. 47). Com efeito, diante da inconsistência e imprecisão dos tradicionais métodos de aferição do mercado relevante, doutrinadores como Kaplow questionam a necessidade de realização desse exercício para a aplicação da lei antitruste (Kaplow, 2010).

É inegável que os modelos econômicos e as ferramentas de análise econométrica são essenciais para o desenvolvimento e aprimoramento do direito antitruste, na medida em que fornecem fundamentos para a compreensão do aparato empírico relacionado às condutas que são submetidas às autoridades de defesa da concorrência (Gerard 2012, p.2). Por outro lado, também é claro que a aplicação da lei antitruste não pode ficar condicionada a tais métodos em razão das várias limitações e fragilidades inerentes ao uso dessas ferramentas. Isso porque longe de ser uma metodologia infalível e absoluta, é uma mera ferramenta útil, mas não necessariamente imprescindível para a análise, como vem decidindo o CADE recentemente ${ }^{64}$.

A intensificação dos elementos de análise econômica nos processos de concretização jurídica das normas concorrenciais e a correlativa busca de índices gerais de apreciação acabam conferindo certo relativismo e incerteza a esse tipo de análise, despertando críticas por inúmeros doutrinadores (Shapiro 1996), (Weller 1999), (Werden e Froeb 1994). Deste modo, as críticas normalmente são direcionadas essencialmente às técnicas de definição de mercado relevante e à utilização de modelos econométricos de análise de poder de mercado.

Referidos doutrinadores preconizam a possibilidade de identificar diretamente os principais efeitos desse tipo de situação sobre a concorrência. Essa orientação, que sustenta a possibilidade de identificar diretamente os efeitos das transações comerciais sobre o processo de concorrência dispensando parâmetros econométricos na investigação, apresentou um significativo desenvolvimento no contexto norte-americano (Silva Morais 2006, p. 115). Há

\footnotetext{
${ }^{64}$ Citam-se, como exemplos, os Processos Administrativos no s 08012.004472/2000-12 e 08012.004039/2001-68.
} 
autores que defendem, inclusive, a formulação de parâmetros a partir de uma análise multidimensional de elementos econômicos relevantes para a concorrência que dispensariam processos analíticos sequenciais que tomam como ponto de partida a definição do mercado relevante (Weller 1999).

Essa tentativa de ruptura metodológica em relação a certos processos de construção jurídica se justifica em razão da possibilidade das distorções que podem gerar, em especial no momento ao qual se destina a Resolução CADE nº 10 de 2014. Se a ferramenta já apresenta controvérsias na análise de mérito, no momento da notificação ela está ainda mais longe de conferir transparência e coerência ao discurso de fundamentação da autoridade. Isso demonstra que a aferição do market share além de não ser uma ferramenta objetiva, não é propriamente um fator adequado para verificar as hipóteses de notificação, isso porque se trata de uma ferramenta utilizada para auferir o poder de mercado, que muitas vezes demanda um esforço de instrução por parte da autoridade, além de poder ser auferido por outras inúmeras formas que não propriamente essa.

Um exemplo dos limites normalmente enfrentados pelas ferramentas de definição de mercado relevante e market share se traduzem no recente julgamento dos casos Monsanto julgados em 2014 pelo CADE. A análise mais detida das informações prestadas nos autos, utilizadas para fundamentar o poder de mercado da Monsanto, poderia inclusive afastar a sua submissão ao controle preventivo, uma vez que o critério de market share sequer alcançaria os patamares estabelecidos na Resolução nº 10/2014.

Vê-se que a análise empreendida pelo Conselho baseou-se fundamentalmente em outros critérios qualitativos para fundamentar o poder de mercado da Monsanto que não propriamente o market share detido por ela. Segundo o voto-vista do Conselheiro Eduardo Pontual, a estrutura do mercado envolvido na operação era composta pelos seguintes níveis de cadeia produtiva:

a. Desenvolvimento da Tecnologia Transgênica, do qual a Monsanto faz parte, é o nível em que se objetiva a criação de um evento, o que inclui testes e aprovações regulamentares. Há fortes investimentos em P\&D, além de demandar longo tempo até a obtenção da patente; 
b. Desenvolvimento do Germoplasma, etapa na qual empresas de melhoramento genético, chamadas Obtentoras Vegetais (Obtentoras) ${ }^{65}$, desenvolvem diferentes variedades de soja (sementes matrizes). Essas empresas são proprietárias de bancos de germoplasma, que consistem em uma base física que reúne e conserva o material genético hereditário de uma espécie com o objetivo de garantir sua sobrevivência para uso das futuras gerações, o que também demanda altos investimentos em pessoas especializadas, infraestrutura de pesquisa e tempo. Em suma, são os proprietários da "genética" (semente), em que podem ser introduzidas tecnologias como a da Monsanto (a rigor, as sementes funcionam como um veículo para a referida tecnologia). Vale destacar que há dezenas de variedades de soja, cada qual com características genéticas próprias. Nesse elo, atua a Monsoy, da Monsanto, bem como empresas Requerentes licenciadas, quais sejam, Coodetec, Don Mario, Syngenta e Nidera, dentre outras;

c. Multiplicação de Sementes, composta pela indústria de sementes, ou seja, empresas e cooperativas que produzem esse produto, de acordo com a Lei n. 10.711/2003. A partir das sementes matrizes, os multiplicadores fazem a produção e comercialização em larga escala;

d. Distribuição e Comercialização, composta por empresas e Cooperativas que distribuem, comercializam e prestam assistência técnica aos agricultores que adquirem tais sementes;

e. Agricultor, que adquire a soja com tecnologia transgênica ou convencional.

De acordo com os termos da Resolução ${ }^{\circ} 10$, para fins de notificação deveriam ser considerados os mercados afetados pelo objeto do contrato. Deste modo, em se tratando de um contrato de licença de patente, deveria ser considerada a participação detida pelas partes na relação vertical entre o mercado upstream de Desenvolvimento da Tecnologia Transgênica, do qual faz parte a Monsanto, e o mercado downstream Desenvolvimento do Germoplasma, do qual fazem parte as licenciadas.

\footnotetext{
${ }^{65}$ Nos termos da Lei n. 10.711/03, que dispõe obtentor é a pessoa física ou jurídica que obtiver cultivar, nova cultivar ou cultivar essencialmente derivada;
} 
Não obstante, o Conselheiro Eduardo Pontual considerou, para fins de averiguação do poder de mercado detido pelas empresas participantes na operação, apenas a estrutura de oferta de sementes matrizes de soja para plantio com base na safra 2010/2011, para o Brasil, conforme tabelas abaixo:

Tabela 1 - Estrutura de Oferta do Mercado Brasileiro de Sementes de Soja para Plantio - Safra 2010/2011

\begin{tabular}{|c|c|}
\hline EMPRESA & PARTICIPAÇÃO DE MERCADO \\
\hline Monsoy (Monsanto)* & $21,2 \%$ \\
\hline Brasmax (Don Mario) $*$ & $19,2 \%$ \\
\hline Nidera* $^{*}$ & $9,9 \%$ \\
\hline Syngenta* $^{*}$ & $9,2 \%$ \\
\hline Pioneer $^{*}$ & $9,0 \%$ \\
\hline Embrapa $^{*}$ & $8,7 \%$ \\
\hline FMT/TMG* $^{*}$ & $8,4 \%$ \\
\hline Coodetec* $^{*}$ & $5,7 \%$ \\
\hline Relmó & $3,2 \%$ \\
\hline Don Mario* & $1,2 \%$ \\
\hline IGRA & $1,1 \%$ \\
\hline FundaCEP & $1,1 \%$ \\
\hline FT* & $1,1 \%$ \\
\hline CTPA & $0,4 \%$ \\
\hline Whertec* & $0,3 \%$ \\
\hline Outros & $0,4 \%$ \\
\hline Total & $100 \%$ \\
\hline
\end{tabular}

Fonte: Kleffmann e Gabinete 06

Nota do Gabinete: * empresas licenciadas para RR1 com AC julgados pelo CADE.

- empresas licenciadas para Intacta PRO RR2 em ACs julgados pelo CADE.

Tabela 2 - Estrutura de Oferta do Mercado Brasileiro de Sementes de Soja para Plantio com base em área certificada - Safra 2010/2011

\begin{tabular}{|c|c|}
\hline EMPRESA & PARTICIPAÇÃO DE MERCADO \\
\hline Monsoy (Monsanto)* $*$ & $22,99 \%$ \\
\hline Pioneer & $7,74 \%$ \\
\hline Syngenta* ${ }^{*} \cdot$ & $7,56 \%$ \\
\hline Nidera* $\bullet$ & $10,19 \%$ \\
\hline Brasmax (Don Mario) $* *$ & $12,70 \%$ \\
\hline Coodetec** & $11,01 \%$ \\
\hline Embrapa* & $12,67 \%$ \\
\hline FMT/TMG** & $6,55 \%$ \\
\hline Outros & $8,59 \%$ \\
\hline Total & $100 \%$ \\
\hline
\end{tabular}

Fonte: Kleffmann e Gabinete 06

Nota do Gabinete: * empresas licenciadas para RR1 com AC julgados pelo CADE.

- empresas licenciadas para Intacta PRO RR2 em ACs julgados pelo CADE 
A partir desse quadro, o Conselheiro Eduardo Pontual entendeu que a Monsanto, detentora da patente da RR, era líder de mercado, diretamente através da Monsoy e possuía grande dominância através de suas licenciadas. Isso porque, considerando os contratos de licenciamento apresentados pela Monsanto até 2011, ela teria, segundo o Conselheiro, influência sobre cerca de $75 \%$ da estrutura de oferta ou até $70 \%$ da área plantada de soja no Brasil em 2010/2011.

O poder de mercado da Monsanto foi aferido, portanto, com base na capacidade de influência da Monsanto no terceiro mercado downstream da cadeia produtiva e não propriamente no market share que as empresas detinham nas atividades diretamente relacionadas ao objeto do contrato.

Diante deste cenário, o Conselho entendeu que a Monsanto detinha posição dominante, e, consequentemente, as cláusulas analisadas configurariam prejuízos à concorrência. Ao final, em 2014, o Conselho, por voto da maioria, não só conheceu da operação, como também aplicou-lhe restrição, condicionando a aprovação da operação à alteração de todas as cláusulas que possuíssem efeito potencialmente criador de barreiras a entrada, bem como aquelas que permitissem qualquer interferência da Monsanto sobre a gestão estratégica das licenciadas, inclusive sua expansão.

Não se pretende aqui, por óbvio, dizer se o voto fez ou não a análise adequada do mercado afetado pelas operações da Monsanto. Na realidade, o que se pretende com essas observações é mostrar que o critério de market share, que tem como fundamento a definição do mercado relevante, é uma ferramenta que apresenta muitas controvérsias e considerável relatividade com relação aos aspectos reais da operação, principalmente em mercados que envolvam o emprego e uso de tecnologia, já que medir essa utilidade requer um grande esforço informacional, tanto das partes relacionadas quanto da autoridade concorrencial.

Nesse sentido é, inclusive, a advertência de Ana Frazão (2015a, p. 26):

diante de mercados altamente influenciados pela tecnologia, cada vez é mais difícil fazer recortes precisos de mercados relevantes na dimensão produto, até porque deve haver a análise das relações entre os mercados de pesquisa e desenvolvimento, mercados de tecnologia e mercados finais de bens e serviços. Assim, tão importante como segmentar mercados que se baseiam na tecnologia é reagrupá-los e conectá-los sob uma perspectiva dinâmica e funcional, com base em parâmetros como interconexão, compatibilidade e interoperabilidade. 
Neste cenário, de acesso a evidências limitadas e imperfeitas, é justamente onde a autoridade antitruste encontra o seu maior desafio, que é construir regras que possam ser aplicadas objetivamente, sem se valer de informações ou ferramentas que apresentam tantas falhas, ou cuja obtenção se encontra, muitas vezes, sob poder das partes.

Isso demonstra que os critérios de market share e mercado relevante não são critérios adequados a serem adotados nesse momento da análise: de conhecimento ou não da operação, já que são ferramentas que usualmente requerem uma instrução complementar e, portanto, dizem respeito ao mérito e não ao conhecimento do ato de concentração. Esse entendimento se justifica inclusive porque, se as inúmeras críticas apontam que o instrumental econômico é muito precário para fazer prognoses seguras e afastar por completo os riscos anticoncorrenciais de concentrações que já se encontram sob análise da autoridade, esse ceticismo deve ser ainda mais sensível se o instrumental é utilizado para definir os critérios de notificação.

Deste modo, é aconselhável que os critérios de definição de mercado relevante e market share não fossem usados como critérios de notificação de operações, uma vez que precisam ser contextualizados diante de outras evidências que possam aferir o real poder dos agentes diante das particularidades do mercado, o que não caberia nesse momento de tomada da decisão.

Por fim, como já salientado anteriormente, além de não se apresentar como um critério objetivo, o requisito do market share igualmente não é suficiente para apontar a existência de uma cooperação qualificada entre as contratantes, principalmente nas hipóteses de relações horizontais, em que a Resolução não apontou qualquer critério adicional a partir do qual poderia haver a formação de um "empreendimento comum" entre as empresas. Como salienta Luis Lima Pinheiro (2003, p. 63) não basta a consideração da função econômica do negócio, somente mediante uma análise do conteúdo jurídico das relações em causa será possível delimitar claramente a cooperação interempresarial.

Deste modo, é o conteúdo contratual que poderá apontar a existência ou não de uma cooperação qualificada entre as contratantes, e não propriamente o risco concorrencial gerado por interrelações empresariais, até mesmo porque a nova Lei afastou este critério de definição do ato de concentração. 


\subsubsection{CLÁUSULA DE EXCLUSIVIDADE E COMPARTILHAMENTO DE RECEITAS E PREJUÍZOS}

Como visto no primeiro capítulo, considera-se ato de concentração, para fins de incidência do controle preventivo, inclusive para as hipóteses de concentração por cooperação, qualquer processo de crescimento externo que possa alterar as estruturas concorrenciais quando duas ou mais empresas passam a perseguir um objetivo em comum entre elas. Isso porque é a partir da existência desse fim comum que poderá considerar a existência de uma unidade econômica entre as empresas contratantes.

Ocorre que a definição proposta e defendida para atos de concentração ainda apresenta relativa abrangência. No plano teórico, o ato de concentração é perfeitamente delineável, mas no plano da realidade a sua configuração não é facilmente perceptível. A conjugação dos termos como "alteração das estruturas de mercado" para a persecução de um “objetivo comum” ainda encontram dificuldades de apreensão fática.

É preciso notar que os grupos radiais nem sempre se estruturam em forma de obrigação, ou seja, nem sempre os contratos de prestação de serviços ou de fornecimento contêm cláusulas expressas de comando. Na verdade, é da intensa dependência oriunda desses contratos que se origina o poder de comando. O controle, portanto, apesar de indiretamente baseado em um contrato, é de fato (Salomão Filho, 2013, p. 136).

A partir da experiência internacional, no que diz respeito ao plano de concretização jurídica, a práxis decisória das autoridades - tanto da Europa ${ }^{66}$, quanto dos Estados Unidos - é possível notar que as características jurídicas especiais de que se revestem as inúmeras formas de contratos associativos e as inflexões que se verificam no seu tratamento têm influenciado decisivamente algumas reformulações essenciais de determinados parâmetros jurídicos de referência do direito da concorrência e a própria metodologia jurídica deste ordenamento. Criaram-se, neste contexto, condições para a formação inicial de parâmetros de análise desta figura, os quais envolvem uma conjugação complexa de condições estruturais e comportamentais relacionadas a esses contratos.

Nesta linha, a autoridade antitruste deve ser sensível a cláusulas contratuais que, extrapolando o objeto usual de um contrato comutativo, possibilitam uma cooperação diferenciada entre as contratantes e, quando analisadas sob uma perspectiva macro, são

\footnotetext{
${ }^{66}$ Essa transformação foi exaustivamente demonstrada por Luis Domingos em sua obra a respeito do tratamento de joint ventures.
} 
capazes de criar uma verdadeira unidade empresarial com inúmeras repercussões no ambiente concorrencial.

Existe um vasto campo de problematização jurídica dos acordos desprovidos de vinculatividade, mas sabe-se que mesmo conteúdos de natureza genérica dos quais decorram mera influência de comportamento podem dar corpo a diferentes tipos de cooperação entre empresas (Silva Morais 2006, p. 174). Como dito anteriormente, as alternativas à configuração da cooperação na base de compromissos contratuais são muito variadas, podendo abarcar desde práticas concertadas ilícitas até acordos desprovidos de qualquer caráter cogente.

De qualquer modo, sobre o manto da teoria dos "efeitos práticos-jurídicos" é possível presumir vinculatividade a partir da "vontade funcional" das empresas relacionadas, no sentido de buscar extrair a extensão e o modo como se devam concretizar os específicos efeitos jurídicos que melhor traduzam o fim prático perseguido pelas partes (Lima Pinheiro 2003, p. 125), na medida em que uma certa intensidade da vontade dirigida a efeitos práticos tenderá mais facilmente a atrair consequências jurídicas. Principalmente em sede de aplicação do direito da concorrência, ensina Luis Domingos Silva Morais (2006, p. 174) que há

especificidades na apreensão jurídica de acordos relacionados com a
cooperação empresarial, visto que, em múltiplas situações, será suficiente
que exista uma vontade das partes dirigida aos aspectos econômicos
concretos que integrem o núcleo essencial do objeto do acordo, para que se
produzam consequências jurídicas de submissão desses acordos a
normativos de direito da concorrência.

Neste particular, tal como acertadamente delimitado pelo voto do Presidente do CADE, Vinícius de Carvalho, no AC Monsanto ${ }^{67}$, a caracterização dos contratos associativos ultrapassa a mera constatação de cooperação e passa por considerações mais detalhadas sobre a independência das partes contratantes a partir da análise de cláusulas contratuais que têm, presumivelmente, capacidade de resultar na formação de uma nova unidade econômica, seja pela possibilidade de ingerência nas decisões comercialmente relevantes de uma das contratantes, pela condução mútua ou pelo compartilhamento conjunto dos riscos do empreendimento.

Sendo assim, o uso de presunções no direito antitruste assume relevância, porque, ainda que não estabeleçam de modo exato as hipóteses de incidência da legislação, oferecem

\footnotetext{
${ }^{67}$ Vide nota 31.
} 
parâmetros objetivos que, a partir da experiência da autoridade, já tenham demonstrado que aquelas circunstâncias tendem a configurar, no caso dos atos de concentração, a existência de um objetivo comum entre as empresas relacionadas que podem causar alterações nas estruturas de mercado.

Se não há como definir de forma exata essas hipóteses, é relevante o papel da autoridade em estabelecer pelo menos filtros claros e objetivos a partir dos quais seja provável a ocorrência de uma concentração empresarial, identificada pela (i) a existência de um fim comum; (ii) o compartilhamento de risco entre os contratantes; (iii) a criação de uma interdependência organizativa que permita acompanhar, executar e monitorar a realização da atividade assumida pelas partes, (iv) a criação de um novo centro de controle da atividade empresarial, ou (iii) o exercício de poder de comando ou gestão, entendendo-se este último não apenas como o controle societário, mas como qualquer forma de influência decisiva na condução dos negócios empresariais de qualquer das empresas relacionadas.

A Resolução $n^{\circ}$ 10/2014 identificou nas seguintes cláusulas contratuais a possibilidade de existência de um escopo comum entre as partes: (i) cláusulas de exclusividade; ou (ii) cláusulas que estabeleçam o compartilhamento de receitas ou prejuízos entre as partes.

A exclusividade consiste em uma obrigação assumida por uma das partes de contratar exclusivamente com a outra no tocante a determinado bem ou serviço. A obrigação pode ser assumida por um ou por ambos os contratantes.

Evidentemente a cláusula de exclusividade, por si só, não implica a existência de um ato de concentração, tampouco a existência de um objetivo comum perseguido pelas partes. Muitas vezes, a cláusula de exclusividade é utilizada como uma mera restrição vertical, sequer necessária à consecução do objeto contratual.

Não obstante, é possível presumir a partir dessa cláusula a possibilidade de formação de uma concentração empresarial a depender do tempo que persista entre as partes. Ou ainda, trata-se de um critério objetivo identificado pela autoridade a partir de sua experiência de que tais disposições podem levar a situações de controle externo, objetivamente apreensível pelas cláusulas contratuais.

Como afirma Forgione, a cláusula de exclusividade potencializa a influência que uma parte contratante exerce sobre a outra (Forgioni 2008, p. 253). Igualmente, encontra-se 
associada a uma "prisão econômica", em que os efeitos afrontam diretamente o individualismo de cada uma das contratantes.

A exclusividade igualmente altera a estrutura de concorrência do mercado, tornando-o mais concentrado uma vez que os "remanescentes" enfrentam uma concorrência menor com a saída daquele verticalmente integrado (Forgioni 2008, p. 257). Deste modo, a exclusividade tem efeito direto sobre a estrutura de mercado, principalmente porque resulta no aumento de poder unilateral da empresa que impõe a restrição, por meio do fechamento do mercado ou do aumento de barreiras à entrada no segmento downstream, atuando, portanto, sobre a independência econômica das partes.

Ainda que a cláusula de exclusividade seja um critério mais relacionado aos riscos concorrenciais de uma determinada relação interempresarial, é possível, inclusive, presumir a existência de um escopo em comum entre as partes a partir de disposições contratuais nesse sentido. Isso porque, como explica Paula Forgioni (2008), a exclusividade implica ganhos (ou possibilidade de ganhos) para ambos os fornecedor e o distribuidor, pois, se assim não fosse, não a teriam contratado.

Nesta mesma linha, as lições de Hart e Tirote (1990, p. 206) são bastante elucidativas no sentido de que a cláusula de exclusividade pode implicar a existência de uma unidade empresarial entre os entes contratantes, porque pressupõe direitos residuais de controle sobre ativos concorrencialmente sensíveis e apresenta efeitos semelhantes no que diz respeito ao compartilhamento de receitas entre as contratantes:

Supomos que as empresas a montante e a jusante não sabem ex ante qual o tipo de bem intermediário será o mais adequado para o comércio e que o grande número de tipos potenciais aumenta os custos em firmar contratos contigenciais a prazo. Como resultado, a única maneira de influenciar o comportamento ex post é através da atribuição de direitos residuais de controle sobre os ativos. Além disso, tomamos o ponto de vista de que a mudança de direitos de controle residual que ocorre por meio da integração permite repartição dos lucros entre unidades upstream e downstream. Como consequência, todos os conflitos de interesses sobre os preços e as políticas comerciais são removidos. A este respeito, a integração vertical não difere formalmente de um esquema de divisão de lucros entre os contratantes independentes. No entanto, a participação nos lucros pode ser difícil de implementar, na ausência de integração, porque as unidades independentes podem desviar dinheiro e deturpar os lucros. Em contraste, o proprietário de uma unidade subordinada, porque ele ou ela tem direitos residuais de controle sobre os ativos, pode ser capaz de impedir o desvio e forçar a participação nos lucros. ${ }^{68}$

\footnotetext{
${ }^{68}$ Tradução livre do seguinte trecho da obra: "We assume that the upstream and downstream firms do not know ex ante which type of intermediate good will be the appropriate one to trade and that the large number of
} 
Deste modo, a cláusula de exclusividade é uma modalidade de integração vertical (Hovenkamp 2014, p. 1) normalmente associada ao comportamento unilateral do agente, que, no entanto, provoca efeitos no mercado semelhantes ao ato de concentração, principalmente no que diz respeito à agregação de poder econômico por parte da empresa que impõe a restrição.

São também exemplos de cláusulas cujos efeitos são equivalentes a cláusulas de exclusividade as cláusulas que i) contenham restrições referentes ao volume, estrutura de produção, ii) proíbam o uso de tecnologias competidoras, iii) estabeleçam opção de compra total ou parcial em favor do provedor de tecnologia, iv) obriguem ao comprador de tecnologia transferir ao supridor os aperfeiçoamentos ou melhoramentos que se obtenham como o uso da dita tecnologia, v) obriguem a pagar "royalties" a titulares de patentes por patentes não utilizadas (Barbosa 2005, p. 168).

Sendo assim, poderão ser considerados contratos associativos aqueles contratos que estabeleçam cláusulas que levam a efeitos semelhantes às concentrações econômicas, no que diz respeito à agregação de poder econômico por parte das contratantes, tais como: características contratuais que envolvam exclusividade no uso da capacidade produtiva da empresa, ou envolvam restrições ou incentivos que interfiram nas decisões comerciais de alguma das contratantes, principalmente escolhas relacionadas à contratação de produtos ou serviços concorrentes ${ }^{69}$.

Outro aspecto apontado na Resolução como demonstrativo da existência de um fim em comum entre as partes contratantes encontra apoio na identificação da assunção comum do risco entre elas, que está intrinsecamente associada às cláusulas contratuais que estabelecem ou preveem a possibilidade de compartilhamento de receitas e prejuízos relacionados à atividade.

potential types makes it too costly to write contingent forward contracts. As a result, the only way to influence ex post behavior is through the allocation of residual rights of control over assets. Moreover, we take the point of view that the shift in residual control rights that ocurs under integration permits profit sharing between upstream and downstream units. As a consequence, all conflicts of interests about prices and trading policies are removed. In this respect, vertical integration does not deffer formally from a profit-sharing scheme between independet contractors. Profit sharing may be difficult to implement in the absence of integration, however, because independent units can divert money and misrepresent profits. In contrast, the owner of a subordinate unit, because he or she has residual rights of control over the unit's assets, may be able to prevent diversion and enforce profit sharing".

${ }^{69}$ Neste mesmo sentido foi o voto-vista do Conselheiro Eduardo Pontual no AC Monsanto julgado em 2013. 
A previsão contratual de compartilhamento de receitas ou prejuízos, tal como a cláusula de exclusividade, pode não implicar por si a existência de um empreendimento em comum entre as empresas relacionadas.

A exemplo desta hipótese, Luis Lima Pinheiro (2003, p. 213) cita os contratos parciários em que as partes estabelecem uma contrapartida de atribuição patrimonial consistente num crédito sobre os resultados futuros da atividade econômica ou de uma operação econômica concreta. Contratos parciários seriam, por exemplo, contratos de financiamento de Pesquisa e Desenvolvimento, em que uma das partes financia a atividade da outra e adquire, em contrapartida, sem constituir qualquer empresa ou associação, o direito de participar com determinada quota-parte dos produtos ou lucros durante certo tempo. Também nesta linha, Luis Lima Pinheiro (2003, p. 214) afirma que são frequentes contratos de licença, concessão ou franquia que estabelecem como contrapartida o direito de participar nos resultados (royalties).

Seria, portanto, uma modalidade contratual transitória entre os contratos comutativos e os contratos associativos, em que ocorre assunção parcial do risco econômico, uma vez que a contrapartida da parte que faz a contribuição fica dependente da obtenção de lucro pela outra parte (Lima Pinheiro 2003, p. 217). Ademais, na medida em que as partes limitam a participação associada às perdas estariam limitando a assunção comum dos riscos, descaracterizando, portanto, a existência de um escopo comum entre elas (Lima Pinheiro 2003, p. 229).

Por outro lado, não há como negar que a existência de cláusulas contratuais que estabeleçam compartilhamento de lucros ou prejuízos constituem fortes indícios da existência de um fim comum entre as partes relacionadas. Isso porque, qualquer previsão de participação nos benefícios constitui um resultado funcional para a realização de uma atividade programada, configurando, assim, um meio com respeito a um fim. Isso significa que a participação no resultado assume importância enquanto constitui instrumento para o exercício da atividade relacionada ao fim comum. A tal respeito, a característica do fenômeno associativo consiste, assim, na expressão de uma ação com valor metaindividual, em que é subentendido um interesse pertencente a uma coletividade e cuja realização constitui o fim da ação conjunta.

Nesta linha, é de se esperar que da existência de um fim comum decorra necessariamente a participação de ambas as partes nos resultados obtidos. Não existindo 
propriamente uma repartição de lucros, verifica-se uma especificidade na obtenção de vantagens patrimoniais nos contratos associativos, que resultam da realização de sucessivos atos de troca entre concedente e concessionário e entre este e terceiros (Lima Pinheiro 2003, p. 185). A mera possibilidade de participação conjunta nos benefícios da atividade de uma das contratantes com terceiros sugere, portanto, a existência de um escopo comum entre os contratantes.

Nesta linha foi inclusive a decisão do CADE no julgamento do Caso Monsanto em 2013. O voto vencedor do Conselheiro Eduardo Pontual procurou destacar elementos da relação contratual que poderiam afetar de forma significativa a independência econômica entre as partes, caracterizando assim alteração estrutural pertinente à definição de ato de concentração. Dentre elas destaca-se a forma de incentivos desenhados pela Monsanto que possibilitava sua influência em decisões estratégicas da empresa contratante, principalmente com relação à tecnologia concorrente.

Deste modo, como bem salientado pelo Presidente do CADE Vinícius de Carvalho no julgamento do AC Monsanto, a caracterização do contrato associativo como ato de concentração ultrapassa a mera constatação de cooperação entre as partes, mas passa pela consideração sobre a independência delas a partir da análise dos possíveis efeitos que determinadas cláusulas do contrato tem na capacidade de ingerência de uma parte nas decisões contratualmente relevantes de outra.

Como bem explica Luis Domingos Silva Morais (2006, p. 173), as alternativas à configuração da cooperação na base de compromissos contratuais são muito variadas. Observa ele que a cooperação obrigacional pode abarcar desde práticas concertadas que não atendem aos requisitos de validade do negócio jurídico até acordos desprovidos no todo ou em parte de vinculatividade jurídica, a partir de conteúdos de natureza genérica dos quais decorram mera influência de comportamento, sem verdadeiro caráter cogente, mas que, no entanto, são capazes de provocar verdadeira integração econômica, uma vez que possibilitam a agregação de poder empresarial de direção da atividade de uma empresa sobre a outra, ou conjuntamente por todas as empresas relacionadas.

Por fim, é preciso ter consciência de que é impossível estabelecer critérios objetivos que esgotem todas as possibilidades de identificação da existência de um escopo em comum entre as partes. É preciso acumular experiência na análise de casos limítrofes de modo que os problemas enfrentados na realidade sejam devidamente abarcados pelo novo regime. 
É preciso compreender, desta forma que, longe de oferecer parâmetros fixos para a análise ou de ser instrumento hábil a propiciar prognoses revestidas de caráter absoluto, a Resolução apenas tem por finalidade conferir à análise concorrencial transparência e critérios mínimos de objetividade. O papel dos filtros, a que vem se referindo ao longo do trabalho, não é outro senão o de captar, de forma indireta e mais objetiva possível, as transações comerciais que se enquadram nos contratos associativos e, consequentemente, afetam de forma significativa a independência entre as partes, caracterizando assim uma alteração estrutural pertinente à definição de atos de concentração nos termos da Lei n. 12.529/2011.

Neste aspecto, ainda que não tenha esgotado as possibilidades a partir das quais seja possível identificar a existência de um fim comum, o que será feito futuramente com acúmulo de experiência, a Resolução foi acertada ao prever, dentre estas possibilidades, as hipóteses da cláusula de exclusividade e do compartilhamento de receitas e prejuízos. Tais hipóteses, se não significam por si sós a existência de um fim comum, no mínimo, são indicativas muito próximas neste sentido.

Todavia, em razão dos critérios já explorados no item anterior - de definição de mercado relevante e market share -, a atual Resolução do CADE ainda carrega a insegurança jurídica tão presente no sistema anterior e, sendo assim, está longe de alcançar transparência e objetividade no que diz respeito à definição dos critérios de legalidade para notificação de contratos associativos ao controle de estruturas brasileiro. 


\section{CONCLUSÃO}

A fragmentação da empresa realçou a importância de inúmeros contratos que, como é o caso dos contratos associativos, mostram novas formas de cooperação e organização empresarial que constituem efetivamente uma "terceira-via" entre a empresa e o mercado, posto que não se baseiam na constituição de uma pessoa jurídica nem na aquisição de participações societárias e formação de grupos societários, mas tão somente em vínculos contratuais.

A dissertação buscou abordar as principais características e funções jurídicas e econômicas dos contratos associativos, buscando identificar a sua relevância para o direito da concorrência. Procurou também demonstrar que há uma necessidade de ampliar a reflexão jurídica acerca deste fenômeno empresarial, de suas funções, de seus propósitos e em que medida isso reflete na incidência do controle preventivo do CADE.

Como se viu anteriormente, foi acertada a abertura conceitual da lei concorrencial proposta pelo legislador para que a defesa da concorrência pudesse acompanhar as naturais transformações das formas de organização empresarial impostas pelo mercado. Não obstante, em se tratando de controle preventivo, é importante que a autoridade antitruste utilize do amplo poder decisório para estabelecer critérios diferenciadores, uma vez que ainda restam inúmeras controvérsias acerca da sujeição de contratos associativos ao controle de estruturas concorrenciais.

Inconsistência e incoerência são termos críticos normalmente empregados para caracterizar a jurisprudência e a política regulatória em matéria de antitruste, e não tem sido diferente no que toca aos critérios estabelecidos pelo CADE de notificação dos contratos associativos ao controle preventivo exercido por ele. É preciso ter em mente que o aumento da complexidade da análise estrutural, ensejada pela modalidade dos contratos associativos, precisa ser adequadamente controlado por meio de metodologias e critérios que assegurem transparência e consistência na atuação das autoridades concorrenciais.

Nesta linha, é preciso, ao interpretar a Lei, dar continuidade ao trabalho de construção de filtros iniciado pelo legislador, o que deve ser feito tendo em vista a tentativa de encontrar um equilíbrio entre a necessidade de estabelecer critérios que (i) alcancem o tipo certo de transações, e.g. aquelas que levam a alterações estruturais mais duradouras no mercado e que poderiam pôr em causa os objetivos da política concorrencial; (ii) evitem capturar transações que normalmente não acarretam nenhum risco à concorrência ou que 
sejam mais adequadamente controladas por outros instrumentos do qual dispõe o regime do direito concorrencial (e.g., controle de condutas); e (iii) definam, o máximo possível, testes de análise que sejam transparentes, objetivos e claros, para determinar aquelas transações que estão sujeitas à fiscalização prévia da autoridade.

Isso significa que o controle de estruturas no que toca aos contratos associativos deve passar, mesmo após a edição da Resolução n. 10/2014, por um processo de redefinição, procurando superar as limitações das análises de mercado relevante e market share - sem obviamente ignorá-las - considerando que, para o momento de tomada de decisão que ora se discute, da notificação das operações, elas não se apresentam como a melhor ferramenta.

É inegável que os modelos econômicos e as ferramentas de análise econométrica são essenciais para o desenvolvimento e aprimoramento do direito antitruste, na medida em que fornecem fundamentos para a compreensão do aparato empírico relacionado às condutas que são submetidas às autoridades de defesa da concorrência (Gerard 2012, p.2). Por outro lado, também é claro que a aplicação da lei antitruste não pode ficar condicionada a tais métodos em razão das várias limitações e fragilidades inerentes ao uso dessas ferramentas, uma vez que apresentam alta dose de incerteza (Bergh 2002, p. 47).

Dito isso, dada a imprecisão e incertezas normalmente enfrentadas na definição das relações contratuais que devem ou não ser submetidos ao controle, é natural que a preocupação com a minimização de erros desempenhe um papel central no desenvolvimento do direito concorrencial (Kaplow e Shapiro 2007, 131). Por outro lado, importante também destacar a necessidade de construção de critérios de análise passíveis de implementação prática por parte da autoridade competente, consideradas suas várias limitações (Lowe 2008, p. 1). A construção de regras administráveis, isto é, passíveis de implementação pela autoridade competente dentro dos limites da sua capacidade, é fundamental para o direito antitruste (Hovenkamp 2010, p. 19).

Sabe-se que a complexidade do fenômeno que se busca identificar é impressionante: contratos associativos podem se apresentar nas mais variadas e nos mais diferentes contextos de mercado, muitas vezes indistinguíveis de atos ordinários realizados por empresas no curso normal de seus negócios. É inegável a existência de limites para a incorporação da riqueza de especificidades dos contratos associativos.

Não obstante, há que se procurar a melhor formatação de um processo investigativo que seja racionalmente direcionado ao momento de tomada de decisão, de modo 
que permita a intervenção adequada da autoridade para preservar as condições de concorrência no mercado e, igualmente, garantir um ambiente normativo que assegure um mínimo de previsibilidade para a atuação dos agentes econômicos, o que, todavia, não foi alcançado com a edição da Resolução CADE n. 10/2014.

Deste modo, em se tratando do momento do conhecimento das operações que devam ser submetidas ao controle preventivo, é importante que os critérios de notificação sejam traçados a partir de circunstâncias que podem ser determinadas objetivamente e, igualmente, que possam ser auferidas previamente tanto pela autoridade antitruste quanto pelo próprio administrado, dentro do limite da capacidade cognitiva de cada um.

Ademais, é preciso ter em mente que a definição de filtros adequados deve, também, resguardar o conteúdo próprio dos contratos associativos, de modo que a sua natureza não seja prejudicada por critérios demasiadamente amplos que, igualmente, afastam a vontade do legislador a respeito dos requisitos estabelecidos na nova Lei.

Por todas essas considerações, o trabalho encerra procurando acenar algumas possibilidades de adaptação da atual Resolução do CADE a respeito da notificação dos contratos associativos. $\mathrm{O}$ trabalho propõe desta forma, a seguinte redação:

Art. $1^{\circ}$ Esta Resolução disciplina as hipóteses de notificação da celebração de contrato associativo, de que trata o inciso IV do artigo 90 da Lei 12.529, de 2011.

Art. $2^{\circ}$ Respeitados os critérios objetivos estabelecidos no artigo 88 da Lei n. 12.529, de 2011, e para fins do disposto nesta lei, consideram-se associativos quaisquer contratos com duração superior a 2 (dois) anos em que houver cooperação horizontal ou vertical e compartilhamento de risco que acarretem, entre as partes contratantes, relação de interdependência.

$\S 1^{\circ}$ Para fins do disposto no caput deste artigo, considera-se que há cooperação horizontal ou vertical e compartilhamento de risco que acarretam relação de interdependência nos contratos em que as partes contratantes estiverem verticalmente ou horizontalmente relacionadas no objeto do contrato, desde que preenchida pelo menos uma das seguintes condições:

a) o contrato estabeleça o compartilhamento de receitas ou prejuízos entre as partes;

b) do contrato decorra relação de exclusividade; 
c) do contrato decorra cláusulas, até mesmo desprovida de vinculatividade, que permitam a ingerência de uma parte em decisões estratégicas da outra, em especial, que dizem respeito a tratativas desta última com concorrentes.

$\S 2^{\circ}$ Para fins do $\S 1^{\circ}$ deste artigo, consideram-se partes contratantes as entidades diretamente envolvidas no negócio jurídico sendo notificado e os respectivos grupos econômicos, conforme definição do artigo $4^{\circ}$ da Resolução $n^{\circ} 2$, de 29 de maio de 2012.

$\S 3^{\circ}$ Os contratos com duração inferior a dois anos devem ser notificados nos termos desta Resolução quando, mediante sua renovação, o período de 2 (dois) anos for atingido ou ultrapassado.

Art. $3^{\circ}$ Esta Resolução entra em vigor após decorridos 60 (sessenta) dias de sua publicação oficial.

A proposta apresentada mantém o prazo contratual previsto na atual resolução. Os contratos associativos estabelecem uma relação de cooperação estável e duradoura entre as partes contratantes, que se apresenta como primeiro pressuposto para a existência de um fim comum entre elas. Ademais, no quarto capítulo, ao abordar este aspecto, concluiu-se que o prazo de dois anos previsto na Resolução n.10/2014 apresenta-se razoável para dispensar a notificação de contratos que apresentam baixo potencial ofensivo. A experiência do Conselho tem demonstrado que, ainda que contratos inferiores a dois anos possam, em tese, ser considerados contratos de longa duração, tais contratos, raramente, terão o objetivo, a potencialidade ou mesmo a possibilidade de estabelecer uma estrutura econômica distinta daquela pré-existente e, portanto, capaz de alterar as relações de concorrência do mercado.

Quanto às alterações, a proposta sugere, primeiramente, afastar os requisitos de market share, mantendo somente o critério do faturamento já previsto na Lei. Como já explicado no quarto capítulo, tal requisito apresenta falhas e não é adequado ao momento da notificação dos contratos associativos, porque: (i) se considerados cumulativos com o critério de faturamento, acaba usurpando a vontade do legislador com relação às operações que devem ser submetidas ao controle; (ii) não é elemento suficiente para caracterizar contratos horizontais como contratos associativos; (iii) a ferramenta é controversa e apresenta falhas; (iv) está longe de estabelecer segurança e objetividade aos requisitos de notificação dos contratos associativos; (v) para sua implementação, requer uma capacidade cognitiva, de acesso a dados do mercado, que muitas vezes até a própria empresa não a detém. 
A segunda alteração proposta é estender as condições anteriormente aplicadas aos contratos verticais, também aos contratos horizontais. Neste aspecto, é preciso considerar que a natureza dos contratos associativos é única, não apresenta distinção entre as relações verticais e horizontais. No terceiro capítulo, ao explorar as características e o conceito dos contratos associativos, verificou-se que estes caracterizam-se pela existência de um fim comum entre as partes relacionadas, a partir do qual elas reúnem esforços no desenvolvimento de uma atividade que a ambas beneficia. Com efeito, é necessária a conjugação de outros fatores a partir dos quais seja possível ao menos induzir a existência de um escopo em comum existente entre as partes, uma característica que deve estar presente tanto nas relações verticais quanto nas horizontais.

Por fim, a proposta procura ampliar o rol de hipóteses a partir do qual seja possível induzir a existência de um escopo comum entre as contratantes. O rol é ampliado com base na experiência recente do Conselho a respeito dos contratos associativos, em especial os ACs Monsanto julgados em 2013 pelo CADE.

O voto do Conselheiro Eduardo Pontual logrou apontar alguns elementos dos contratos da Monsanto que afetavam de forma significativa a independência econômica entre as partes, caracterizando assim uma alteração estrutural pertinente ao conceito de ato de concentração. Isto é, contratos que não se ajustando às hipóteses clássicas de concentração, tem levado a efeitos semelhantes no mercado em razão da existência de um fim em comum entre as contratantes capaz de levar à agregação de poder empresarial e, consequentemente, ao aumento de poder de comando ou gestão de uma contratante sobre a outra.

Dentre os elementos que foram destacados no voto e que merecem ser considerados na resolução diz respeito à cláusulas contratuais de incentivo que abrem margem para que uma contratante influencie em decisões estratégicas da outra para além do objeto do contrato, principalmente no que diz respeito a tratativas com concorrentes.

Deste modo, a proposta procura elencar filtros que possam captar de forma indireta e mais objetiva possível as operações que apresentam características próprias dos contratos associativos e que, consequentemente, devem ser submetidas ao controle de estruturas concorrencial. É certo que os filtros aqui proposto estão igualmente sujeitos a muita discussão, no entanto, entende-se que os critérios são identificáveis de forma mais simples, exigindo menos esforço cognitivo tanto das contratantes quanto da autoridade antitruste, do que a atual resolução. 


\section{REFERÊNCIAS}

ANDERSON, Patrick, Theodore Bolema, e Ilhan Geckil. 2007. "Damages in Antitrust Cases". AEG Working Paper 2007-2. East Lansing, Chicago: Anderson Economic Group. http://www.andersoneconomicgroup.com/Portals/0/upload/Doc2066.pdf.

BELOHLÁVEK, Alexander. 2008. "Law governing joint venture status and joint venture agreements. International Joint Ventures". The comparative law yearbook of international business, n. 30, 2008, pp. 507-541.

BAKER, Jonathan. 2002. "A Preface to post-Chicago Antitrust". In Post-Chicago Developments in Antitrust Law, 60-75. Edward Elgar Publishing.

- 2012. "Exclusion as a Core Competition Concern". SSRN Scholarly Paper ID 2001579. Rochester, NY: Social Science Research Network. http://papers.ssrn.com/abstract=2001579.

BAKER, Jonathan, e TIMOTHY Bresnahan. 2006. "Economic Evidence in Antitrust: Defining Markets and Measuring Market Power". SSRN Scholarly Paper ID 931225. Stanford Law and Economics Olin Working Paper No. 328. Rochester, NY: Social Science Research Network. http://papers.ssrn.com/abstract=931225.

BARBOSA, Denis Borges. 2005. A criação de um ambiente competitivo no campo da propriedade intelectual - o caso sul americano. International Centre for Trade and Sustainable Development. Suiça.

BERGH, Roger Van Den. 2002. "The Difficult Reception of Economic Analysis in European Competition Law”. In Post-Chicago Developments in Antitrust Law, 34-59. Edward Elgar Publishing.

BITTAR, Carlos Alberto. 2010. Contratos comerciais. Rio de Janeiro: Forense.

BLACKWELL, Richard B. 1972. Section 7 of the Clayton Act: Its Application to the Conglomerate Merger, 13 Wm. \& Mary L. Rev. 623 (1972), http://scholarship.law.wm.edu/wmlr/vol13/iss3/5.

BLANCO, Luis Ortis, e ALFONSO, Lamadrid Plabo. 2011. "EU Competition Law Enforcement: Elements for a Discussion on Effectiveness and Uniformity". Fordham 38th Conference on International Antitrust Law and Policy 104 (setembro). http://antitrustlair.files.wordpress.com/2011/09/ortiz-lamadrid_european-comp-1enforcement.pdf.

BRUNA, Sérgio Varella. 1997. O Poder Economico E a Conceituacao Do Abuso Em Seu Exercicio. Editora Revista dos Tribunais.

BLOIS, K. J. 1999. "Vertical quasi-integration". In: BUCKLEY, Peter; MICHIE, Jonathan. Firms, organizations and contracts. New York: Oxford University Press.

BORK, Robert H.. 1993. The Antitrust Paradox: a policy at war with itself. New York: The Free Press. 
BRUNA, Sergio. 2001. O poder econômico e a conceituação do abuso em seu exercício. São Paulo: RT.

BUCKLEY, Peter J.; CASSON, Mark. 1999. "Joint ventures." In: BUCKLEY, Peter; MICHIE, Jonathan. Firms, organizations and contracts. New York: Oxford University Press.

BUCKLEY, Peter; MICHIE, Jonathan. 1999. "Introduction". In: BUCKLEY, Peter; MICHIE, Jonathan. Firms, organizations and contracts. New York: Oxford University Press.

CASTELLS, Manuel. 2002. A Sociedade em Rede. Paz e Terra. São Paulo.

COASE, R.H. 1988. The firm, the market and the law. Chicago: The University of Chicago Press.

COASE, Ronald H.1999. "The nature of the firm”. In: BUCKLEY, Peter; MICHIE, Jonathan. Firms, organizations and contracts. New York: Oxford University Press.

COMPARATO FábioK.. 1985. Estados, empresa e função social. São Paulo: Ed. RT 732/38. 1990. Direito Empresarial - estudos e pareceres. São Paulo: Saraiva.

COMPARATO, Fábio K; SALOMÃO FILHO, Calixto. 2014. O poder de controle na sociedade anônima. 6 ed. Rio de Janeiro: Ed. Forense.

CONTRACTOR, Farok e LORANGE, Peter. 2002. The growth of alliances in the knowledge-based economy. International Business Review 11 (2002) 485-502. Disponível em: file:///Users/deborahcaixeta/Downloads/0deec52acd297aa625000000.pdf .

CORDEIRO, António Menezes. 2012. Direito Comercial, Coimbra: Almedina.

CHANG, Howard, David Evans, e Richard Schmalensee. 2003. "Has the Consumer Harm Standard Lost its Teeth?" SSRN Scholarly Paper ID 332021. Rochester, NY: Social Science Research Network. http://papers.ssrn.com/abstract=332021.

CHINAGLIA, Olavo Z. 2010. "Poder de controle, influência significativa e influência relevante: breves anotações sobre a interface entre o Direito Societário e o Direito da Concorrência" em : CASTRO, Rodrigo R. Monteirode; MOURA AZEVEDO, Luis Andre N. de (Coord.). Poder de Controle e Outros Temas de Direito Societário e Mercado de Capitais. São Paulo: Quartier Latin.

CHRISTIANSEN, Arndt. 2006. "The 'more economic approach" in EU merger control: A critical assessment". Research Notes 21e. Deutsche Bank Research. http://ideas.repec.org/p/zbw/dbrrns/21e.html.

COOPER, James, Luke Froeb, Daniel O'Brien, e Michael Vita. 2005. "Vertical Restrictions and Antitrust Policy: What about the Evidence?" SSRN Scholarly Paper ID 825089. Vanderbilt Public Law Research Paper No. 05-32. Rochester, NY: Social Science Research Network. http://papers.ssrn.com/abstract=825089.

DORE, Ronald. 1999. "Goodwill and market capitalism". In: BUCKLEY, Peter; MICHIE, Jonathan. Firms, organizations and contracts. New York: Oxford University Press. 
ELHAUGE, Einer. 2003. "Defining Better Monopolization Standards". Stanford Law Review 56 (2) (agosto 29): 253-344.

EILMANSBERGER, T. 2005. "How to distinguish good from bad competition under Article 82 EC In search of clearer and more coherent standards for anti-competitive abuses". Common market law review 42 (1): 129-177.

EASTERBROOK, Frank H. 1984. "Limits of Antitrust”. Texas Law Review 63 (1): 1-40.

FORGIONI, Paula. 2011. Teoria Geral dos Contratos Empresariais. São Paulo: Revista dos Tribunais.

FRANÇA, Erasmo Valladão Azevedo e Novaes. 2013. A Sociedade em comum. São Paulo: Malheiros.

FRAZÃO. Ana. 2015. Joint ventures contratuais [mimeo]. 2015a. Direito concorrencial das estruturas [mimeo].

GELLHORN, Ernest; MILLER, W. Todd. 1997. "Competitor collaboration guidelines--a recommendation". Antitrust Bulletin;Winter 1997, Vol. 42 Issue 4, p851. Disponível em: http://connection.ebscohost.com/c/articles/254429/competitor-collaboration-guidelinesrecommendation .

GERARD, Damien. 2012. "The Effects-Based Approach Under Article 101 TFEU and its Paradoxes: Modernisation at War with Itself?" SSRN Scholarly Paper ID 2117780. Rochester, NY: Social Science Research Network. http://papers.ssrn.com/abstract=2117780.

GORMSEN, Liza Lovdahl. 2010. A Principled Approach to Abuse of Dominance in European Competition Law. 1o ed. Cambridge University Press.

HAGEDOORN, John. 1993. "Understanding the rationale for strategic technology partnering: interorganizational modes of cooperation and sectoral differences". In Strategic Management Journal. Vol 4 p. 371 a 385. Disponível em: http://arnop.unimaas.nl/show.cgi?fid=1705 .

HART, Oliver. 1999. “An economist's perspective on the theory of the firm”. In: BUCKLEY, Peter; MICHIE, Jonathan. Firms, organizations and contracts. New York: Oxford University Press.

HART, Oliver; TIROLE, Jean. 1990. "Vertical Integration and Market Foreclosure". In: HART, Oliver; TIROLE, Jean; WILLIAMSON, Oliver E. Brookings Papers on Economic Activity. Microeconomics. Brookings Institution Press. Vol. 1990, (1990), pp. 205-286.

HOVENKAMP. Hebert. 2002. "The Reckoning of post-Chicago Antitrust". In Post-Chicago Developments in Antitrust Law, 1-33. Edward Elgar Publishing. Group. 2005. Federal Antitrust Policy: The Law of Competition and Its Practice. 3o ed. West 2008. The Antitrust Enterprise: Principle and Execution. Harvard University Press. 
2010. "The Harvard and Chicago Schools and the Dominant Firm". SSRN Scholarly Paper ID 1014153. U Iowa Legal Studies Research Paper No. 07-19. Rochester, NY: Social Science Research Network. http://papers.ssrn.com/abstract=1014153.

2014. "Robert Bork and vertical integration: leverage, foreclosure, and efficiency". Antitrust Law Journal No. 3 Vol. 79.

IMAI, Ken-Ichi; ITAMI, Hiroyuki. 1999. "Interpenetration of organization and market: Japan's firm and market in comparison with the US. In: BUCKLEY, Peter; MICHIE, Jonathan. Firms, organizations and contracts. New York: Oxford University Press.

LOPATKA, John E., e William H. Page. 2004. "Economic Authority and the Limits of Expertise in Antitrust Cases". Cornell Law Review 90: 617.

KAPLOW, Louis. 2010. "Why (Ever) Define Markets”. Harvard Law Review 124: 437.

KAPLOW, Louis, e SHAPIRO, Carl. 2007. “Antitrust”. SSRN Scholarly Paper ID 961264. Harvard Law and Economics Discussion Paper No. 575. Rochester, NY: Social Science Research Network. http://papers.ssrn.com/abstract $=961264$.

KISHOR, Vidyullatha. 2012. Comparative Merger Control Regulationslessons From Eu And Us. 5 th year, B.A.L.LB. West Bengal National University of Juridical Sciences. http://cci.gov.in/images/media/ResearchReports/VidyullathaKishor30jan2012.pdf.

KORAH, Valentine. 2000. An Introductory Guide to EEC Competition Law and Practice. Seventh Edition. Oxford: Hart Publishing.

LOWE, Philip. 2008. "The design of competition policy institutions for the 21st century: The Experience of the European Commission and DG Competition". Competition policy newsletter (3): 1-11.

MARITI, P. e SMILEY, R.H. 1999. "Co-operative agreements". In: BUCKLEY, Peter; MICHIE, Jonathan. Firms, organizations and contracts. New York: Oxford University Press.

MCFALLS, Michael S. 1998. "The Role and Assessment of Classical Market Power in Joint Venture Analysis". Antitrust Law Journal, Vol. 66, pp. 651-735.

MENDES, Francisco Schertel. 2013. O controle de condutas no direito concorrencial brasileiro: características e especificidades. Universidade de Brasília. Dissertação de mestrado.

MILES, Raymond E., SNOW, Charles C. 1999. "Organizations: new concepts for new forms." In: BUCKLEY, Peter; MICHIE, Jonathan. Firms, organizations and contracts. New York: Oxford University Press.

MILGRON, Paul, ROBERTS, John. 1999. "Economic Theories of the Firm. In: BUCKLEY, Peter; MICHIE, Jonathan. Firms, organizations and contracts. New York: Oxford University Press.

MORAIS, Luis Domingos Silva. 2006. Empresas Comuns - joint ventures - no Direito Comunitário da Concorrência. Coimbra: Almedina. 
MOTTA, Massimo. 2004. Competition Policy: Theory and Practice. Cambridge University Press.

PFEFFER, Jeffrey; NOWAK, Philip. 1999. "Joint Ventures and Interdependence". In: BUCKLEY, Peter; MICHIE, Jonathan. Firms, organizations and contracts. New York: Oxford University Press.

PINHEIRO, Luís de Lima. 2003. CONTRATO DE EMPREENDIMENTO COMUM - JOINT Venture - em Direito InTernacional Privado. Coimbra: Almedina.

PITOFSKY, Robert. 1979. "The Political Content of Antitrust". University of Pennsylvania

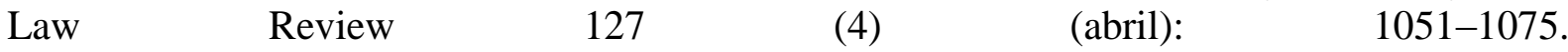
http://scholarship.law.upenn.edu/cgi/viewcontent.cgi?article=4867\&context=penn_law_revie w.

RIBEIRO, Márcia Carla Pereira; GALESKI JUNIOR, Irineu. 2009. Teoria Geral dos Contratos. Contratos empresariais e análise econômica. Rio de Janeiro: Elsevier.

RICHARDSON, G. B. 1999. "The Organization of Industry". In: BUCKLEY, Peter; MICHIE, Jonathan. Firms, organizations and contracts. New York: Oxford University Press.

SLOT, Piet Jan, e Angus Johnston. 2006. An Introduction to Competition Law. 1st English Ed. Hart Publishing.

SHAPIRO, Carl. 1996. "Mergers with differentiated products". Articles and Features. Spring 1996. pp. 23 a 30. Disponível em: http://faculty.haas.berkeley.edu/shapiro/diversion.pdf.

WERDEN, Gregory J. \& FROEB, Luke M.. 1994. The Effects of Mergers in Differentiated Products Industries: Logit Demand and Merger PolicyJLEO (1994) 10 (2): 407-426. Disponível em: http://jleo.oxfordjournals.org/content/10/2/407.full.pdf .

WELLER, Charles. 1999. A "new" rule of reason from Justice Brandeis' "concentric circles" and other changes in law. The antitrust bulletin : the journal of American and foreign antitrust and trade regulation.- Federal Legal Publications, ISSN 0003-603x, ZDB-ID 2801164. - Vol. 44.1999, 4, p. 881-957.

WILLIANSON, Oliver E. 1985. The Economic Institutions Of Capitalism Firms, Markets ,Relational Contracting. China Social Sciences Publishing House Chengcheng Books Lill.. Free Press. Disponível em: http://nkuie.org/wpcontent/uploads/2013/03/\%E8\%B5\%84\%E6\%9C\%AC\%E4\%B8\%BB\%E4\%B9\%89\%E7\%B В\%8F\%Е6\%B5\%8Е\%Е5\%88\%B6\%Е5\%BA\%A6\%Е5\%A8\%81\%Е5\%BB\%89\%Е5\%A7\%8 6\%Е6\%A3\%AE\%E8\%8B\%B1\%E6\%96\%87.pdf .

1999. "Transaction-cost economics: the governance of contractual relations". In:

BUCKLEY, Peter; MICHIE, Jonathan. Firms, organizations and contracts. New York: Oxford University Press.

\section{LEGISLAÇÕES E JURISPRUDÊNCIA CONSULTADAS}


BRASIL. Lei $\mathbf{n}^{\mathbf{0}}$ 12.529, de 30 de novembro de 2011. Estrutura o Sistema Brasileiro de Defesa da Concorrência; dispõe sobre a prevenção e repressão às infrações contra a ordem econômica; altera a Lei $\mathrm{n}^{\circ}$ 8.137, de 27 de dezembro de 1990, o Decreto-Lei $\mathrm{n}^{\circ} 3.689$, de 3 de outubro de 1941 - Código de Processo Penal, e a Lei n ${ }^{0}$ 7.347, de 24 de julho de 1985; revoga dispositivos da Lei $n^{0} 8.884$, de 11 de junho de 1994, e a Lei $n^{0} 9.781$, de 19 de janeiro de 1999; e dá outras providências.. Disponível em: http://www.planalto.gov.br/ccivil_03/_Ato2011-2014/2011/Lei/L12529.htm. Acesso em: 15 maio 2012.

Ato de Concentração $n^{\circ}$ 08012.002870/2012-38. Requerentes: Monsanto do Brasil Ltda. e Syngenta Proteção de Cultivos Ltda. Relator: Marcos Paulo Veríssimo. Julgado em 28.08.2013.

Ato de Concentração $\mathrm{n}^{\circ}$ 08012.006706/2012-08 Requerentes: Monsanto do Brasil Ltda. e Nidera Sementes Ltda. Relator: Alessandro Octaviani. Julgado em 28.08.2013.

Ato de Concentração $\mathrm{n}^{\circ}$ 08700.003898/2012-34 Requerentes: Monsanto do Brasil Ltda. e Cooperativa Central de Pesquisa Agrícola Relator: Alessandro Octaviani. Julgado em 28.08.2013.

Ato de Concentração n ${ }^{\circ}$ 08700.003937/2012-01 Requerentes: Monsanto do Brasil Ltda. e Don Mario Sementes Ltda. Relator: Alessandro Octaviani. Julgado em 28.08.2013.

Ato de Concentração no 08012.010293/2004-48. Requerentes: Ideiasnet S.A. e Flynet S.A. Relator:Luis Alberto Esteves. Julgado em 26.01.2006.

Ato de Concentração 08012.011058/2005-74. Requerentes: Holcim S.A. e Camargo Correa. Relator: Paulo Furquim de Azevedo. Julgado em 20.07.2006.

Consulta $n^{\circ}$ 08700.003674/2007-65. Consulente: Fujimilf da Amazônia Ltda. Relator: Luís Delorme Prado. Julgado em 13.03.2008.

Ato de Concentração 08012.000182/2010-71. Requerentes: Ilharabras S/A Indústrias Químicas e Monsanto do Brasil Ltda. Relator: Ricardo Ruiz. Julagdo em 17.03.2010.

Ato de Concentração no 08012.010293/2004-48. Requerentes: Ideiasnet S.A. e Flynet S.A. Relator:Luis Alberto Esteves. Julgado em 26.01.2006.

Ato de Concentração $\mathrm{n}^{\mathrm{o}}$ 08700.009957/2013-69. Requerentes: Raízen Energia S.A. e Novozymes A/S. Aprovado sumariamente pela Superintendência-Geral em 13.12.2013.

\section{DOCUMENTOS OFICIAIS CONSULTADOS}

OECD. Why is competition important for growth and poverty reduction?. Department for International Development . Global Forum on Investment. Londo, March 2008. Disponível em: http://www.oecd.org/fr/. Acesso em: 17 de agosto 2012.

Organização para o desenvolvimento e Cooperação Econômica (“OCDE”) e Banco Mundial. 2003. Diretrizes para elaboração de política de defesa da concorrência. Rio de Janeiro: Ed. Singular. 
Regulamento CE no 139/2004 DO CONSELHO de 20 de Janeiro de 2004 relativo ao controlo das concentrações de empresas («Regulamento das concentrações comunitárias». Publicado no Jornal Oficial da União Europeia L 24/1 de 29.1.2004. 